\title{
Stratigraphy, age, composition, and correlation of late Quaternary tephras interbedded with organic sediments in Waikato lakes, North Island, New Zealand
}

\author{
D. J. LOWE \\ Department of Earth Sciences \\ University of Waikato \\ Private Bag \\ Hamilton, New Zealand
}

\begin{abstract}
Cores from 14 peaty lakes in the central Waikato region, northern North Island, contain a sequence of 41 well-preserved, mainly macroscopic, occasionally bedded, ash and lapilli layers ranging in thickness from c. 2 to $110 \mathrm{~mm}$ and interbedded with fine-grained organic lake sediment. The layers, whose field and compositional properties are described in detail, are distal airfall tephras that were erupted between c. 17000 and c. $1800{ }^{14} \mathrm{C}$ years ago from six rhyolitic and andesitic volcanic centres located c. $70-200 \mathrm{~km}$ from the Waikato sites: Taupo (5 tephras), Okataina (7), Maroa (1) (rhyolitic); Mayor Island (2) (peralkaline); Tongariro (11), and Egmont (15) (andesitic).

These sources were distinguished using the tephras' mineralogical assemblages and glass and mineral compositions (determined by electron microprobe). The tephras were correlated with named proximal eruptives using their stratigraphic relationships and radiometric ages (based on multiple ${ }^{14} \mathrm{C}$ dates on enclosing lake sediment) in combination with the mineralogical and chemical criteria. The correlated tephras associated with each source (listed youngest to oldest) are: TaupoTaupo, Mapara, Whakaipo, Hinemaiaia, Opepe; Okataina-Whakatane, Mamaku, Rotoma, Waiohau, Rotorua, Rerewhakaaitu, Okareka; Maroa-Puketarata; Mayor Island-Tuhua, uncorrelated; Tongariro-Mangamate (?Te Rato Lapilli), Okupata (8 informal units Oa-1 to Oa-8), uncorrelated, Rotoaira; and $E$ gmont -15 informal units Eg-1 to Eg-15.
\end{abstract}

Received 6 May 1987, accepted 23 December 1987
In total, the post c. 15000 year lacustrine tephras range in thickness from c. $20 \mathrm{~cm}$ (possibly equivalent to c. $37 \mathrm{~cm}$ on dry land because of compaction or dissemination in the lakes) in the north of the study area, to c. $25 \mathrm{~cm}$ (c. $47 \mathrm{~cm}$ on dry land) in the south, to c. $42 \mathrm{~cm}$ (c. $78 \mathrm{~cm}$ on dry land) in the east. Of these total thicknesses, rhyolitic tephras make up c. 65-95\%; andesitic tephras are more common in the south (c. 30-35\%), decreasing markedly to the north (c. 10-15\%) and east (c. 5\%). These different proportions of andesitic to rhyolitic material may have influenced weathering and argillisation in the tephra-derived soils in the Waikato area.

Provisional isopach maps for 11 tephras (Whakaipo, Eg-2, Tuhua, Mamaku, Rotoma, Opepe, Mangamate, Waiohau, Oa-8, Rotorua, and Rerewhakaaitu) are presented. The thickness resolution of these is generally one to two orders of magnitude greater than in most previous isopach maps in New Zealand, and attests to the value of using lake sediments for tephra mapping. Most of the tephras found in the Waikato lakes should persist well beyond the Waikato area. Extrapolated plots of isopach thickness against distance from isopach centre suggest that c. $1 \mathrm{~mm}$ isopachs should occur c. $200-300 \mathrm{~km}$ from source. Many of the tephras were probably emplaced by powerful eruptions (possibly including directed blasts), or were dispersed by strong winds, or both. Co-ignimbrite ash may have contributed to some of the resulting lacustrine tephra deposits.

The 41 tephras identified in the Waikato lake cores record, on average, an eruptive event every c. 400 years (rhyolitic, 1 per c. 1100 years; andesitic, 1 per c. 650 years). The tephras, particularly Taupo, Tuhua, Mamaku, Opepe, Mangamate, Waiohau, Rotorua, Rerewhakaaitu, and Okareka, are useful as time-stratigraphic markers in paleoenvironmental studies on the lakes and catchments.

Keywords stratigraphy; late Quaternary; tephrostratigraphy; tephrochronology; correlation; composition; C-14; absolute age; isopach maps; North Island; volcanoes; Waikato; lakes; paleolimnology; "Tirau Ash"; "Mairoa Ash" 


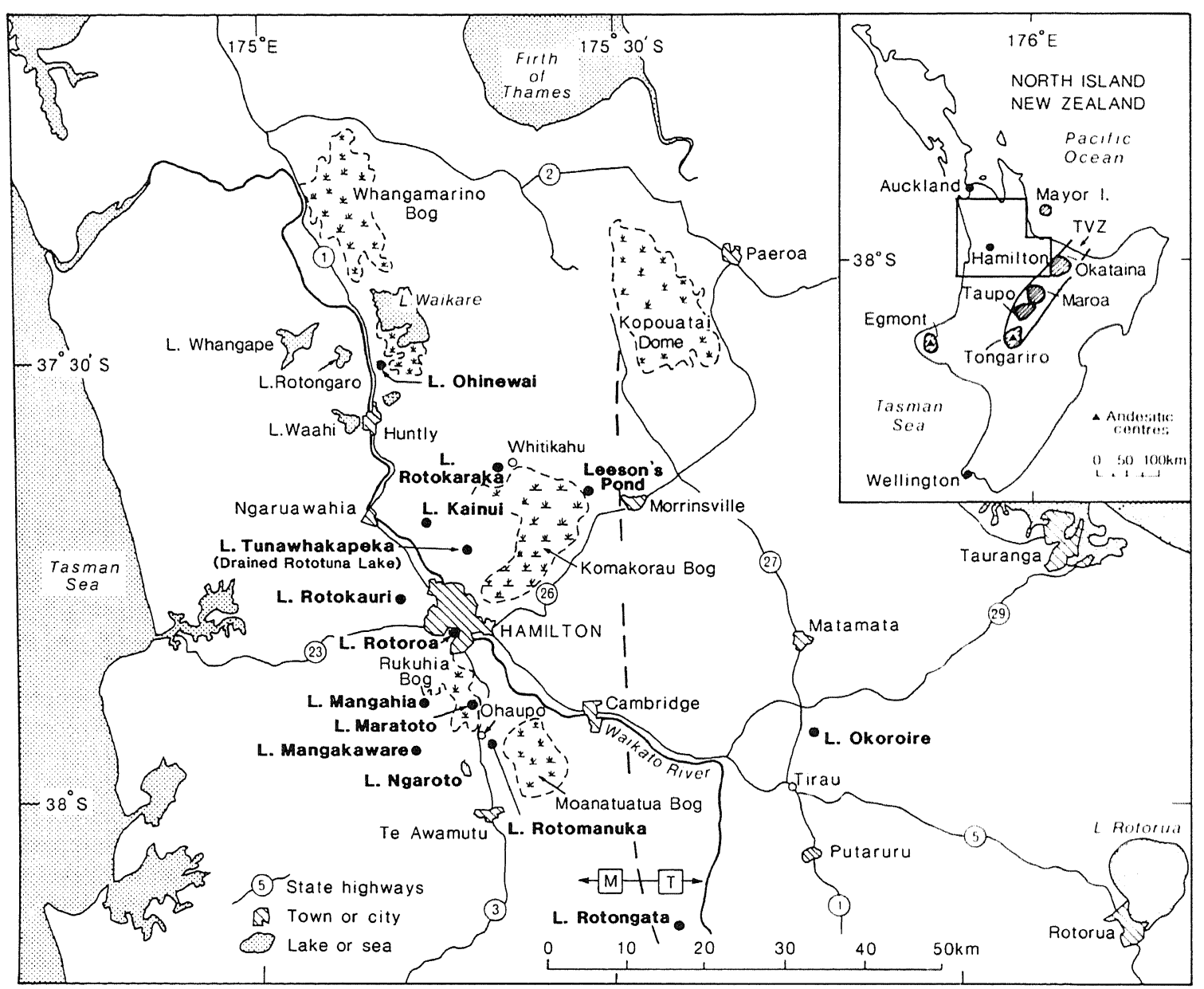

Fig. 1 The Waikato area showing the locations of the lakes cored in this study (bold). Some other lakes and peat bogs are also shown. The dashed line marks the approximate boundary of the two main soil-forming materials described in early soil surveys as "Mairoa Ash" (M) and "Tirau Ash" (T) (after N.Z. Soil Bureau 1954). The inset shows the locations of tephra-producing rhyolitic and andesitic volcanic centres active in the late Quatemary period (after Cole \& Naim 1975 and Hogg \& McCraw 1983). TVZ = Taupo Volcanic Zone.

\section{INTRODUCTION}

The central Waikato region is well to the north and northwest of the main tephra-producing volcanoes of central North Island (Fig. 1; McCraw 1975). Consequently, most of the late Quaternary airfall tephra deposits found there are relatively thin and have been hard to differentiate. Early reconnaissance mapping of the tephras, chicfly for soil survey purposes, separated two main soil-forming materials which were named Mairoa Ash and Tirau Ash (Grange 1931; Grange \& Taylor 1932; Taylor 1933; Grange et al. 1939; N.Z. Soil Bureau 1954). Although each of these deposits was believed to be composed of materials derived from several eruptions, they were arbitrarily named "Ash", rather than "Ashes" or "Ash Beds", for purposes of soil description and classification (Gibbs et al. 1982). Tirau Ash, considered to be primarily but not wholly rhyolitic, formed the parent material of soils in eastern parts of the Waikato; Mairoa Ash, thought to contain a greater component of andesitic ash beds of an intermittent origin, extended westward from the Tirau Ash boundary to the west coast (Fig. 1). Taupo Pumice was recognised in soil profiles as far north as Putaruru (Grange \& Taylor 1932), and as a discrete lapilli layer near the surface of the Rukuhia and Moanatuatua peat bogs (Grange et al. 1939; Tonkin 1967). 
More recent studies on stratigraphic sections and soil profiles in the Waikato and adjoining districts (Pullar 1967, 1978; Vucetich \& Pullar 1969; Pullar \& Birrell 1973a, b; Pullar et al. 1973; Hodder \& Wilson 1976; Lowe 1979, 1981a; Orbell 1982; Parfitt et al. 1982a) confirmed the composite nature of the Mairoa Ash and Tirau Ash, and identified some of the tephras making up the deposits at a number of sites. These identifications were achieved either by careful hand-over-hand field methods (e.g., Vucetich \& Pullar 1969; Pullar \& Birrell 1973b), or by mineralogical and geochemical methods based on laboratory analyses (e.g., Hodder \& Wilson 1976; Lowe 1981a; see also Hogg \& McCraw 1983).

Both these approaches have limitations, however. The chief difficulties in the field arise from the loss of identifying characteristics as individual tephras thin away from source towards the Waikato area, collapsing into composite beds (Pullar 1967), and from the masking effects of postdepositional erosion, mixing, and weathering in the soil-forming environment. In the laboratory, detailed grain-bygrain "fingerprinting" methods circumvented these problems to some extent, but relatively few tephras were identified with certainty.

An additional complication has been the necessity to consider the proposal that loess contributed significantly to the surficial deposits in some parts of the region (McCraw 1967; Vucetich 1968; Cowie \& Milne 1973). However, this proposal was largely discounted by Lowe (1981a).

The obtaining of a $3.2 \mathrm{~m}$ long sediment core from Lake Maratoto, a small peaty lake near Ohaupo (Fig. 1), heralded a new approach to elucidating the late Quaternary tephrostratigraphy of the Waikato area. The core contained a succession of multiple, essentially unweathered, discrete tephra layers separated from one another by fine-grained organic lake sediment (Lowe et al. 1980). Most of the tephras, aged $\leq$ c. 15000 years*, were identified (some tentatively) by their dominant ferromagnesian mineralogy, their stratigraphic position, and by five radiocarbon dates (the first to be obtained on airfall tephras in the Hamilton Basin). Lowe et al. (1980) showed that some of the tephras were derived from Mayor Island, Tongariro, and possibly Mt Egmont sources in addition to Okataina and Taupo Volcanic Centres (Fig. 1,

*All ages reported and discussed in the text are conventional radiocarbon ages based on the Libby (old) half-life of 5568 years (Hogg et al. 1987). inset). The core thus revealed that "Mairoa Ash" in the Ohaupo area was likely to comprise many more tephras than had previously been considered present, and that these were derived from a variety of North Island volcanic centres (Lowe 1981b).

Since this first core was taken from Lake Maratoto, a further 13 lakes, and several peat bogs, in the Waikato region have been cored (Fig. 1) to give a wider picture of tephra occurrence and distribution. The initial findings of Lowe et al. (1980) for Lake Maratoto were partly modified (some tephras were re-identified) and further cores examined in more detail by Green \& Lowe (1985). Some analyses of cores from other Waikato lakes have been reported by Lowe et al. (1981), Lowe (1986a, b), and Hogg et al. (1987).

The primary aim of this paper is to document the field properties, stratigraphy, chronology, and composition of the late Quaternary tephras contained in sediments in cores from the lakes in the central Waikato region. The lacustrine tephras described and analysed range in age from c. 1800 to 17000 years B.P., and were erupted from six volcanic centres of both rhyolitic and andesitic composition (Fig. 1). The tephras are identified and correlated with named eruptive units elsewhere by using their stratigraphic relationships and radiometric ages in combination with mineralogical and chemical criteria. New isopach maps are presented, and the pattern of distribution of the tephras and their emplacement mechanisms are also considered.

The use of such lake sediments or peats to erect a comprehensive tephrostratigraphy is unusual, and the Waikato lakes have provided the longest and most complete sequence of tephras yet investigated in New Zealand lakes or bogs (cf. Topping \& Kohn 1973; Howorth et al. 1980; McGlone 1983; Lowe \& Hogg 1986). Apart from Iceland (e.g., Thorarinsson 1981), studies specifically on tephras in bogs and lakes elsewhere have also been relatively sparse, particularly from sites containing more than just a few tephras, but they are becoming increasingly important (e.g., Borchardt et al. 1973; Westgate 1977; Davis 1985; Riehle 1985).

\section{WAIKATO LAKES AND BOGS}

Most of the small, typically peaty lakes in the central Waikato region originated c. 15 000-17 000 years ago, during the final stages of alluvial aggradation of the Hinuera Formation by the ancestral Waikato 
River (McCraw 1967; Green \& Lowe 1985; Lowe \& Green 1987). The lakes were formed when antecedent valleys draining low Pleistocene hills were blocked by the volcaniclastic Hinuera deposits, which dammed the valley mouths. The lakes are shallow $(<\mathrm{c} .8 \mathrm{~m})$ and usually contain $\mathrm{c}$. 3-4 m (occasionally 5-6 m) of soft, brownish-black (peaty) to olive-grey lacustrine muds or clays (known as dy or gyttja) containing the remains of small lake-dwelling plants and animals (Green 1979; Boubée 1983). They have low sedimentation rates (c. 0.1-0.2 mm/year) (Green \& Lowe 1985). Occasionally vivianite is found in the sediments.

The subsequent development of many of these lakes was affected by the massive growth of large, $c$. 10-12 $\mathrm{m}$ deep ombrogenous peat bogs on the surface of the Hinuera sediments (Fig. 1; Davoren 1978). These bogs probably formed first in patches in swampy hollows and around the margins of shallow lakes (such as Lake Maratoto) on the Hinuera surface (McCraw 1967). They rapidly expanded and deepened after c. 10000-12000 years ago, probably in response to a net increase in rainfall and hence a rise in regional water tables (Green \& Lowe 1985).

The record of tephra fallout provided by the Waikato lakes is more comprehensive than that of the adjacent peat bogs. Usually only about six disseminated tephras, chiefly from substantial rhyolitic eruptions, are detectable in the peat cores*. For tephrostratigraphic purposes, the lakes are advantageous in that:

(1) they are older and contain a longer record;

(2) they have soft, fine sediment and (in the deeper basins) a relatively undisturbed environment that has allowed the preservation, as separate units, of deposits only a few millimetres in thickness; and

(3) the continuous lake cores provide unequivocal stratigraphic control.

Nevertheless, the tephrostratigraphy of the peat bogs is useful where lakes are lacking, especially in mapping and dating tephras not otherwise identifiable in subaerial environments (e.g., Hogg \& McCraw 1983). The results of the peat coring are excluded from this paper, but some preliminary findings are given in Green \& Lowe (1985) and Hogg et al. (1987).

\section{CORING SITES AND METHOD}

Locations of the lakes cored in this study are shown in Fig. 1. Around 80 cores, usually c. $2-4 \mathrm{~m}$ in length, were obtained from the lakes with a handoperated, modified Livingstone piston sampler (after Rowley \& Dahl 1956). The coring tubes comprised lengths of PVC pipe of $50 \mathrm{~mm}$ internal diameter that were previously sawn in half longitudinally and held together with waterproof plastic tape. After the coring operation, the cores were split longitudinally using fine wire. Normally, several cores were taken from each lake, usually from the deepestareas, but occasionally from sites in shallower water or at the shoreline.

\section{STRATIGRAPHY AND FIELD PROPERTIES OF THE TEPHRAS}

The stratigraphy and main field properties of the tephras in the lake cores are summarised in Table 1 and Fig. 2. The stratigraphic sequence, thickness, lithology, and bedding characteristics of the tephra layers are practically identical in all of the lakes examined, hence they are regarded as representing primary airfall tephras. Further support for an airfall origin is given by Lowe (1985) in that the tephras in Lake Maratoto, although uneven in thickness, are

\footnotetext{
*These include Taupo, Mamaku, Rotoma, Waiohau, and Rotorua tephras in the Hamilton Basin and, additionally, Kaharoa and Whakatane tephras in the Matamata Basin (Lowe 1987).
}

(Notes to Table 1)

* References for definitions of Taupo, Okataina, and Maroa derived correlative tephras are: Healy (1964); Vucetich \& Pullar (1964, 1969, 1973); Lloyd (1972); Froggatt (1981c, d).

†Group-Subgroup designations: 1 = Lake Taupo Group, Taupo Subgroup; 2 = Okataina Group, Rotorua Subgroup (Howorth et al. 1981); $3=$ no formal group status. Tuhua Tephra Formation was defined by Hogg \& McCraw (1983); it is probably equivalent to the Oira Pyroclastite Formation (Mayor Island Group) of Buck et al. (1981), which applies to deposits on Mayor Island only; 4 = Tongariro Subgroup (Topping 1973).

†Some ages interpolated from sedimentation rates (see text and Fig. 6).

anformally named Egmont derived tephras.

befinition of Froggatt (1981c) and Lowe (1986a).

'Possibly Te Rato Lapilli member (symbol Tt) (Lowe et al. 1980).

"Members of Okupata Tephra Formation informally designated Oa-1 to Oa-8; last is tentatively correlated with the "basal lapilli" unit of Topping (1973) (see text). 
Table 1 Composite stratigraphic column of late Quaternary tephras identified in cores fromWaikato lakes. Some identifications are provisional.

\begin{tabular}{|c|c|c|c|c|}
\hline $\begin{array}{l}\text { Tephra and symbol } \\
\text { (see Fig. 2)* }\end{array}$ & Source & $\begin{array}{l}\text { Group- } \\
\text { Subgroup } \dagger\end{array}$ & $\begin{array}{c}\text { Age } \\
\text { (years B.P., } \\
\text { old T } 1 / 2) \ddagger\end{array}$ & $\begin{array}{l}\text { General description and approximate thickness range; } \\
\text { comments }\end{array}$ \\
\hline Taupo Pumice, Tp & Taupo & 1 & 1800 & Yellowish fine lapilli \& coarse ash, 5-50 mm thick \\
\hline Mapara Tephra, Mp & Taupo & 1 & 2200 & White fine ash, $2-3 \mathrm{~mm}$ \\
\hline Egmont-1, Eg-1 ${ }^{\mathrm{a}}$ & Egmont & - & 2500 & Grey fine-medium ash, $3-5 \mathrm{~mm}$ \\
\hline Whakaipo Tephra, Wo & Taupo & 1 & 2800 & Greyish-white fine ash, $2-10 \mathrm{~mm}$ \\
\hline Egmont-2, Eg-2 & Egmont & - & 3700 & $\begin{array}{l}\text { Brownish-grey, slightly speckled medium-coarse ash, } \\
\text { 3-5 mm }\end{array}$ \\
\hline Egmont-3, Eg-3 & Egmont & - & 3750 & Indistinct fine ash, 1-2 mm (found only in L. Okoroire) \\
\hline Egmont-4, Eg-4 & Egmont & - & 4100 & Dark, medium-coarse ash, $1-3 \mathrm{~mm}$; blotchy \\
\hline Egmont-5, Eg-5 & Egmont & - & 4400 & $\begin{array}{l}\text { Pale yellowish-white, brownish-speckled, fine-medium } \\
\text { ash, 3-6 mm }\end{array}$ \\
\hline Hinemaiaia Tephrab ${ }^{b}, \mathrm{Hm}$ & Taupo & 1 & 4500 & White fine ash, $1-8 \mathrm{~mm}$ \\
\hline Whakatane Ash, Wk & Okataina & 2 & 4800 & $\begin{array}{l}\text { White fire-medium ash, } 10-12 \mathrm{~mm} \text { in L. Okoroire; } \\
\text { possibly microscopic in other lakes }\end{array}$ \\
\hline Egmont-6, Eg-6 & Egmont & - & 5250 & Yellow fine ash, $2-3 \mathrm{~mm}$ \\
\hline Egmont-7, Eg-7 & Egmont & - & 5850 & Greyish-brown fine-medium ash, 1-2 mm \\
\hline Egmont-8, Eg-8 & Egmont & $\bar{a}$ & 5900 & Indistinct pale yellow fine ash, 1-2 mm \\
\hline Tuhua Tephra, Tu & Mayor Is. & 3 & 6200 & Olive, greenish-grey fine-coarse ash, $5-45 \mathrm{~mm}$ \\
\hline Mamaku Ash, Ma & Okataina & 2 & 7000 & $\begin{array}{l}\text { Pale yellowish-brown to orange, fine-coarse ash, } 20-80 \\
\text { mm; usually bedded }\end{array}$ \\
\hline Rotoma Ash, Rm & Okataina & 2 & 8500 & Pale yellowish-white fine ash, 3-30 mm \\
\hline Opepe Tephra, Op & Taupo & 1 & 8900 & $\begin{array}{l}\text { Greyish fine ash, 10-20 mm (medium-coarse ash in } \\
\text { L. Okoroire) }\end{array}$ \\
\hline Egmont-9, Eg-9 & Egmont & - & 9300 & $\begin{array}{l}\text { Yellowish-white, speckled medium ash, 1-3 mm; may } \\
\text { be disseminated (c. } 10 \mathrm{~mm} \text { ); age approx. }\end{array}$ \\
\hline Egmont-10, Eg-10 & Egmont & - & 9600 & Yellowish medium ash, 1-2 mm; age approx. \\
\hline Mangamate Tephra, $\mathrm{Mm}^{\mathrm{c}}$ & Tongariro & 4 & 9950 & $\begin{array}{l}\text { Mainly greyish-black, white speckled base, coarse } \\
\text { ash, 5-20 mm; scoriaceous }\end{array}$ \\
\hline Okupata Tephra, Oa-1 ${ }^{d}$ & Tongariro & 4 & 10100 & Pale grey fine ash, $2-3 \mathrm{~mm}$ \\
\hline Egmont-11, Eg-11 & Egmont & - & 10100 & Pale grey fine ash, $2-3 \mathrm{~mm}$ \\
\hline Okupata Tephra, $\mathrm{Oa}-2$ & Tongariro & 4 & 10500 & Indistinct brownish fine-medium ash, $1-2 \mathrm{~mm}$; age approx. \\
\hline Okupata Tephra, $\mathrm{Oa}-3$ & Tongariro & 4 & 10800 & Indistinct brownish fine-medium ash, $1-2 \mathrm{~mm}$; age approx. \\
\hline Okupata Tephra, $\mathrm{Oa}-4$ & Tongariro & 4 & $11050)$ & Greyish-white, speckled, mainly medium-coarse ash but \\
\hline Egmont-12, Eg-12 & Egmont & - & $11050)$ & some fine ash $4-5 \mathrm{~mm}$ \\
\hline Okupata Tephra, Oa-5 & Tongariro & 4 & 11200 & $\begin{array}{l}\text { Pale greyish-white fine ash, } 2-3 \mathrm{~mm} \text {; age approx.; } \\
\text { contains traces of Eg-tephra(?) }\end{array}$ \\
\hline Okupata Tephra, Oa-6 & Tongariro & 4 & 11700 & $\begin{array}{l}\text { Yellowish fine ash, } 2-3 \mathrm{~mm} \text {; may be blotchy or } \\
\text { disseminated ( c. } 5-10 \mathrm{~mm} \text { ) }\end{array}$ \\
\hline Okupata Tephra, Oa-7 & Tongariro & $\bar{a}$ & 12100 & Indistinct brownish fine ash, $1 \mathrm{~mm}$; age approx. \\
\hline Waiohau Ash, Wh & Okataina & 2 , & 12200 & $\begin{array}{l}\text { White with cream top, fine-medium ash, } 10-45 \mathrm{~mm} \text {; } \\
\text { commonly bedded }\end{array}$ \\
\hline Okupata Tephra, Oa-8 ${ }^{d}$ & Tongariro & 4 & 12700 & $\begin{array}{l}\text { Greyish-brown to brown fine ash, } 5-20 \mathrm{~mm} \text {; } \\
\text { occasionally disseminated (c. } 50 \mathrm{~mm} \text { ) }\end{array}$ \\
\hline uncorrelated, un & Tongariro & 4 & 13100 & $\begin{array}{l}\text { Brownish-grey fine-coarse ash, } 3-5 \mathrm{~mm} \text {; occ. bedded; } \\
\text { age approx. }\end{array}$ \\
\hline Rotorua Ash, $\mathrm{Rr}$ & Okataina & 2 & 13300 & $\begin{array}{l}\text { White mainly coarse ash, } 15-110 \mathrm{~mm} \text {; distinctly } \\
\text { bedded (see Fig. 4) }\end{array}$ \\
\hline Rotoaira Lapilli, Rt & Tongariro & 4 & 13700 & $\begin{array}{l}\text { Greyish fine-medium ash, } 2 \mathrm{~mm} \text {; usually disseminated } \\
\text { (c. } 30 \mathrm{~mm} \text { ); age approx. }\end{array}$ \\
\hline Puketarata Ash, Pk & Maroa & - & 14000 & $\begin{array}{l}\text { Indistinct disseminated fine ash; contains traces } \\
\text { of } \mathrm{Eg} \text {-iephra(? ); age approx. }\end{array}$ \\
\hline Egmont-13, Eg-13 & Egmont & $\overline{2}$ & $14500)$ & Indistinct pale yellowish-brown fine to $\mathrm{v}$. fine ash; \\
\hline uncorrelated, un & Mayor Is. & 3 & $14500)$ & $\begin{array}{l}\text { Mayor Is. tephra occurs as glass only (micro- } \\
\text { scopic); ages approx. }\end{array}$ \\
\hline Rerewhakaaitu Ash, Rk & Okataina & 2 & 14700 & $\begin{array}{l}\text { White fine-coarse ash, wavy boundaries, } 5-30 \mathrm{~mm} \text {; } \\
\text { some biotite flakes visible }\end{array}$ \\
\hline Egmont-14, Eg-14 & Egmont & - & 15000 & Brownish, white-speckled coarse-medium ash, 1-2 mm \\
\hline Egmont-15, Eg-15 & Egmont & - & 15500 & Brown fine ash, $1 \mathrm{~mm}$; age approx. (see Fig. 6) \\
\hline Okareka Ash, Ok & Okataina & 2 & 17000 & $\begin{array}{l}\text { Yellowish-white fine ash over coarse ash, } 50 \mathrm{~mm} \text {; } \\
\text { biotite flakes common; age approx. }\end{array}$ \\
\hline
\end{tabular}




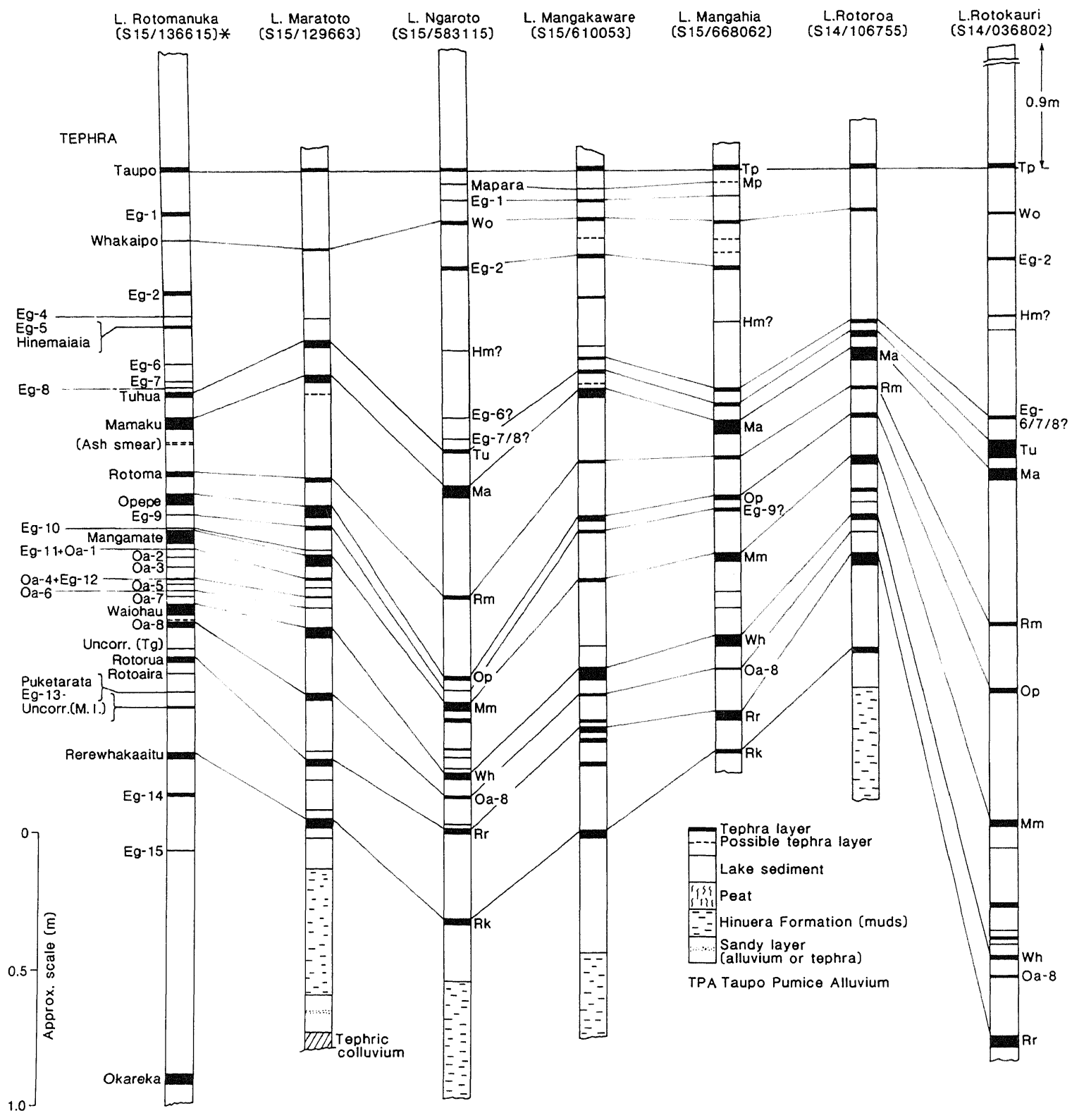

Fig. 2 Stratigraphy and correlation of late Quaternary tephras in cores from 14 Waikato lakes. Tephra names are explained in full in Table 1; Eg-1 to Eg-15 = Egmont derived tephras, informally numbered 1-15 with increasing age; Oa-1 to Oa-8 = informal units, numbered 1-8, of Okupata Tephra Formation; uncorr. = uncorrelated tephra $(\mathrm{Tg}=$ Tongariro source; M.I. = Mayor Island source). The chronology of the tephras is given in Fig. 6; additional ${ }^{14} \mathrm{C}$ dates given here (Wk- numbers) are in years B.P. The columns depicted are composites of two or more cores from each lake (hence scale is approximate because of differences in sediment thicknesses from core to core), as follows: 


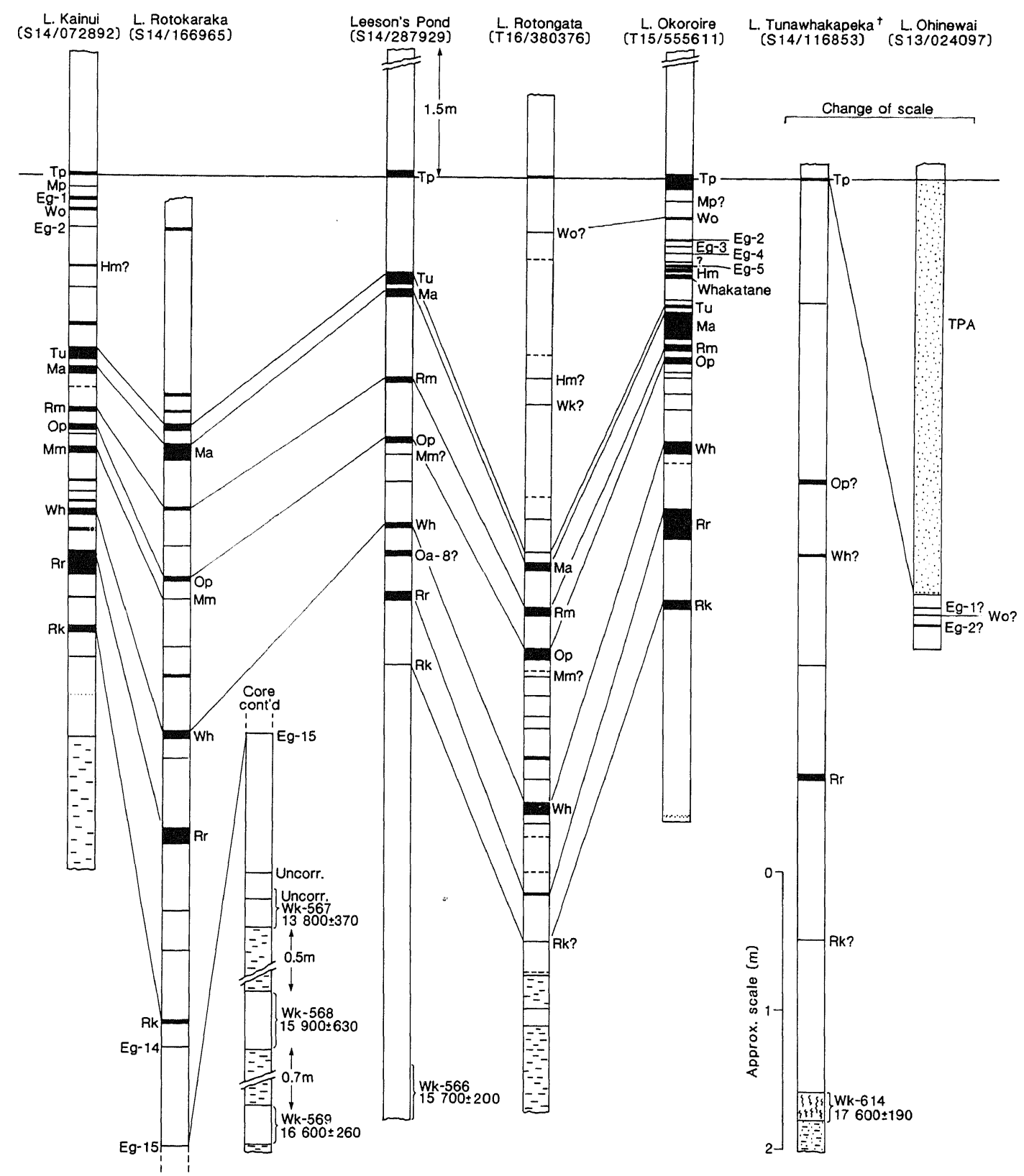

L. Rotomanuka, 14 cores; L. Maratoto, 33 (see Green \& Lowe 1985); L. Ngaroto, 2; L. Mangakaware, 3; L. Mangahia, 3; L. Rotoroa (= Hamilton Lake), 2; L. Rotokauri, 2; L. Kainui (=Lake D), 2; L. Rotokaraka, 4; Leeson's Pond, 3; L. Rotongata, 4; L. Okoroire, 3 (see Lowe 1986a); L. Tunawhakapeka † (drained "Rototuna Lake"), 1; L. Ohinewai, 2. *Approximate grid reference of coring site based on the national $1000 \mathrm{~m}$ grid of the 1:50 000 topographical map series (NZMS 260). †This lake was cored using a motorised Gidding's auger. 
laterally continuous and generally follow the lake basin topography. It is possible that some of the tephric material derives from co-ignimbrite ashfall (see section on tephra distribution and implications below).

Most of the tephra layers can be readily correlated from core to core and from lake to lake using their field properties and stratigraphy (e.g., Fig. 3). The sources and identifications of the tephras given in Fig. 2 and Table 1 are based on their mineralogical and chemical composition and their age, as described in later sections, together with their stratigraphic relationships.

\section{Tephra properties}

Generally, most of the tephras occurring within the lake sediment are compact, macroscopic layers ranging in thickness from c. $2 \mathrm{~mm}$ to c. $110 \mathrm{~mm}$. The layers are usually continuous (i.e., go right across the core), but occasionally they are partly dislocated or appear as ashy "pods" within the sediment. Upper contacts are commonly smooth in appearance but the overlying sediments usually contain indistinct ash grains disseminated over some millimetres; the lower contacts are often irregular and wavy but sharp (Fig. 3).

The thick tephras (i.e., > c. 5-10 mm) are typically pale coloured (white or grey, sometimes stained yellowish-orange) and stand out against the darker lake sediment (Fig. 3). They are usually glassy, pumiceous, and of rhyolitic origin. (An exception is the Mangamate Tephra which is greyish-black and andesitic.) Texturally, they range from fine ash (<c. $\left.{ }^{1} / 16 \mathrm{~mm}\right)$ to fine lapilli (c. $\left.2-4 \mathrm{~mm}\right)$, but commonly comprise medium (c. $1 / 1 \sigma^{1 / 2} \mathrm{~mm}$ ) or coarse (c. $1 / 2-2 \mathrm{~mm}$ ) ash. Normal or multiple graded bedding occurs frequently (e.g., Fig. 4A, B), especially in beds $\geq c$. $15 \mathrm{~mm}$ thick. Reverse grading is rare, however. Generally, these thicker tephras are the most distinctive and thus the most useful sediment markers in the cores. They include Taupo, Tuhua, Mamaku, Opepe, Mangamate, Waiohau, Rotorua, Rerewhakaaitu, and Okareka tephras (Fig. 2; Green \& Lowe 1985).

The thin tephra beds (i.e., <c. $5 \mathrm{~mm}$ ) are commonly darker coloured (dark grey, brown), often speckled and more crystal rich, rather indistinct, and of andesitic origin. The dark colour in some is due to staining by lake sediment. Some beds are greyish-white and yellowish-brown and can be either andesitic or rhyolitic in composition. Generally, these thinner beds consist of fine or medium-coarse ash and usually show little or no graded bedding, being well sorted.
Other tephras occur as diffuse, gritty zones in the lake sediments that may span up to c. $100 \mathrm{~mm}$, or as very thin (<c. 1-2 mm), virtually microscopic layers best seen by X-radiography (Fig. 5; Lowe et al. 1981).

\section{Bioturbation and stratigraphic reliability}

Many of the tephras have irregular or diffuse contacts, or are manifest as relatively thin, indistinct zones within the sediments. Ash-filled burrow (?) channels may extend well below the base of some; gas-pocket holes may also occur (Fig. 4B). Most of this dissemination and disruption is short range and is probably attributable to bioturbation. (Other processes such as wave action, particularly near the lake margins, may also be important, e.g., Green \& Lowe 1985.) The chief biological mixing agents are probably chironomids (tube formers) and other insect larvae, oligochaeie worms, and crustacea (e.g., cladocerans such as chidorids), which tend to predominate in the sediments in shallow water near lake shores (Boubée 1983; J. D. Green pers. comm. 1987). Chironomid larvae can burrow up through ash layers at least $6 \mathrm{~mm}$ thick (Edmondson 1984).

The effect of this bioturbation on the stratigraphic relationships of the tephras has, in general, been minor, and is usually visible and hence avoidable in sampling. The rates of sediment deposition, although relatively slow, have generally been sufficient to separate each successive tephra deposit with an intervening layer of scdiment. Where tephras occur very closely together in the cores (i.e., within a few millimetres of one another) they may show some intermixing (detected by mineralogical or electron microprobe analysis described below).

Most tephras in the cores occur as essentially unmixed and discrete units which systematically increase in age with increasing depth (see chronology section), and clearly represent, to a large degree, a faithful stratigraphic record of tephra deposition (cf. Sarna-Wojcicki et al. 1981; Anderson et al. 1984). It is possible that some of the tephric material in the lakes was washed or blown in from the catchment (e.g., see Thompson et al. 1986), or reworked by wave action or currents soon after the main fall event, but any material so reworked effectively has the same age as the original fallout tephra (Fisher \& Schmincke 1984).

Tephra duplication in the cores (e.g., Anderson et al. 1984) does not seem to have occurred-all but one of the tephra layers identified could be matched with known eruptions (or with known periods of 
Fig. 3 Three longitudinally sliced cores from Lake Rotomanuka showing prominent, compact, ashgrade tephra layers preserved within dark, fine-grained organic lake sediment. The slight upward curvature of some of the beds is a function of the piston-coring technique. The "Andesitic tephra" in these cores may comprise two units, from Tongariro (Oa-4) (predominant) and Egmont (Eg-12), which have the same ${ }^{14} \mathrm{C}$ age (see text).

(Photo: R.R. Julian)
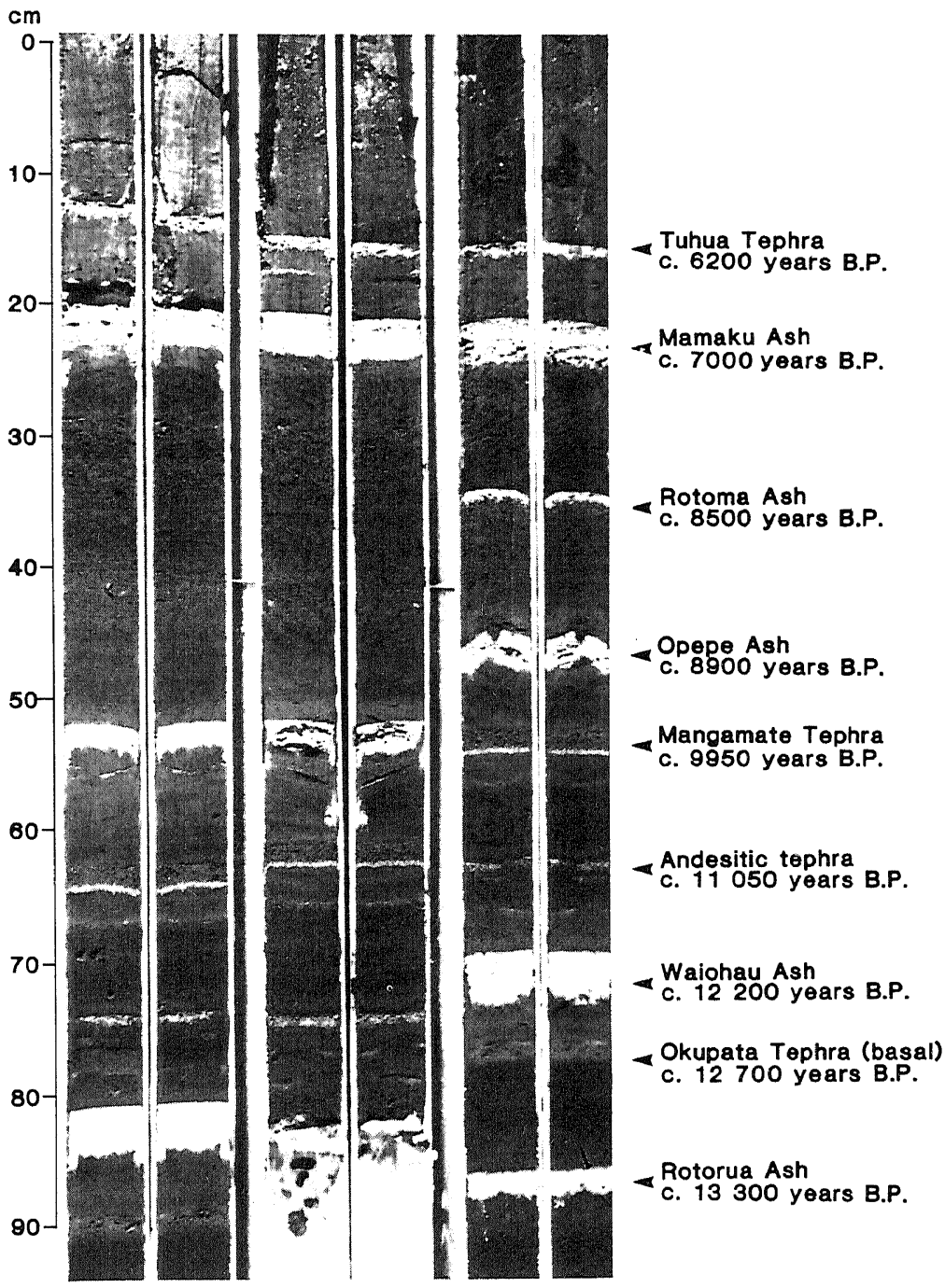

activity) from the North Island volcanoes. The "unknown" (rhyolitic) layer, found intermittently between Mamaku Ash and Rotoma Ash in a few cores (Fig. 2), probably resulted from reworking of one or both of these tephras, either naturally or by a smearing action brought about by the coring method in its initial period of use (Lowe 1987).

\section{Number of eruptives and total thickness of deposits}

Forty one tephras have so far been identified in the lakes. A few of the tephras are microscopic units and were detected by electron microprobe analysis of sparse glass shards or titanomagnetite grains. Notall of the tephras occur in any one core, nor in one single

lake. The longest and most detailed record of all the lakes cored is found in Lake Rotomanuka (Fig. 2), which, together with the centrally located Lake Maratoto, has been the focus of most laboratory analysis.

The total thickness of the visible lacustrine tephras in the Ohaupo-Hamilton area is, on average, c. $25 \mathrm{~cm}$ (Table 2). In the northern Waikato (e.g., Lakes Rotokaraka, Leeson's Pond) the average thickness is estimated at c. $15-20 \mathrm{~cm}$, and in the east (e.g., Lake Okoroire), c. $40-45 \mathrm{~cm}$. These thicknesses are approximate because the irregular boundaries and diffuse nature of some of the tephras can make measurements imprecise. Also, the thickness of individual tephras may differ in cores from the same lake. 


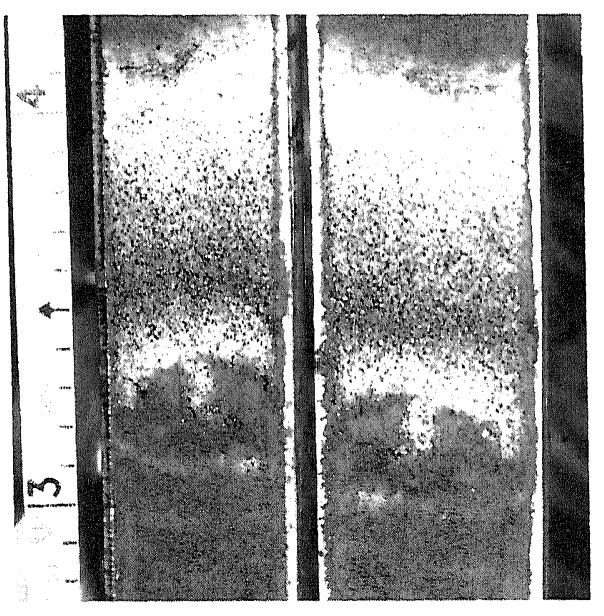

Fig. 4A Normally graded Rotorua Ash Formation, Lake Okoroire, comprising mainly pumiceous coarse ash overlain by fine ash (latter contains very sparse fine lapilli). Scale marks are $1 \mathrm{~cm}$ apart.

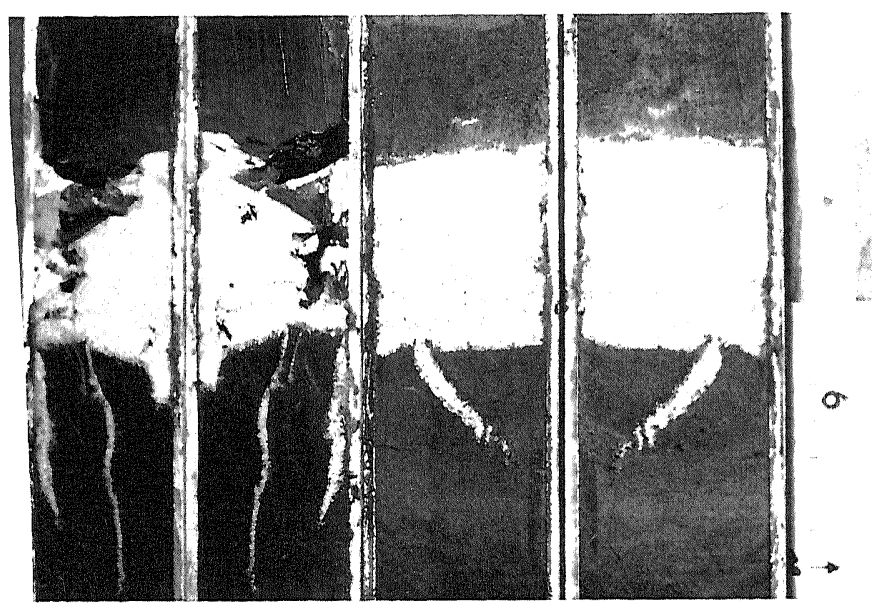

Fig. 4B Rotorua Ash Formation in two cores from Lake Kainui, showing multiple bedding (from base up have medium ash, fine ash, pumiceous coarse ash, medium ash, fine ash), gas-pocket holes (core on left), and coarse ash-filled burrow(?) channels underneath the tephra. Scale marks are $1 \mathrm{~cm}$ apart.

\section{Relationship to thickness of subaerial deposits}

The very firm, compact nature of most of the thicker lacustrine tephras contrasts with the friability and low bulk densities (c. $0.7-0.9 \mathrm{~g} / \mathrm{cm}^{3}$ ) commonly associated with their subaerial equivalents (e.g., Gradwell 1982). The lacustrine tephras are coherent and probably have bulk densities of c. $1.5 \mathrm{~g} / \mathrm{cm}^{3}$, based on their field properties and measurements made on tephras in similar settings by Borchardt et al. (1973) and Anderson et al. (1984). Rai (in Borchardt et al. 1973) estimated from bulk density comparisons that onland tephras are about 1.75 times as thick as equivalent bog or lacustrine tephras. Similarly, Watkins et al. (1978) and Sparks et al. (1983) converted submarine tephra thicknesses to equivalent dry-land (original) thicknesses by correcting for the effects of compaction and bioturbation. Thus, the expected equivalent dryland tephra thicknesses in ihe Waikato area may be roughly estimated, in part, by using a compaction correction factor of 1.75 (Table 2). An additional correction for dissemination can be made using the results of X-radiography. In a short core from Lake Mangakaware, the total thickness of visible tephras is $43 \mathrm{~mm}$; the X-radiograph or "true" thickness is 53 mm (see Lowe et al. 1981). Thus, visual measurements of tephra thickness may underestimate the true thickness by c. $20 \%$. Because only a few cores were $\mathrm{X}$-rayed, it is not known if this value applies generally, but it seems reasonable to conservatively adopt $10 \%$ as a correction for dissemination. Therefore $10 \%$ of the original visible thickness measurements may be added to the compactioncorrected thickness to obtain a total equivalent dryland thickness (Table 2). These recalculated figures are generally consistent with thickness measurements of subaerial tephra profiles at various sites in the Waikato region (e.g., Pullar 1967; Pullar \& Birrell 1973b; Lowe 1986b).

\section{CHRONOLOGY OF THE TEPHRAS}

\section{Sampling}

Lake sediment enclosing the tephras was sampled for radiocarbon dating to determine the tephras' age of deposition and thus time of eruption. Stratigraphic columns showing the sampling positions with respect to the tephras identified are given in Fig. 6.

The slices of sediment, generally $1-2 \mathrm{~cm}$ thick, were extracted from above and below the tephra layers using stainless steel cutters. Although the slices were deliberately kept as thin as possible, they nevertheless represent an accumulation time of perhaps c. 100-200 years because of the slow rates of sedimentation in the Waikato lakes. Consequently, the dates obtained may be limited in their accuracy, with respect to the age of deposition of the tephras, by up to several hundred years. However, this potential reduction in accuracy is 


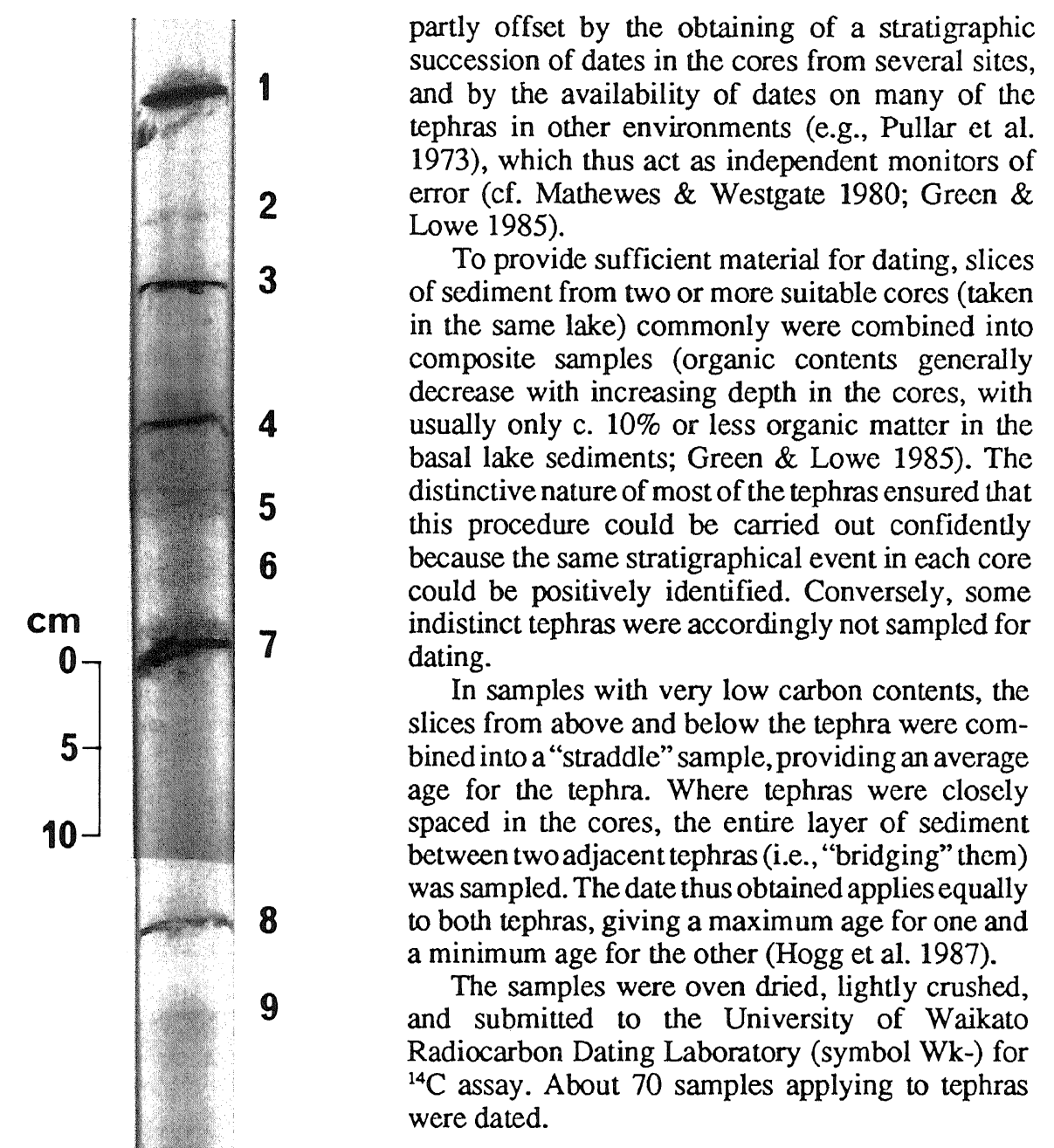

Results and interpretation

The dates and associated error terms (one standard deviation) obtained from cores from five lakes are given in Fig. 6. Ages adopted in this study for the tephras are summarised in Table 1 . Where a few specific tephra layers were not dated, their ages of deposition were interpolated using sedimentation rates. Ages so obtained are reasonably reliable because they are well constrained by the dates on material in adjacent parts of the core.

The ages accord with the stratigraphy (increase down the cores) with few age inversions from tephra to tephra. Commonly, the dates above and below a tephra are statistically indistinguishable (using the method of Currie 1981). Some of the dates on the mainly inorganic basal lake sediments (e.g., Wk$240,-504)$ have large errors that reflect heavy dilution in the dating procedure because of a low 

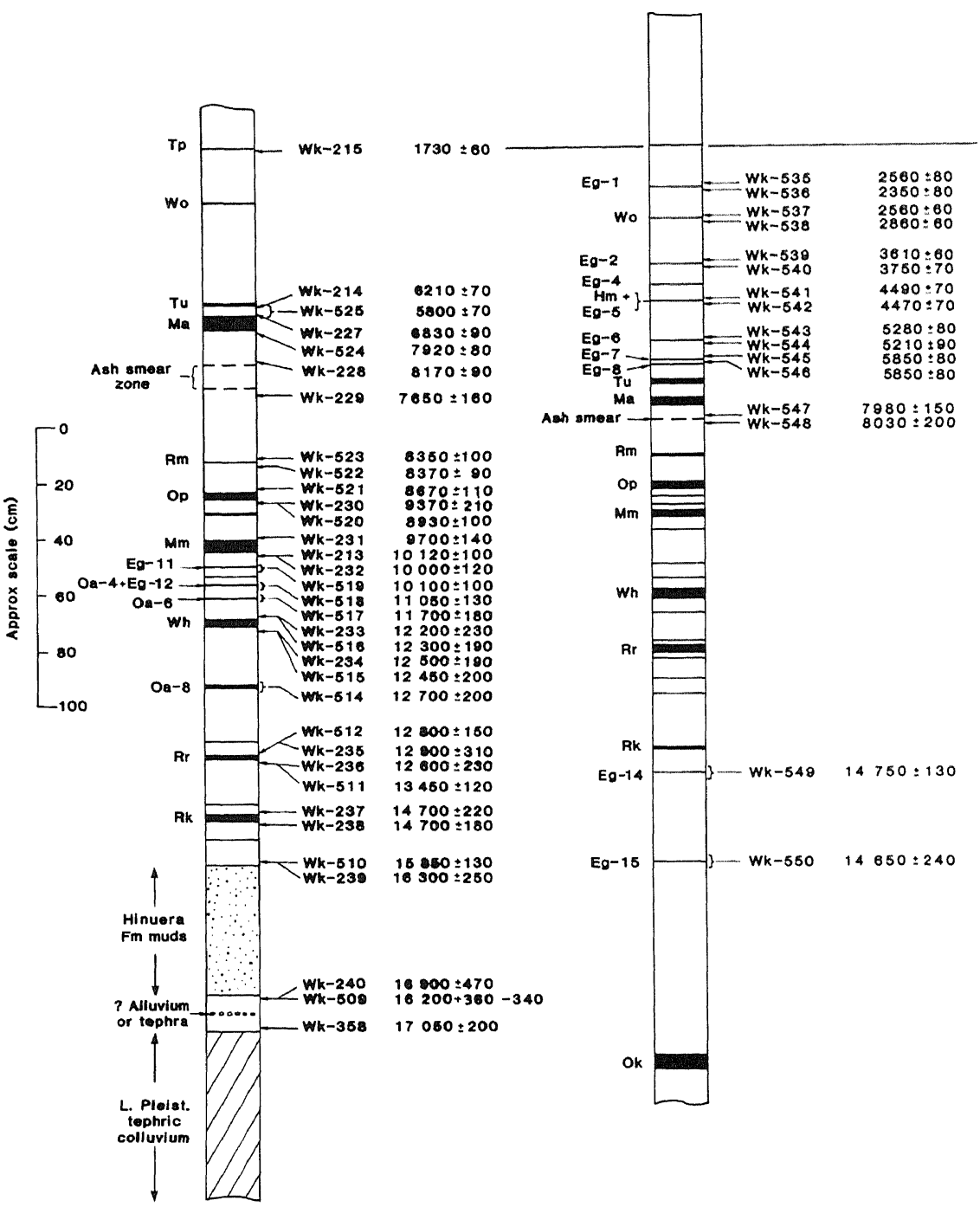

Table 2 Total thickness of tephras* younger than and including Rerewhakaaitu Ash in the Waikato area based on lake core measurements, and estimated equivalent dry-land thicknesses. Values in millimetres.

\begin{tabular}{lcccc}
\hline & $\begin{array}{c}\text { Total visible } \\
\text { thickness in } \\
\text { cores } \\
\text { (average) }\end{array}$ & $\begin{array}{c}\text { Compaction - } \\
\text { corrected } \\
\text { thickness } \\
\text { (visible x 1.75) }\end{array}$ & $\begin{array}{c}\text { Estimated } \\
\text { dissemination } \\
\text { thickness } \\
\text { (visible x0.1) }\end{array}$ & $\begin{array}{c}\text { Total equivalent } \\
\text { dry-land } \\
\text { thickness } \\
\text { (approx.) }\end{array}$ \\
\hline Hamilton-Ohaupo & 25 & 44 & 2.5 & 47 \\
Whitikahu-Morninsville & 20 & 35 & 2.0 & 37 \\
Okoroire-Tirau & 42 & 74 & 4.2 & 78 \\
\hline
\end{tabular}

*Assumed to represent airfall material only, with no modification to thickness by postdepositional reworking or catchment erosion. 


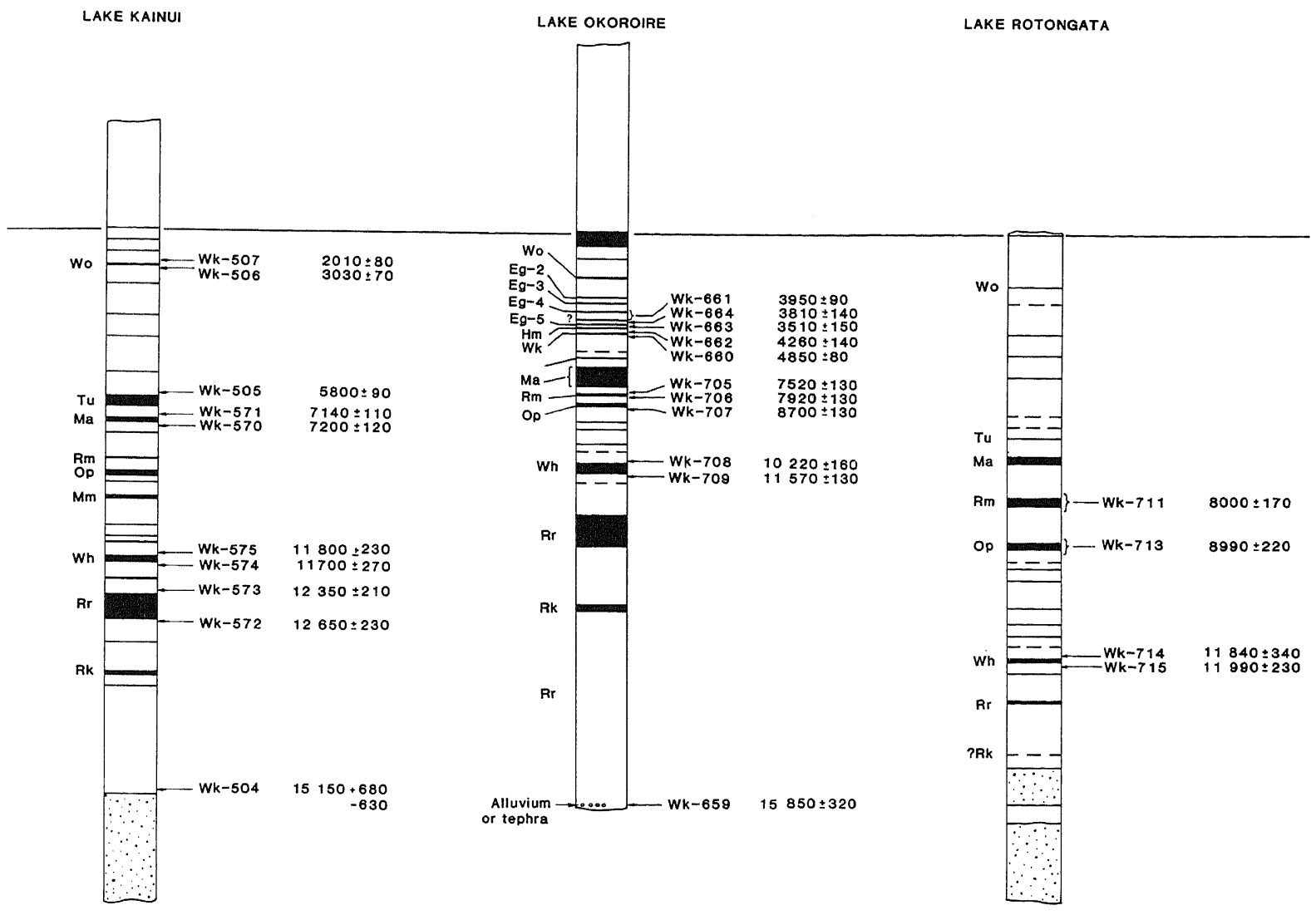

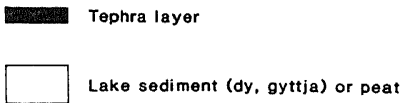

Fig. 6 (opposite and above) Stratigraphic columns showing sampling positions and ${ }^{14} \mathrm{C}$ dates obtained on tephras in cores from five Waikato lakes (Fig. 1). For discussion see text and Hogg et al. (1987). Symbols for named tephras are explained in Table 1 and Fig. 2. carbon content and a small sample size (Hogg et al. 1987).

To a large extent the dates agree closely with those obtained for the same tephras elsewhere (e.g., Pullar \& Heine 1971; Vucetich \& Pullar 1973; Cole \& Nairn 1975; Froggatt 1981a; Hogg \& McCraw 1983), although relatively few dates are available for andesitic eruptives from Tongariro and Egmont (e.g., Topping 1973; Neall \& Alloway 1986).

Anomalous ages are associated with the eruptions of the Okataina-derived Rotoma Ash (c. 8500 years B.P.?) and Waiohau Ash (c. 12200 years B.P.?). Generally, the dates obtained on the lake cores for Rotoma Ash are younger, and for Waiohau Ash, older, than those obtained at other sites (e.g., Pullar \& Heine 1971; Nairn 1981); the differences in age amount to c. 500-1000 years or so. This discrepancy is discussed more fully in Green \& Lowe (1985), Lowe \& Hogg (1986), and Hogg et al. (1987). Some of the dates on Rotorua Ash are significantly younger than the normally accepted age of c. 13450 years (Nairn 1980), although errors are quite large.

Okareka Ash, positively identified only in cores from Lake Rotomanuka (Fig. 2), was not dated directly in this study because enclosing sediment 
contained insufficient carbon for normal ${ }^{14} \mathrm{C}$ laboratory requirements. An age of c. 17000-18000 years is suggested from approximate sedimentation rates. This age range is supported by consideration of the dates obtained for Lake Maratoto sediments, the oldest of which are $17050 \pm 200$ years B.P. (Wk358; Green \& Lowe 1985). Because Okareka Ash is apparently absent from the Lake Maratoto sediments, then it is likely to be older than c. 17000 years.

Elsewhere, Okareka Ash has not been dated, but Nairn (1981) estimated its age as c. 17000 years based on its stratigraphic relationship to dated overlying (Rerewhakaaitu) and underlying (Te Rere, Kawakawa) tephras (Vucetich \& Pullar 1969). An arbitrary age of c. 17000 years is therefore adopted here (Table 1), but an older age may yet eventuate for this tephra.

\section{TEPHRA COMPOSITION AND IDENTIFICATION}

In hand specimen and under the binocular microscope the pale coloured rhyolitic tephras are predominantly vitric with both platy and sparsely porphyritic pumiceous shards. They also contain subordinate feldspar and mafic crystals or crystal fragments, commonly with glass selvedges. Lithic fragments are rare. The andesitic tephras, usually darker in colour, are composed mainly of feldspar and mafic crystals, often with narrow glassy selvedges, and of greyish, moderately vesicular, "andesitic scoria" comprising microlites or crystallites of feldspar and other constituents in a glassy matrix (see section on light minerals below). Glass shards are relatively uncommon and usually vesicular (e.g., see Kirkman \& McHardy 1980), and may have a "dirty" appearance due to slight surficial weathering. Sparse lithics of varying composition may also occur.

\section{Sampling and laboratory analysis}

All the tephra layers in cores from Lakes Rotomanuka, Maratoto, and Kainui, and some of the tephras in Lakes Okoroire, Rotongata, and Mangahia, were sampled (a total of about 150 samples). The 63-250 $\mu \mathrm{m}(2-4 \phi)$ size fractions of the samples of each of the tephras were split into heavy mineral (sp. gr. $>2.9 \mathrm{~g} / \mathrm{cm}^{3}$ ) and light mineral (sp. gr. $<2.9 \mathrm{~g} / \mathrm{cm}^{3}$ ) components using standard heavy liquid and Frantz electromagnetic methods (Lowe 1981a; Froggatt \& Gosson 1982), and their proportions were determined gravimetrically. These components were further separated and prepared as necessary for analysis by petrographical microscope (point count of detrital mounts), X-ray diffraction (XRD) (powder mounts), scanning electron microscope (SEM) (unpolished and polished mounts), and electron microprobe (EMP) (polished blocks of various constituents) (Lowe 1981a; Froggatt \& Gosson 1982; Hume \& Nelson 1982; Froggatt 1983).

\section{Correlations with source volcanoes and named eruptives}

The analytical results, when considered together and with reference to previous work, permit the correlation of each of the distal tephras to one of six volcanic centres (Fig. 1; Lowe in press). The main diagnostic criteria are summarised in Table 3. By taking into account the tephras' stratigraphic position and age, correlations with named proximal eruptives from each of these source volcanoes have been established (stratigraphic names are summarised in Table 1).

Several modifications to the provisional tephrostratigraphy recorded in Lowe et al. (1980) are made. "Waimihia Lapilli" is re-identified here as Whakaipo Tephra (see glass chemistry section below). "?Rotoma Ash" and "Unnamed ash" were re-identified as Mamaku Ash and Rotoma Ash, respectively, by Green \& Lowe (1985). "? Okato Tephra" is re-identified here as the lowest unit of the Okupata Tephra Formation (Oa-8), taken to be equivalent to the "basal lapilli" bed described by Topping (1973). Dates on Okupata Tephra near source are (NZ1374) $9790 \pm 160$ years B.P. (min.) and (NZ1189) $12450 \pm 340$ years B.P. (max.) (Topping 1973, p. 410). In addition, the formation is overlain by Karapiti Tephra and underlain by an unnamed andesitic tephra and Rotorua Ash (Topping \& Kohn 1973; Froggatt \& Solloway 1986), and hence its age is further constrained by the ages of these tephras. From these ages and the descriptions in Topping (1973) it appears that Okupata Tephra Formation is time transgressive, with units erupted at various intervals between c. 10000 and c. 12 500-13000 years ago. (A. member of Okupata Tephra Formation is dated at c. 10300 years B.P. in Lowe \& Hogg 1986.) Consequently, andesitic tephras with Tongariro source characteristics that occur between Mangamate Tephra (?Te Rato Lapilli) and Rotorua Ash in the lake cores might best be considered as representatives of the Okupata Tephra Formation. 


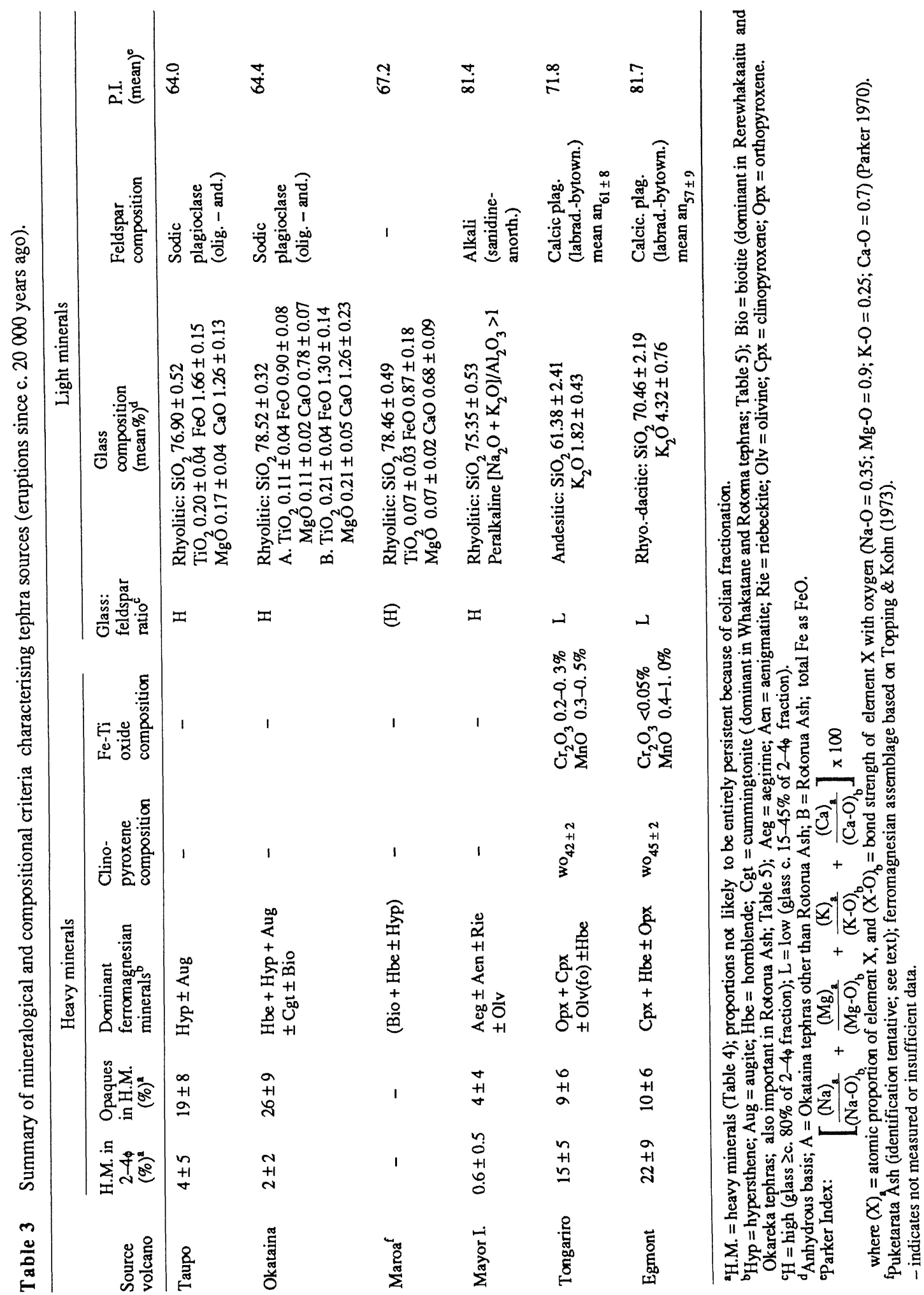


Oa-8 is assumed to be a correlative of the basal lapilli unit of Topping (1973), and has a date of (Wk-514) $12700 \pm 200$ years B.P. (Fig. 6). A thin andesitic tephra is found stratigraphically between this tephra (Oa-8) and the underlying Rotorua Ash (Rr) in some lake cores (Fig. 2) and, based on its proximity to the latter tephra, has an estimated age of c. 13100 years. This tephra is regarded here as an "unnamed tephra" (cf. Topping 1973).

Informal designations are used where correlations are currently uncertain (e.g., for the Egmont eruptives, Eg-1 to Eg-15), and where no formal name has previously been defined (e.g., unnamed members of the Okupata Tephra Formation, Oa-1 to Oa-8). The analytical data from the heavy and light mineral fractions providing the basis for these correlations are presented and discussed below.

\section{Heavy minerals}

The $2-4 \phi$ heavy mineral fractions consist chiefly of ferromagnesian silicates and ubiquitous $\mathrm{Fe}-\mathrm{Ti}$ oxides (opaque minerals). Results from the gravimetric and modal analyses are summarised in Tables 4 and 5. Some samples contained insufficient heavy minerals for analysis.

\section{Proportions of heavy and opaque minerals}

Although the figures in Table 4 show considerable variation, some general trends are evident. The tephras from the rhyolitic Taupo and Okataina

Table 4 Abundances of heavy minerals and opaque minerals in 2-4 $\phi$ fractions of tephras in Waikato lake cores. Values are mean \pm 1 standard deviation; $\mathrm{n}=$ number of samples of tephras analysed for each volcanic centre.

\begin{tabular}{lcrrr}
\hline $\begin{array}{l}\text { Volcanic } \\
\text { centre }\end{array}$ & $\begin{array}{c}\text { Heavy } \\
\text { minerals } \\
(\mathrm{wt. \% )}\end{array}$ & $\mathrm{n}$ & $\begin{array}{c}\text { Opaque } \\
\text { minerals } \\
(\text { vol.\%) } \dagger\end{array}$ & $\mathrm{n}$ \\
\hline Taupo & $3.6 \pm 4.6$ & 10 & $18.9 \pm 7.8$ & 24 \\
Okataina & $1.7 \pm 1.5$ & 26 & $26.1 \pm 9.4$ & 38 \\
Maroa & trace & 1 & 0 & 1 \\
Mayor Island & $0.6 \pm 0.5$ & 4 & $4.3 \pm 4.2$ & 5 \\
Tongariro & $15.2 \pm 5.4$ & 15 & $9.1 \pm 5.5$ & 21 \\
Egmont & $22.1 \pm 9.3$ & 11 & $10.2 \pm 6.1$ & 25 \\
\hline
\end{tabular}

*Proportion of heavy minerals in 2-4申 fractions. Values for samples containing sparse heavy minerals are liable to have low precision.

tProportion, by point count, of opaque minerals in the 2-46 heavy mineral fraction (see Table 5).

Samples from Lakes Rotomanuka, Maratoto, Kainui, and Okoroire.
Volcanic Centres are relatively low in heavy minerals $(<5 \%)$ but high in Fe-Ti oxides (c. 20-30\%), especially Okataina. The opposite applies to the andesitic Tongariro and Egmont derived tephras, which are high in heavy minerals (c. $15-25 \%)$ and relatively low in oxides (10\%). Samples of the pantelleritic Mayor Island derived tephras are very low in both heavy minerals (1\%) and oxides (5\%). (The unnamed c. 14500 year old Mayor Island tephra consists solely of glass, as does the Maroa derived Puketarata Ash.)

These trends in relative abundances are broadly similar to those of near-source eruptives, taking into consideration differences in methodology, size fractions examined, and type of sample: the andesitic tephras are relatively mafic rich and $\mathrm{Fe}-\mathrm{Ti}$ oxide poor; the rhyolitic tephras are mafic poor but with variable, sometimes high, Fe-Ti oxide abundances (cf. Clark 1960; Ewart 1963; Gow 1968; Cole 1970, 1978; Kohn \& Neall 1973; Bucket al. 1981; Neall et al. 1986). Some of the variations are likely to be due in part to the effects of eolian fractionation (e.g., see Fisher \& Schmincke 1984; Juvigné \& Porter 1985), as is evident particularly for the tephras consisting wholly of glass.

\section{Ferromagnesian mineral assemblages}

The ferromagnesian silicate minerals gencrally have properties similar to those described in Lowe (1981a). Most of the minerals are euhedral with glassy rims, and typically contain abundant inclusions such as apatite, glass, and opaque minerals.

The ferromagnesian assemblages (Table 5) can be classed into five main groups, each of which characterises one of the source volcanoes, as follows:

Group 1 (Taupo): Hypersthene \pm augite. Group 2 (Okataina): Hornblende + hypersthene + augite \pm cummingtonite \pm biotite. Group 3 (Tongariro): Orthopyroxene + clinopyroxene \pm olivine \pm hornblende. Group 4 (Egmont): Clinopyroxene + homblende \pm orthopyroxenc. Group 5 (Mayor Island): Aegirine \pm aenigmatite \pm ricbeckite \pm olivine \pm ferro-hedenbergite \pm tuhualite.

(The only recent eruptive from the Maroa Volcanic Centre, Puketarata Ash, contains mainly biotite and hormblende \pm hypersthene near source; Topping \& Kohn 1973.) Apatite and zircon may also occur in small amounts $(<5 \%)$, with zircon being a noticeable constituent in the Okataina derived tephras in particular. The proportions of minerals within most groups may vary from sample to 
Table 5 Dominant ferromagnesian minerals in tephras in cores from Waikato lakes and bogs.

\begin{tabular}{|c|c|c|c|c|c|c|c|c|c|c|c|c|}
\hline & \multicolumn{5}{|c|}{ Taupo derived tephras } & \multicolumn{7}{|c|}{ Okataina derived tephras } \\
\hline & $\mathrm{Tp}$ & $\mathrm{Mp}$ & Wo & $\mathrm{Hm}$ & Op & Wk & $\mathrm{Ma}$ & $\mathbf{R m}$ & Wh & $\mathrm{Rr}$ & Rk & Ok \\
\hline Hyp & $81-91$ & 91 & $70-92$ & 92 & $62-72$ & $8-21$ & $25-75$ & $4-57$ & $34-73$ & $19-59^{a}$ & $2-13$ & $23-43$ \\
\hline Aug & $2-17$ & 7 & $6-23$ & 3 & $24-33$ & $1-13$ & $3-28$ & $3-37$ & $2-36$ & $4-38$ & $1-34$ & $4-22$ \\
\hline $\mathrm{Hbe}$ & $2-6$ & 2 & $1-7$ & 3 & $2-5$ & $5-12$ & $17-47$ & 4-14 & $5-38$ & $30-34$ & $18-21$ & $16-32$ \\
\hline $\mathrm{Cgt}$ & $0-1 ?$ & - & - & 2 & $0-\mathrm{tr}$ & $56-84$ & $0-1$ ? & $10-86$ & $0-t$ & $0-t r$ & - & $1-5$ \\
\hline Bio & - & - & $0-1$ & - & - & $0-\mathrm{tr}$ & - & $0-6$ & $0-3$ & $3-12$ & $32-79$ & $15-40$ \\
\hline OPA & $20-35$ & 14 & $16-23$ & 23 & $11-30$ & $16-20$ & $19-45$ & $8-25$ & $16-42$ & $6-29$ & $4-13$ & $22-31$ \\
\hline $\mathrm{n}$ & 3 & 1 & 3 & 1 & 4 & 3 & 7 & 6 & 6 & 3 & 2 & 3 \\
\hline
\end{tabular}

\begin{tabular}{lccccccccccc} 
& \multicolumn{10}{c}{ Tongariro derived tephras } \\
\cline { 2 - 10 } & $\mathrm{Mm}$ & $\mathrm{Oa}-1$ & $\mathrm{Oa}-2$ & $\mathrm{Oa}-3$ & Oa-4 & Oa-5 & Oa-6 & Oa-7 & Oa-8 & un & Rt \\
\hline Opx & $43-44$ & $35-49$ & 30 & $56-68$ & $63-65$ & 72 & $50-82$ & 61 & $56-67$ & $69-70$ & $37-49$ \\
Cpx & $22-30$ & $34-47$ & 57 & $29-34$ & $32-34$ & 25 & $17-44$ & 36 & $31-42$ & $27-30$ & $39-59$ \\
Hbe & $0-1$ & $11-16$ & 9 & tr- 1 & tr-2 & 3 & $1-4$ & 2 & $0-1$ & tr-1 & $3-8$ \\
Olv & $26-34$ & $1-4$ & 4 & $3-9$ & $2-3$ & tr & $0-10$ & 1 & $1-4$ & $1-2$ & $0-8$ \\
OPA & $6-13$ & $7-32$ & 23 & $8-20$ & $9-15$ & 9 & $7-12$ & 7 & $2-8$ & $3-6$ & $4-14$ \\
n & 3 & 3 & 1 & 2 & 3 & 1 & 3 & 1 & 4 & 2 & 3
\end{tabular}

Egmont derived tephras

\begin{tabular}{lccccccccccccc} 
& Eg-1 & Eg-2 & Eg-3 & Eg-4 & Eg-5 & Eg-6 & Eg-7 & Eg-8 & Eg-9 & Eg-10 & Eg-13 & Eg-14 & Eg-15 \\
\hline Opx & $0-2$ & $0-2$ & 6 & $0-2$ & $0-16$ & $2-35$ & tr-4 & 7 & $0-8$ & 9 & $4-13$ & $2-23$ & $1-7$ \\
Cpx & $49-57$ & $42-55$ & 49 & $46-75$ & $43-72$ & $47-64$ & $79-89$ & 54 & $57-60$ & 54 & $75-76$ & $53-86$ & $83-93$ \\
Hbe & $43-49$ & $45-58$ & 43 & $25-52$ & $28-47$ & $17-34$ & $11-17$ & 39 & $32-43$ & 37 & $12-21$ & $12-21$ & $6-12$ \\
Olv & tr? & - & - & - & - & - & - & - & - & - & - & $0-3 ?$ & - \\
Ctg & - & - & $2 ?$ & - & $0-4$ & tr- 17 & - & - & - & - & - & - & - \\
OPA & $1-5$ & $1-11$ & 6 & $4-9$ & $2-15$ & $3-4$ & $9-11$ & 18 & $7-23$ & 12 & $6-8$ & $3-22$ & $12-14$ \\
n & 2 & 3 & 1 & 2 & 3 & 2 & 2 & 1 & 2 & 1 & 2 & 3 & 3
\end{tabular}

Tuhua Tephra (Mayor Island)

\begin{tabular}{|c|c|c|c|c|c|}
\hline & 1 & 2 & 3 & 4 & 5 \\
\hline Aeg & 40 & 87 & 86 & 28 & 98 \\
\hline Aen & 1 & $1 ?$ & 3 & 2 & - \\
\hline Rie & 4 & 1 & 3 & 1 & - \\
\hline Tuh & - & - & $t r$ & - & - \\
\hline Olv & 3 & 2 & 3 & 1 & - \\
\hline Opx $x^{c}$ & 6 & $t r$ & 2 & 26 & 1 \\
\hline $\mathrm{Cpx}^{\mathrm{d}}$ & 29 & 7 & 3 & 26 & 1 \\
\hline Hbe & 17 & 2 & - & 16 & - \\
\hline OPA & 2 & 7 & 1 & $?$ & 1 \\
\hline
\end{tabular}

$\mathrm{Hyp}=$ hypersthene; $\mathrm{Aug}=$ augite Hbe = calcic hornblende; $\mathrm{Cgt}=$ cummingtonite; $\mathrm{Bio}=$ biotite; Opx = orthopyroxene; $\mathrm{Cpx}=$ clinopyroxene; $\mathrm{Aeg}=$ aegirine; $\mathrm{Aen}=$ aenigmatite; $\mathrm{Rie}=$ riebeckite Tuh $=$ tuhualite. Values $=\%$ range of ferromagnesian silicate minerals (summed to $100 \%) ; t=t$ trace $(<1 \%) ; ?=$ uncertain; $-=$ not detected. OPA $=\%$ opaque minerals in $2-4 \phi$ heavy mineral fraction (by point count). $n=$ number of samples analysed (individual analyses for specified lakes or bogs are given in Lowe 1987). Tephra abbreviations are given in Table 1.

ancludes ferrohypersthene.

${ }^{b}$ Cgt suggests Whakatane Ash (Wk) may be present.

'Mainly hypersthene; anal. 1 includes ferrohedenbergite.

${ }^{\mathrm{d}}$ Excludes aegirine; mainly augite.

Samples from Mayor I.: 1, L. Rotomanuka; 2, L. Kainui; 3, L. Maratoto; 4, L. Mangahia; 5, L. Okoroire. 
sample; for example, in group 4, clinopyroxene may normally predominate over hornblende in some Egmont tephras but in others homblende is dominant.

Some of the ferromagnesian minerals are useful as marker minerals for particular tephras or volcanic centres (Lowe etal. 1980): aegirine is diagnostic of Tuhua Tephra (Mayor Island); cummingtonite occurs as the dominant ferromagnesian mineral in Whakatane Ash and Rotoma Ash (Haroharo Complex, Okataina); biotite is dominant in Rerewhakaaitu Ash and Okareka Ash (Tarawera Complex, Okataina) (it may also amount to c. $10 \%$ in Rotorua Ash), and characteristically occurs in Puketarata Ash (Topping \& Kohn 1973); olivine (forsteritic, $\mathrm{fo}_{84-87}$ ) is found in most of the Tongariro eruptives (e.g., Mangamate Tephra), but usually in only small amounts. (Olivine may also occur in rare quantities in Mayor Island and Egmont eruptives, but is of fayalitic composition: Buck et al. 1981; Weaver in Houghton \& Wilson 1986; Wallace et al. 1986.) That the distinctive peralkaline mineral assemblage associated with Tuhua Tephra contains a proportion of calcalkaline minerals in some samples (Table 5) indicates contamination of these after deposition (probably by the succeeding Egmont derived tephras, Eg-7, Eg-8?).

The mineralogical results agree closely with previous findings on pyroclastics and lavas associated with the Taupo, Okataina, and Mayor Island volcanoes (e.g., Ewart 1963, 1971; Cole 1970; Topping \& Kohn 1973; Kohn \& Glasby 1978; Howorth et al. 1980; Buck et al. 1981; Froggatt 1981a; Hogg \& McCraw 1983; Lowe \& Hogg 1986). The results are also consistent with mineralogical analyses of Tongariro and Egmont eruptives, although most published results relate to work done on near-source lavas (e.g., Clark 1960; Gow 1968; Kohn \& Neall 1973; Cole 1978; Franks 1984; Cole et al. 1986; Neall \& Alloway 1986; Neall et al. 1986).

\section{Ferromagnesian mineral composition}

Chemical analyses representative of most of the ferromagnesian mineral phases were obtained by EMP. A range of selected analyses is given in Lowe (1987). The analyses were undertaken (1) to confirm the optical mineralogy, and (2) to examine their potential use as an adjunct means of fingerprinting tephras (e.g., see Smith \& Leeman 1982; Federman \& Scheidegger 1984). Seventy-seven pyroxene grains, commonly zoned, in tephras from the Tongariro and Egmont centres, were specifically analysed by EMP to see if these centres could be effectively separated.

The analyses, all done on grain cores, provisionally suggest some degree of separation. The Tongariro clinopyroxenes, usually colourless, project mainly as augite (mean $\mathrm{wo}_{41.8 \pm 1.5} ; 14$ analyses) in the wo-en-fs diagram. The Egmont clinopyroxenes, usually green-lemongreen to bluish green, generally contain more $\mathrm{Ca}$ and project as salite or high-Ca augite ( $\mathrm{wO}_{44.6}+2.3 ; 38$ analyses) (Lowe in press; cf. Cole et al. 1986; Wallace et al. 1986). The Tongariro orthopyroxenes (21 analyses) usually project as hypersthene (total range $\mathrm{en}_{3369}$ ), but the few available Egmont orthopyroxene analyses (4) show variable composition $\left(\mathrm{en}_{46}{ }_{75}\right)$.

Egmont hornblendes were additionally examined by EMP (32 analyses), chicfly to characterise and classify the types present. Most are optically green-brown "calcic homblendes" and, based on Leake's (1978) nomenclature and assuming all $\mathrm{FcO}$ (total iron) is in the $\mathrm{Fe}^{2+}$ form, include ferroan pargasite, pargasite, and ferroan pargasitic homblende varicties (Lowe 1987). A second, subordinate, group of dark reddish-brown amphiboles probably comprise "oxyhornblendes" (Deer et al. 1963), and are classed as magnesiohastingsite or magnesio-hastingsitic hornblende (assuming an $\mathrm{Fe}^{3+}: \mathrm{Fe}^{2+}$ ratio of about $4: 1$, hence $\mathrm{Fe}^{3+}>\mathrm{Al}^{\mathrm{Vi}}$; Leake 1978).

\section{Fe-Ti oxides}

The Fe-Ti oxides comprise mostly titanomagnetite with rare magnetite and ilmenite, based on EMP studies. Very few grains showed exsolution features (Fig. 7A), although inclusions are relatively common (Fig. 7B). Selected analyses for some Tongariro and Egmont tephras are listed in Table 6.

Fe-Ti oxide compositions, determined in various ways, have proved useful in tephra correlation studies in New Zealand and elsewhere (e.g., Kohn 1970; Topping \& Kohn 1973; Westgate \& Gorton 1981; King et al. 1982; Hogg \& McCraw 1983). Kohn \& Neall (1973) demonstrated that Tongariro tephras could be distinguished from those of Egmont by titanomagnetite chemistry as measured by emission spectrographic analysis. The Tongariro titanomagnetites contain more $\mathrm{Cr}$ (especially), $\mathrm{V}$, and $\mathrm{Ni}$, but less $\mathrm{Mn}$, than titanomagnetites from Egmont eruptives (sce also Kohn 1973).

These findings are used here to attempt to distinguish Tongariro and Egmont derived tephras-the respective sources being indicated by 

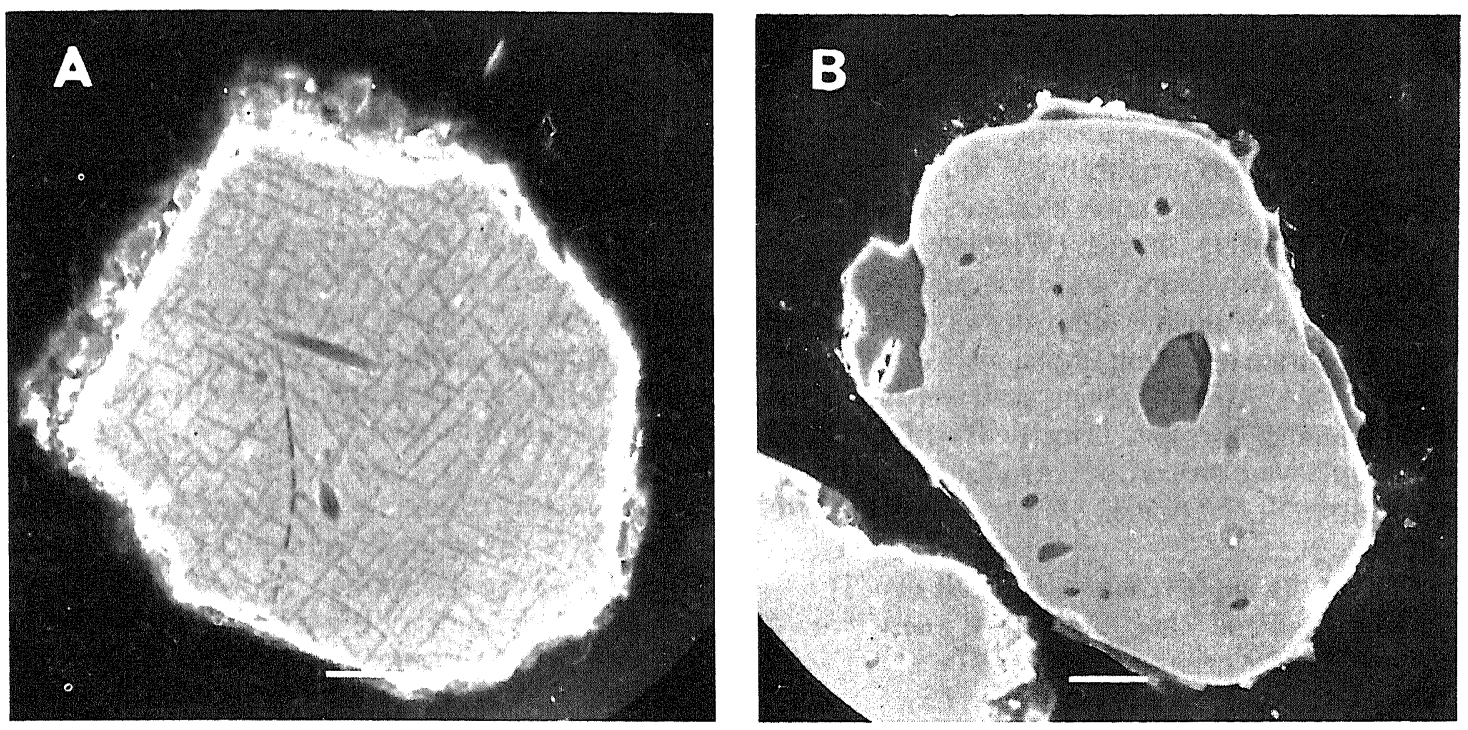

Fig. 7 A Three sets of exsolution lamellae in polished Ti-magnetite grain. (Mangamate Tephra, L. Rotomanuka.) Scale bar $=15.5 \mu \mathrm{m}$. B Inclusions in polished Ti-magnetite grain with a narrow glassy rim. (Mangamate Tephra, $\mathrm{L}$. Rotomanuka.) Scale bar $=24 \mu \mathrm{m}$.

Table 6 Electron microprobe analyses of titanomagnetities in some Egmont and Tongariro tephras. Analyses recalculated using the method of Carmichael (1967).

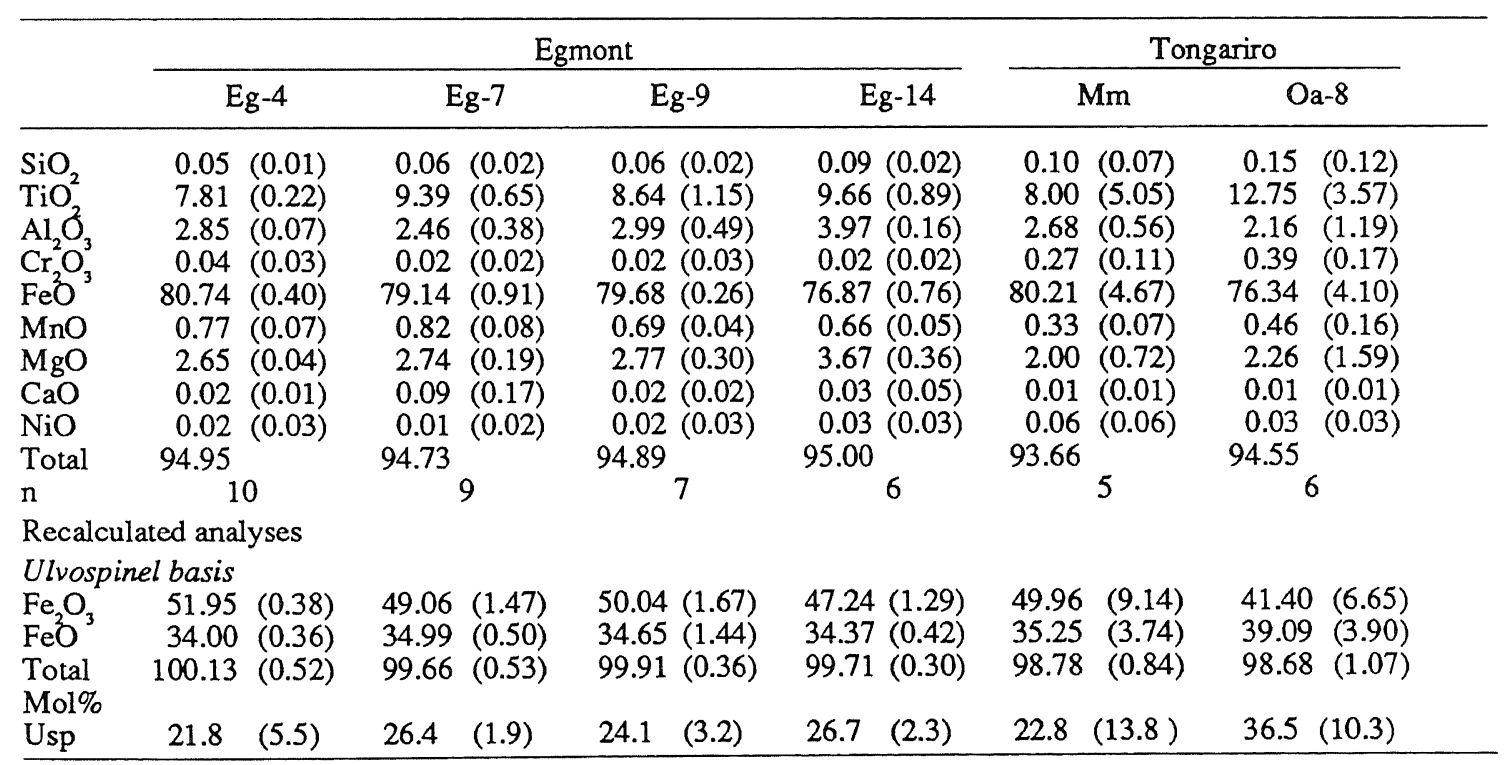

Analyses obtained using a $12 \mathrm{nA}$ beam current at $15 \mathrm{kV}$ and a $3 \mu \mathrm{m}$ beam. $\mathrm{n}=$ number of analyses in mean with 1 standard deviation in parentheses. Oa-8 samples from L. Maratoto; rest from L. Rotomanuka. See Table 1 for tephra abbreviations. 
the ferromagnesian mineralogy - by EMP analysis of their titanomagnetites. No attempt was made to distinguish between the individual eruptives pertaining to one or to the other of these centres. The EMP has limited capabilities for measuring elements other than major elements and certain transition or heavy metals (Westgate \& Gorton 1981). Thus vanadium was not analysed, and measurements of nickel, almost always below the probe's accurate detection limits, were accordingly of little value. About 200 analyses were obtained from 18 tephra samples. Usually 10-15 grains in each sample were probed, but in samples containing very sparse $\mathrm{Fe}-\mathrm{Ti}$ oxides, fewer analyses were obtainable.

The results support Kohn \& Neall (1973) and generally indicate that Tongariro and Egmont eruptives may be separated using $\mathrm{Cr}\left(\right.$ as $\left.\mathrm{Cr}_{2} \mathrm{O}_{3}\right)$ and $\mathrm{Mn}(\mathrm{MnO})$ abundances in particular. $\mathrm{Cr}_{2} \mathrm{O}_{3}$ always occurs in measurable quantities (c. $0.2-0.3 \%$ ) in the Tongariro derived samples, but is invariably very low (usually present in trace quantitites but normally below accurate detection limits) in Egmont derived samples (<c. 0.05\%). $\mathrm{MnO}$ concentrations in the Egmont samples (range c. $0.4-1.0 \%$ ) usually exceed those of the Tongariro samples (c. $0.3-$ $0.5 \%$ ), but there is some overlap (Fig. 8; Table 6). Chemical analyses of titanomagnetites in Taranaki tephras by Franks $(1984$, p. 98) show broadly corroborative values: $\mathrm{MnO}$ concentrations average $0.8 \%$ (range $0.5-1.2 \%$ )and $\mathrm{Cr}_{2} \mathrm{O}_{3}$ concentrations average $0.028 \%(280 \mathrm{ppm}$ )(range $<0.01-0.06 \%)$. The results should be treated with caution because the differences in element concentration are small in absolute terms, and the samples show a range of values for $\mathrm{MnO}$ in particular. More work is required to determine if other elements may be used to discriminate between tephra sources, or between individual tephras.

Because the EMP is a grain-discrete method, mixed populations in samples may be readily detected (e.g., Kohn 1979; Westgate \& Gorton 1981; Hogg \& McCraw 1983). Assuming that the above differences in $\mathrm{Cr}_{2} \mathrm{O}_{3}$ and $\mathrm{MnO}$ concentrates in the titanomagnetites are reliable indicators of a Tongariro or Egmont source, the analyses showed that some samples may contain admixed Tongariro and Egmont derived grains. This was evident mainly in tephras deposited in the period c. $10000-12000$ years ago. For example, in Fig. 8, triangles mark analyses of individual grains from a "single" tephra layer in Lake Rotomanuka that possibly contains two admixed tephras, Oa-4 and Eg-12. Ferro- magnesian mineralogical data indicates that $\mathrm{Oa}-4$ is dominant, however (Lowe 1987). Analyses from several other samples suggest that Egmont eruptives may have "dusted" the Waikato lakes between c. 13500 and 14500 years ago, around the same time that various tephras from other sources were being deposited (Table 1). The mixing so indicated probably arises because such concentrations of eruptions over relatively short time intervals mean that the deposits are very closely spaced in the lake sediments-hence they are potentially subject to bioturbation and other short-range mixing processes.

Analyses of suitable Fe-Ti oxide pairs enable pre-eruptive temperature estimates, and oxygen fugacities, to be determined by geothermometry (Buddington \& Lindsley 1964; Spencer \& Lindsley 1981). Besides their petrological and volcanological value, these parameters may be a useful aid in correlating tephras (e.g., Smith \& Leeman 1982; Froggatt \& Solloway 1986). Results from a limited number of Tongariro and Egmont Fe-Ti oxide pairs are given in Table 7. The Ti-magnetite/ilmenite sample pairs are assumed to have co-existed in equilibrium in the magma. Support for this equilibrium is shown by the semiparallelism of tie lines (Storey 1985) in a triangular plot of the samples' minor elements $\mathrm{Mn}, \mathrm{Mg}$, and $\mathrm{Al}+\mathrm{Cr}$ (Lowe 1987).

Estimated oxide equilibrium temperatures for two pairs from the same tephra sample (Oa-4) show agreement. Other Tongariro and Egmont eruptives show a range of temperatures and oxygen fugacities (Table 7).

\section{Light minerals}

Based on XRD analysis and examination by petrological microscope, the light minerals of the $2-4 \phi$ fractions of tephras from the rhyolitic volcanoes comprise mainly glass (usually $>$ c. 80 wt.\%) plus small amounts of plagioclase feldspar, quartz, and rare alkali feldspar.

Tephras from the andesitic volcanoes are dominated by plagioclase feldspar (usually c. 55-85\%). Plagioclase is usually the most abundant phenocryst in Tongariro and Egmont lavas (Cole et al. 1986; Neall et al. 1986). Glassy (isotropic) material makes up c. $15-45 \%$ of the tephras' light mineral fractions and is commonly vesicular and softish and fragile looking; many grains contain semi-oriented lathlike feldspar microlites. The Tongariro tephras generally contain the least glass. Many plagioclase grains have narrow glassy 


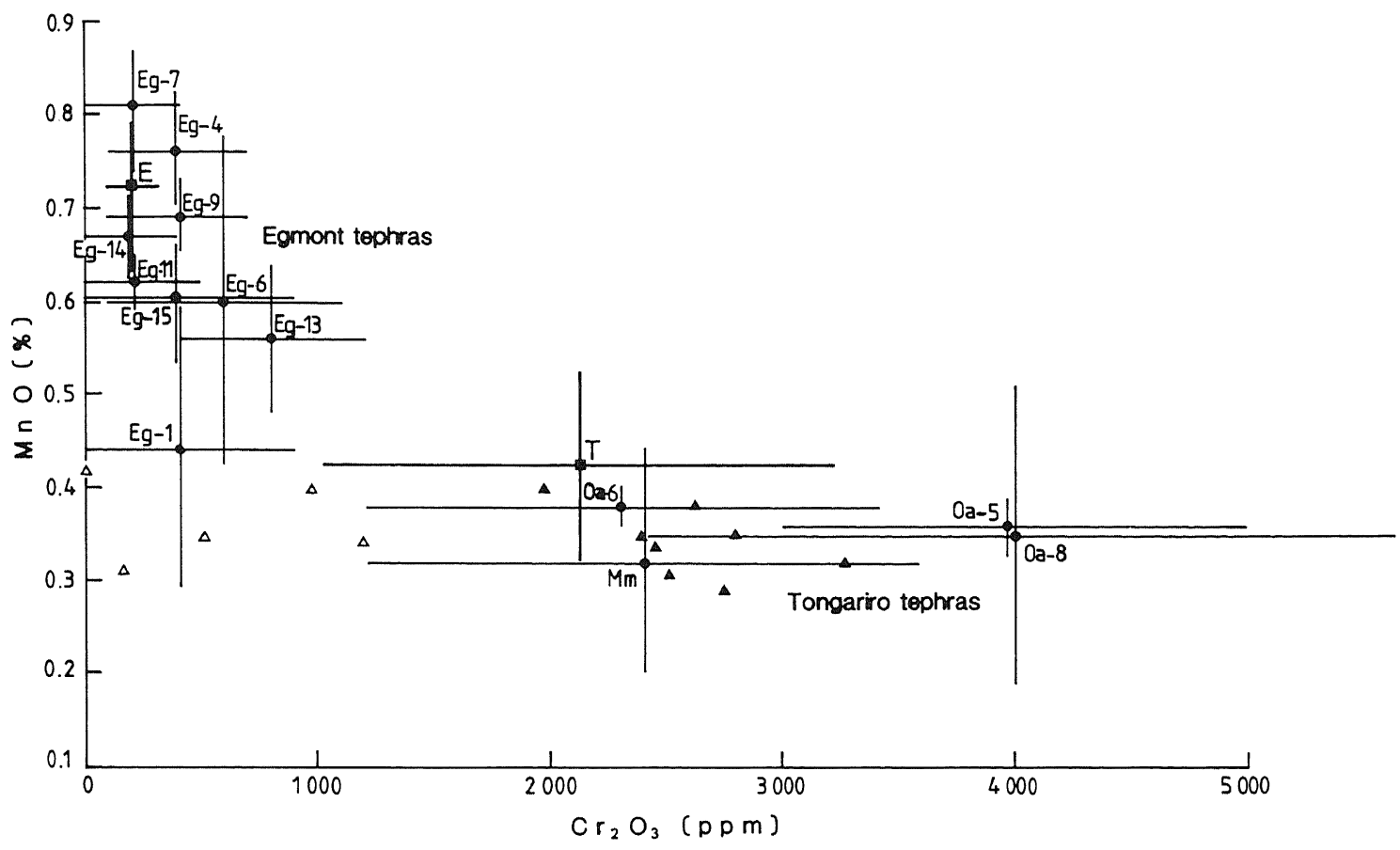

Fig. $8 \mathrm{MnO}$ versus $\mathrm{Cr}_{3} \mathrm{O}_{3}$ plot for Ti-magnetites of some Egmont and Tong ariro derived tephras in Lake Rotomanuka (determined by EMP). Bars represent one standard deviation from the mean. Numbers of grains analysed in Egmont tephras: Eg-1, 11; Eg-4, 10; Eg-7, 8; Eg-9, 7; Eg-11, 10; Eg-13, 12; Eg-14, 10; Eg-15, 10. Tongariro tephras: Mm, 8; Oa-5, 4; Oa-6, 3; Oa-8, 12 (abbreviations are explained in Table 1). $\mathrm{E}=$ mean \pm 1 s.d. of Kohn \& Neall's (1973) analyses (as oxides) of Egmont derived tephras younger than c. 16000 years $(n=23) ; T=$ mean \pm 1 s.d. of Kohn's $(1973)$ analyses (as oxides) of Tongariro derived tephras younger than c. 15000 years $(n=20)$. The $\mathrm{Cr}_{2} \mathrm{O}_{3}$ analyses of the Egmont tephras are approximate (see text). Triangles mark analyses of a single tephra layer in Lake Rotomanuka that possibly comprises two admixed tephras: $\mathrm{Oa}-4$ (closed), Eg-12 (open).

mantles. SEM photomicrographs illustrating some of these features are given in Fig. 9A-H.

Generally, the tephric material looks fresh and unaltered, but occasionally the SEM showed evidence of incipient weathering in the form of micropits and tiny fragments ("adhering dust") on grain surfaces (e.g., Fig. 9H; cf. Heiken \& Wohletz 1985). Some labradorite or bytownite grains in an Egmont derived sample had unusual tubular, "boxcanyon" grooves about $1.5-2 \mu \mathrm{m}$ in width. These were interpreted as biogenic by Lowe (1987). Vesicle fillings (including diatom frustules) may also occur, particularly in the andesitic scoriaceous/ pumiceous pyroclasts.

Elongated, parallel vesicles characterise many shards in samples of Tuhua Tephra.

\section{Feldspar composition}

Feldspar composition was investigated by EMP. About 130 analyses were obtained, around $90 \%$ of these being on samples of the plagioclase-rich
Tongariro and Egmont derived tephras. Mainly grain cores were probed. Six representative analyses are listed in Table 8; a fuller range is available in Lowe (1987).

The Tongariro and Egmont derived tephras show a range of plagioclase compositions, with both groups containing andesine, labradorite, and bytownite (Fig. 10). The Tongariro samples (68 analyses) range from $\mathrm{an}_{35-85}$ with the mean of all analyses being an ${ }_{61 \pm 8}$; Egmont samples (49 analyses) are similar, having a range of $\mathrm{an}_{33-81}$ and a mean of $a n_{57 \pm 9}$ (Lowe 1987). These results are in close agreement with the findings of Cole et al. (1986) and Neall et al. (1986) for Tongariro and Egmont lavas, respectively.

The few analyses obtained on the tephras derived from rhyolitic sources indicate that the feldspars are generally much less calcic. The Taupo and Okataina derived tephras usually contain oligoclase and andesine ( $\mathrm{an}_{23-38}$; Lowe 1986b, p .297) (cf. 
Table 7 Electron microprobe analyses of co-existing titanomagnetite-ilmenite pairs, recalculated after Carmichael (1967). Oxide equilibrium temperatures and oxygen fugacities deduced from curves of Spencer \& Lindsley (1981) as modified by Anderson \& Lindsley (1985), using a computer programme written by J. C. Stormer.

\begin{tabular}{|c|c|c|c|c|c|c|c|}
\hline \multirow[b]{2}{*}{ Sample } & \multicolumn{2}{|c|}{ Egmont tephras } & \multicolumn{5}{|c|}{ Tongariro tephras } \\
\hline & $\mathrm{Eg}-2$ & $\mathrm{Eg}-13$ & $\mathrm{Mm}$ & $\mathrm{Oa}-4$ & $\mathrm{Oa}-4$ & $\mathrm{Oa}-5$ & $\mathrm{Oa}-8$ \\
\hline $\begin{array}{l}\text { Spinel phase } \\
\mathrm{SiO} \\
\mathrm{TiO}_{2} \\
\mathrm{Al}_{2} \mathrm{O}_{3} \\
\mathrm{Cr}_{2} \mathrm{O}_{3} \\
\mathrm{Fe}_{3} \mathrm{O}_{3} \\
\mathrm{FeO}_{3} \\
\mathrm{MnO} \\
\mathrm{MgO} \\
\mathrm{CaO} \\
\mathrm{NiO} \\
\mathrm{Total} \\
\text { Mol\% } \\
\text { Usp }\end{array}$ & $\begin{array}{r}0.04 \\
7.97 \\
2.14 \\
0.04 \\
52.43 \\
34.68 \\
1.11 \\
2.06 \\
0.02 \\
0.04 \\
100.53 \\
\\
22.3\end{array}$ & $\begin{array}{r}0.08 \\
11.09 \\
4.00 \\
0.00 \\
44.49 \\
35.88 \\
0.63 \\
3.62 \\
0.00 \\
0.00 \\
99.78 \\
\\
30.6\end{array}$ & $\begin{array}{r}0.09 \\
4.89 \\
2.28 \\
0.30 \\
55.39 \\
33.16 \\
0.28 \\
1.25 \\
0.02 \\
0.00 \\
97.66 \\
\\
14.5\end{array}$ & $\begin{array}{r}0.08 \\
13.13 \\
2.35 \\
0.24 \\
40.89 \\
39.90 \\
0.34 \\
2.05 \\
0.03 \\
0.05 \\
99.06\end{array}$ & $\begin{array}{r}0.16 \\
13.23 \\
2.35 \\
0.26 \\
40.98 \\
40.30 \\
0.38 \\
2.08 \\
0.00 \\
0.00 \\
99.75\end{array}$ & $\begin{array}{r}0.05 \\
13.72 \\
2.77 \\
0.37 \\
40.31 \\
39.78 \\
0.40 \\
2.66 \\
0.02 \\
0.10 \\
100.16\end{array}$ & $\begin{array}{r}0.09 \\
18.01 \\
1.16 \\
0.28 \\
32.71 \\
43.66 \\
0.50 \\
2.29 \\
0.01 \\
0.01 \\
98.71\end{array}$ \\
\hline $\begin{array}{l}\text { Rhombohed } \\
\mathrm{SiO}_{2} \\
\mathrm{TiO}_{2} \\
\mathrm{Al}_{2} \mathrm{O}_{3} \\
\mathrm{Cr}_{2} \mathrm{O}_{3} \\
\mathrm{Fe}_{2} \mathrm{O}_{3} \\
\mathrm{FeO} \\
\mathrm{MnO} \\
\mathrm{MgO} \\
\mathrm{CaO} \\
\mathrm{NiO} \\
\mathrm{Total} \\
\mathrm{Mol} \mathrm{R}_{2} \mathrm{O}_{3}\end{array}$ & $\begin{array}{c}\text { Iral phas } \\
0.02 \\
30.52 \\
0.48 \\
0.08 \\
42.21 \\
24.07 \\
0.51 \\
1.46 \\
0.13 \\
0.11 \\
99.58\end{array}$ & $\begin{array}{r}0.04 \\
35.74 \\
0.46 \\
0.26 \\
32.00 \\
30.51 \\
0.18 \\
0.84 \\
0.00 \\
0.00 \\
100.04\end{array}$ & $\begin{array}{r}0.08 \\
21.24 \\
1.49 \\
0.23 \\
59.77 \\
14.54 \\
0.57 \\
2.29 \\
0.00 \\
0.00 \\
100.20\end{array}$ & $\begin{array}{r}0.01 \\
44.41 \\
0.41 \\
0.08 \\
19.24 \\
30.31 \\
0.34 \\
5.17 \\
0.04 \\
0.04 \\
100.03\end{array}$ & $\begin{array}{r}0.04 \\
44.62 \\
0.36 \\
0.13 \\
17.55 \\
33.78 \\
0.28 \\
3.42 \\
0.00 \\
0.01 \\
100.19\end{array}$ & $\begin{array}{r}0.05 \\
33.81 \\
0.54 \\
0.03 \\
36.90 \\
25.55 \\
0.21 \\
2.60 \\
0.00 \\
0.07 \\
99.76\end{array}$ & $\begin{array}{r}0.02 \\
37.71 \\
0.60 \\
0.14 \\
29.13 \\
26.59 \\
0.17 \\
4.00 \\
0.01 \\
0.03 \\
98.40\end{array}$ \\
\hline $\begin{array}{l}\text { Temp. }\left({ }^{\circ} \mathrm{C}\right) \\
\log \mathrm{fO}_{2}\end{array}$ & $\begin{array}{r}934 \\
-9.27 \\
\end{array}$ & $\begin{array}{r}948 \\
-9.62 \\
\end{array}$ & $\begin{array}{r}974 \\
-8.06 \\
\end{array}$ & $\begin{array}{c}917 \\
-10.80\end{array}$ & $\begin{array}{c}908 \\
-11.04 \\
\end{array}$ & $\begin{array}{r}1020 \\
-8.84\end{array}$ & $\begin{array}{r}1095 \\
-8.68\end{array}$ \\
\hline
\end{tabular}

Oa-8 sample from L. Maratoto; rest from L. Rotomanuka. See Table 1 for tephra abbreviations.

Ewart 1969; Cole \& Nairn 1975). The peralkaline Mayor Island derived Tuhua Tephra contains alkali feldspar, both sanidine (or ${ }_{53-73}$ ) and anorthoclase (or ${ }_{35}$ ) (cf. Ewart et al. 1968b; Buck et al. 1981; Hogg \& McCraw 1983; Houghton \& Wilson 1986).

\section{Major element analysis of glass}

The suitability of the EMP for analysing glass for the characterisation and correlation of tephras has been well documented since the early work by Smith \& Westgate (1969) and others (e.g., see Federman \& Carey 1980; Froggatt 1983; Sarna-Wojcicki et al. 1984; Davis 1985; Reasoner \& Healy 1986). For several reasons, the method was seen to be potentially very useful for studying the tephras in this project. Firstly, the tephras in the Waikato region derive from multiple sources, and thus were likely to show a range of chemically distinct units. Where glass major element compositions proved too similar to distinguish one tephra from another, the continuous cores would enable them to be distinguished stratigraphically. Secondly, glass is the main constituent in the rhyolitic tephras and is easily separated. Thirdly, the EMP provides the only means of detecting and potentially correlating any distal deposits present as sparse glass shards only.

Accordingly, glass was analysed by EMP for nine elements using methods and conditions described by Froggatt \& Gosson (1982) and Froggatt (1983). These included using an $8 \mathrm{nA}$ beam at $15 \mathrm{kV}$, usually defocussed to $10 \mu \mathrm{m}$ but occasionally to $20 \mu \mathrm{m}$, to minimise loss of $\mathrm{Na}$ and $\mathrm{K}$. These last two elements were always analysed first 
Table 8 Some representative electron microprobe analyses* of plagioclase feldspars in andesitic tephras from Waikato lakes.

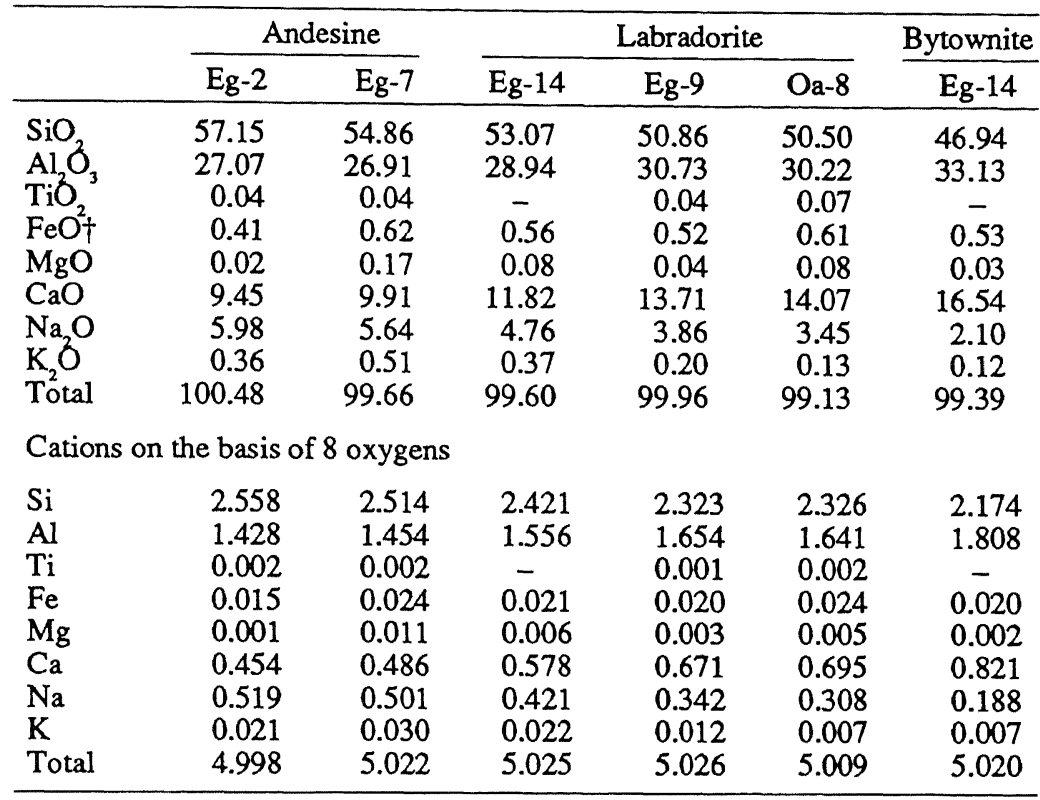

*Analyses on grain cores made using a $12 \mathrm{nA}$ beam at $15 \mathrm{kV}$ defocussed to $10 \mu \mathrm{m}$. Or-1A (orthoclase) standard was used regularly to check probe calibration. - = not detected.

$\dagger$ Total $\mathrm{Fe}$ as $\mathrm{FeO}$.

Sample Eg-14 from L. Rotomanuka; rest from L. Maratoto. Tephra abbreviations given in Table 1.

and second, respectively. Peak searches were carried out regularly, and glass and elemental standards were frequently analysed to check and correct for machine drift. (Glass standards used were: $\mathrm{KN}-18$, comenditic glass; VG-99, basaltic glass; VG-568, Yellowstone rhyolitic glass.) Froggatt (1982a, 1983) has demonstrated that the EMP technique has good reproducibility. Duplicate analyses on three glass shards from Mapara Tephra are given in Table 9.

Around 350 individual analyses were made, some 300 of these being on glass from the rhyolitic tephras. Only about 50 reliable analyses were obtained on glass in tephras from the andesitic sources-the sparseness of suitable glass in these samples, its high vesicularity and sometimes quasifragmented nature (e.g., Fig. 9E, F), plus the presence of microlites, made it difficult to probe. Occasionally, glass rims on plagioclase grains were probed. Usually a minimum of 10-12 analyses (each on an individual shard) were obtained for each of the rhyolitic tephras present. However, for the reasons noted above, the andesitic eruptives are less well represented, and only one or two analyses per sample were sometimes obtainable.

Representative analyses are listed in Table 10. The results are consistent with previous work on eruptives from the source volcanoes, although relatively few analyses on glass (as distinct from whole rock) have been published (cf. Ewart 1963; Ewart et al. 1968a, b; Cole \& Nairn 1975; Neall 1977; Kohn 1979; Froggatt 1983; Froggatt \& Solloway 1986; Houghton \& Wilson 1986). Taking into account the inherent variability normally associated with the EMP analysis of $\mathrm{Na}_{2} \mathrm{O}, \mathrm{K}_{2} \mathrm{O}$, and $\mathrm{SiO}_{2}$ in particular (Smith \& Westgate 1969), the glass populations of most of the rhyolitic tephras are relatively homogenous, as indicated by the generally low standard deviations (Table 10), hence unmixed. Thin tephras deposited just before or just after the thicker rhyolitic deposits may contain a "background" scatter of identifiable glass shards derived from the rhyolitic tephras, probably the result of bioturbation. 

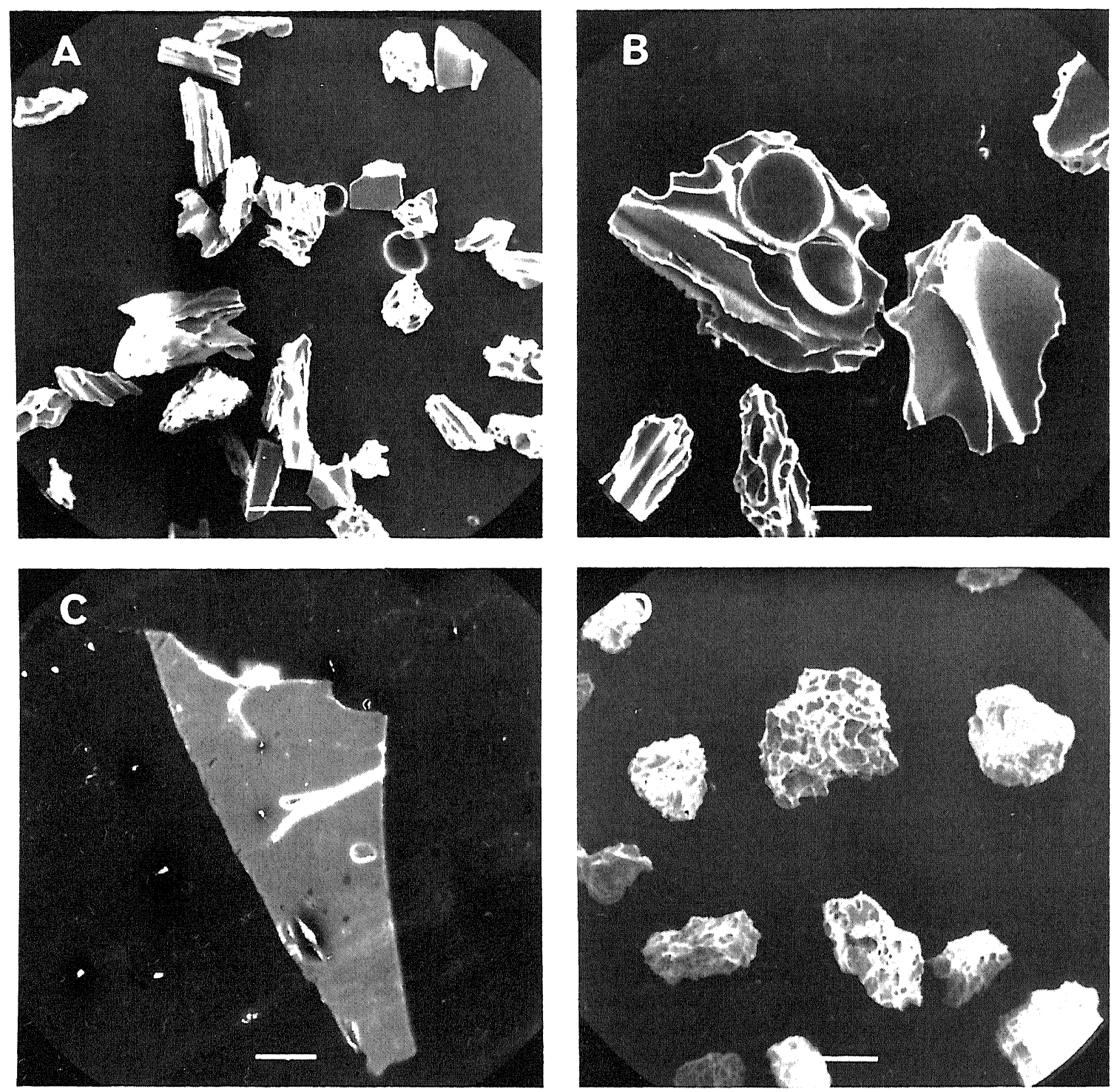

Fig. 9 A Pumiceous, platy, and cuspate rhyolitic glass shards with varying degrees of vesicularity (cf. Nelson et al. 1985); some show elongated, parallel vesicles. (Taupo Pumice, L. Rotomanuka.) Scale bar $=150 \mu \mathrm{m}$. B Cuspate and vesicular rhyolitic pumice shards (Taupo Pumice, L. Rotomanuka.) Scale bar $=60 \mu \mathrm{m}$. C Platy, rhyolitic shard (polished) of peralkaline composition. (Unnamed Mayor Island derived tephra, L. Rotomanuka.) Scale bar $=50 \mu \mathrm{m}$. D Blocky, andesitic pumiceous/scoriaceous glass shards. (Okupata Tephra, Oa-8, L. Maratoto.) Scale bar $=134 \mu \mathrm{m}$.

The Tongariro glasses (mean of all analyses $\mathrm{SiO}_{2}$ $=61 \pm 2 \%$ ) can be classed as andesitic (Lowe 1987). The Egmont glasses are noticeably more silicic (mean of all analyses $\mathrm{SiO}_{2}=70 \pm 2 \%$ ), hence are rhyolitic-dacitic, but otherwise chemically resemble andesitic glass; they have generally high $\mathrm{K}_{2} \mathrm{O}$ contents (mean of all analyses $4.32 \pm 0.76 \%$ ).
Parker's Index (P.I.) values (Parker 1970) for mean glass analyses from the tephras derived from each volcanic centre are as follows: Taupo, 64.0; Okataina, 64.4; Maroa, 67.2; Mayor Island, 81.4; Tongariro, 71.8; Egmont, 81.7 (higher values generally indicate greater susceptibility to weathering). The Mayor Island glasses have a mean peralkaline index of $1.33 \pm 0.1$ (Table 10). 

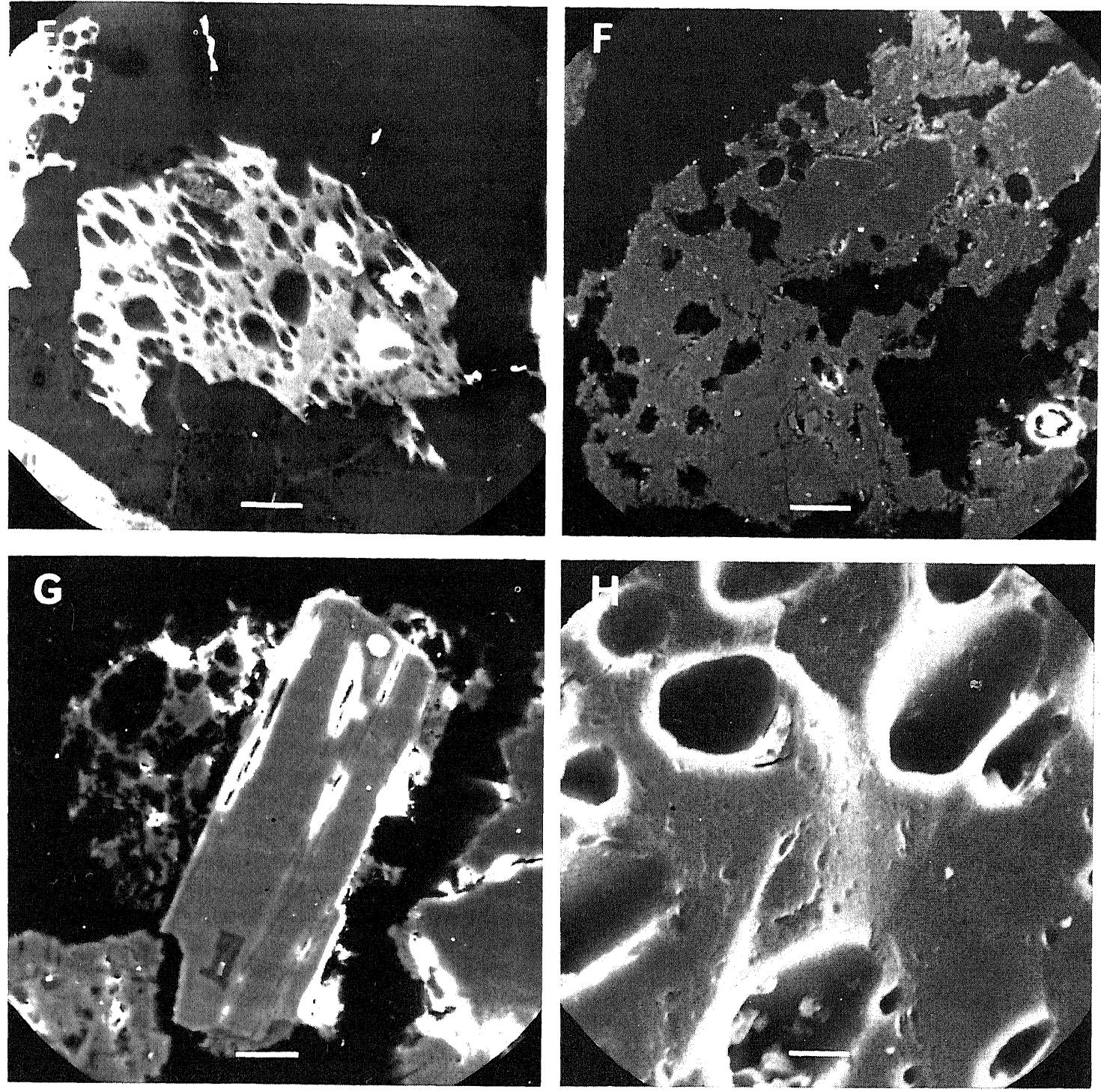

Fig. 9 E Highly vesicular andesitic pumiceous glass shard (polished) illustrating limited potential for probing with 10-20 $\mu \mathrm{m}$ beam. (Rotoaira Lapilli, L. Rotomanuka.) Scale bar $=33 \mu \mathrm{m}$. F Vesicular, andesitic glassy material containing abundant plagioclase microlites (polished). (Okupata Tephra, Oa-1, L. Maratoto.) Scale bar $=41 \mu \mathrm{m}$. G Calcium rich, inclusion bearing, plagioclase grain with fragmentary, vesicular andesitic glassy rim (polished). (Eg2 tephra, L. Kainui.) Scale bar $=24 \mu \mathrm{m}$. H Surface of part of moderately vesicular rhyolitic pumice shard (peralkaline) showing surface micropitting. (Tuhua Tephra, L. Rotomanuka.) Scale bar $=8 \mu \mathrm{m}$.

\section{Correlations based on glass chemistry}

The analyses show that the eruptives associated with each volcanic centre can be distinguished by their major element chemistry, particularly using $\mathrm{TiO}_{2}$, $\mathrm{FeO}^{*}$ (total iron), $\mathrm{MgO}$, and $\mathrm{CaO}$, which typically have small standard deviations. In individual eruptives from the Okataina and Taupo Volcanic Centres, the glass major element chemistry is usually insufficient on its own to enable identification of a particular named unit. Rotorua Ash (Okataina) and Whakaipo Tephra (Taupo) appear to differ to some extent in this regard, 


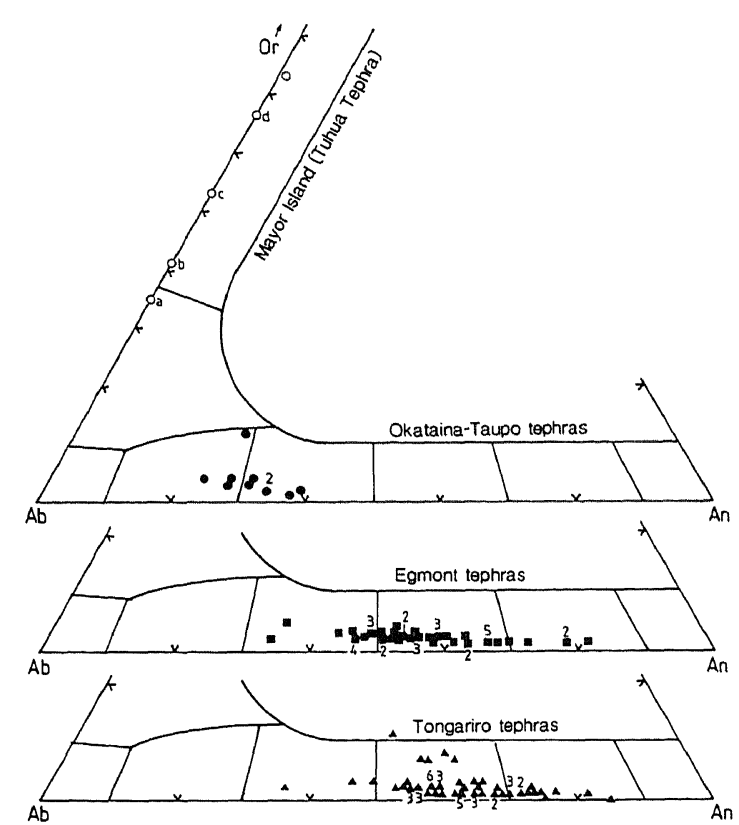

Fig. 10 Electron microprobe analyses of feldspars (mol. $\%)$. Only analyses from grain cores are plotted. Numbers indicate that two or more grains have essentially identical Ab-An-Or compositions. Analyses a-d (Tuhua Tephra) determined by R. M. Briggs (pers. comm. 1987); samples $a$ and $b$ were from a subaerial deposit of Tuhua Tephra on Coromanciel Peninsula. however (Lowe in press). Whakaipo Tephra, rather than Waimihia Lapilli as identified originally by Lowe et al. (1980) from its hypersthene-rich mineralogy, is re-identified here from the slightly lower concentrations of $\mathrm{CaO}$ and $\mathrm{FeO}^{*}$ in its glass (Table 10), and from the new radiocarbon dates obtained for it (c. 2800 years old; Fig. 6). The individual Egmont tephras show some variations in glass chemisty (e.g., Eg-2 cf. Eg-12, Table 10), but such differences are statistically uncertain because of the generally high standard deviations and the low numbers of shards analysed. Variations in $\mathrm{CaO}$ in Tongariro (particularly) and Egmont glasses may relate in part to an effect of plagioclase microlites in the EMP analysis (cf. Reasoner \& Healy 1986).

Correlations with named units can generally only be made using stratigraphic position, ${ }^{14} \mathrm{C}$ age, and other data (e.g., ferromagnesian mineralogy, abundance of feldspar) taken together.

The only eruptive from Mayor Island previously known to have reached the North Island mainland is the c. 6200 year old Tuhua Tephra (Lowe et al. 1980; Hogg \& McCraw 1983). However, the occurrence of a few glass shards of peralkaline composition (Table 10; Fig. 9C) in a tephra c. 14500 years old in Lake Rotomanuka suggests the presence of a second Mayor Island eruptive on the mainland (albeit as a very light dusting in the Waikato).

Puketarata Ash, derived from the Puketarata dome in the Maroa Volcanic Centre (Lloyd 1972; Wilson et al. 1986), is provisionally identified in the cores, mainly on the basis of its slightly unusual

Table 9 Duplicate electron microprobe analyses of three glass shards in Mapara Tephra in a core from Lake Kainui (normalised to $100 \%$ loss free).

\begin{tabular}{|c|c|c|c|c|c|c|c|}
\hline \multirow{2}{*}{$\begin{array}{l}\text { Shard no } \\
\text { analysi }\end{array}$} & \multicolumn{2}{|c|}{1} & \multicolumn{2}{|c|}{2} & \multicolumn{2}{|c|}{3} & \multirow{2}{*}{$\begin{array}{c}\text { Mean } \pm 1 \text { S.D. } \\
(n=6)\end{array}$} \\
\hline & is: a & b & a & b & $\mathbf{a}$ & $\mathrm{b}$ & \\
\hline $\mathrm{SiO}_{2}$ & 77.03 & 77.18 & 76.68 & 76.47 & 76.63 & 76.23 & $76.70 \pm 0.35$ \\
\hline $\mathrm{Al}_{2} \mathrm{O}_{3}^{2}$ & 13.04 & 12.90 & 13.35 & 13.27 & 13.27 & 13.09 & $13.15 \pm 0.17$ \\
\hline $\mathrm{TiO}_{2}^{3}$ & 0.17 & 0.19 & 0.19 & 0.19 & 0.19 & 0.18 & $0.19 \pm 0.01$ \\
\hline $\mathrm{FeO}^{2} *$ & 1.73 & 1.50 & 1.74 & 1.78 & 1.69 & 1.85 & $1.72 \pm 0.12$ \\
\hline $\mathrm{MgO}$ & 0.15 & 0.16 & 0.20 & 0.14 & 0.16 & 0.19 & $0.17 \pm 0.02$ \\
\hline $\mathrm{CaO}$ & 1.24 & 1.20 & 1.30 & 1.29 & 1.25 & 1.47 & $1.29 \pm 0.09$ \\
\hline $\mathrm{Na}_{2} \mathrm{O}$ & 3.56 & 3.79 & 3.44 & 3.75 & 3.84 & 3.98 & $3.73 \pm 0.20$ \\
\hline $\mathrm{K}_{2} \mathrm{O}$ & 2.94 & 2.96 & 2.95 & 2.99 & 2.86 & 2.89 & $2.93 \pm 0.05$ \\
\hline $\mathrm{Cl}^{2}$ & 0.14 & 0.12 & 0.13 & 0.12 & 0.11 & 0.13 & $0.13 \pm 0.01$ \\
\hline Watert & - & - & 0.54 & 1.22 & 1.55 & 0.20 & $0.59 \pm 0.66$ \\
\hline Total & 100.17 & 101.26 & 99.46 & 98.78 & 98.45 & 99.80 & \\
\hline
\end{tabular}

*Total $\mathrm{Fe}$ as $\mathrm{FeO}$.

$\dagger$ Difference between original analytical total (given) and 100.

Each shard was analysed in two different spots: $a, b$ (see text for analytical conditions). 
Table 10 Electron microprobe analyses* of glass in tephras sampled from Lakes Rotomanuka, Kainui, or Maratoto. The analyses are normalised to $100 \%$ volatile free.

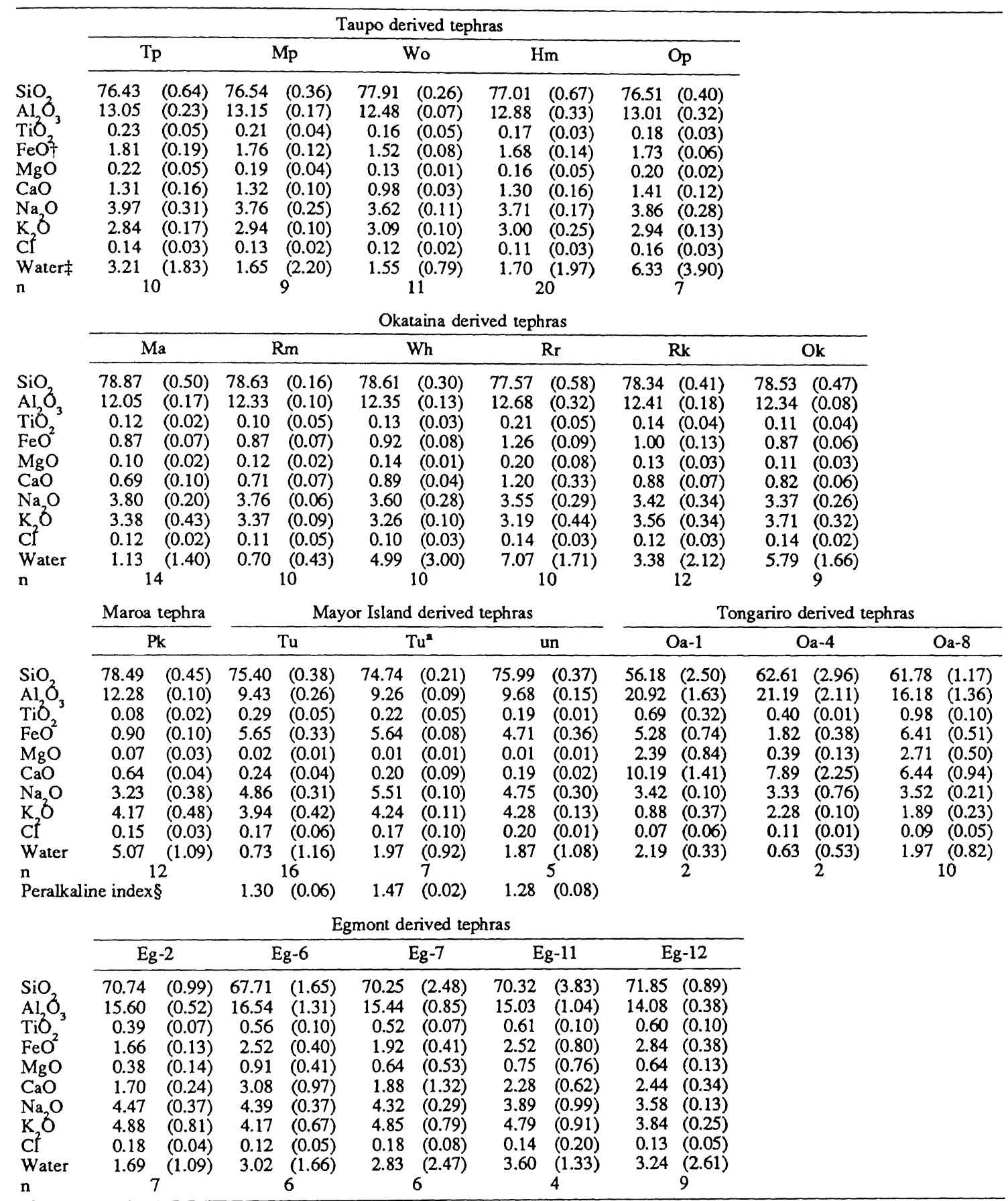

*Analyses made using a $8 \mathrm{nA}$ beam current at $15 \mathrm{kV}$ and defocussed to $10 \mu \mathrm{m}$ (see text). †Total Fe as $\mathrm{FeO}$.

†Difference between original analytical total and 100 . $\$\left[\mathrm{Na}_{2} \mathrm{O}+\mathrm{K}_{2} \mathrm{O}\right] / \mathrm{Al}_{2} \mathrm{O}_{3} ;$ mean $=1.33 \pm 0.1$.

$\mathrm{n}=$ number of analyses in mean; numbers in parentheses $=1$ standard deviation.

Samples Mp, Tu (analyst P. C. Froggatt), Eg-2, Eg-7 from L. Kainui; Oa-1, Oa-8, Eg-11 from L. Maratoto; rest from L. Rotomanuka.

Tephra abbreviations given in Table 1 . 
glass chemistry, in a sample from Lake Rotomanuka. The very low $\mathrm{TiO}_{2}$ and $\mathrm{MgO}$ concentrations (Table 10) correspond to similarly low levels in residual glass of lava from Puketarata dome analysed by Ewart (1969) and Ewart et al. (1968a), and in glass from near-source Puketarata Ash (P. C. Froggatt pers. comm. 1984). Thus the deposits may be correlatives. The shards tentatively identified as representing Puketarata Ash in Lake Rotomanuka occur in a zone stratigraphically between the Rotoaira and Rerewhakaaitu tephras. An age of c. 14000 years is suggested. This stratigraphic position and age is consistent with findings from recent mapping near the Puketarata dome (C. G. Vucetich pers. comm. 1983), although previously the stratigraphic relationship of Puketarata Ash to certain other tephras was ambiguous (see Vucetich \& Pullar 1969, 1973; Topping \& Kohn 1973). The postulated occurrence of Puketarata Ash in the Hamilton Basin seems remarkable, given the very small volume $\left(0.22 \mathrm{~km}^{3}\right)$ and subplinian nature of the deposit (Wilson et al. 1986).

\section{TEPHRA DISTRIBUTION AND IMPLICATIONS}

\section{Distribution of rhyolitic and andesitic tephras}

The relative thicknesses of rhyolitic to andesitic tephras at each lake coring site are plotted in Fig. 11. Generally, andesitic tephras are thickest in the southern part of the study region, decreasing in proportion to the thickening rhyolitic tephras to the east and southeast. For example, at Lake Rotomanuka, the andesitic material comprises c. $35 \%$ of the total thickness of the deposits and, at Lake Ngaroto, c. 36\%. In Lake Okoroire, however, the andesitic component is only c. $6 \%$, although similar numbers of andesitic tephras are present. The proportion of andesitic tephras also diminishes northwards (e.g., the andesitic tephras in Lake Kainui and Leeson's Pond account for c. $15 \%$ and c. $11 \%$, respectively, of the total thickness of tephras in these lakes; see also Lowe 1986b, p. 291). These differences probably reflect changes in distance from the source volcanoes, and the distributional pattern of fallout (e.g., see Fig. 12).

\section{Implications for weathering}

The broad changes in the ratio of andesitic to rhyolitic material across the central Waikato region, based on the lacustrine tephra compositions, support the findings of most studies on the subaerial tephraderived soils-those formed from the so-called "Mairoa Ash" and "Tirau Ash" beds as described earlier (e.g., Grange 1931; Taylor 1933; Hodder \& Wilson 1976; Lowe 1981a). The possible influence of this "compositional gradient" on weathering and argillisation processes in the tephra-derived soils in the central-eastern Waikato area is discussed in Lowe \& Nelson (1983) and Lowe (1986b) (sce also Parfitt et al. 1982b, 1983).

The P.I. values of glass in the lacustrine tephras indicate that the Egmont, Tongariro, and Mayor Island glasses (P.I.s $=71.8-81.7$ ) are more susceptible to weathering than are the Maroa (P.I. = 67.2) or Taupo and Okataina derived glasses (P.I.s = 64.0 - 65.4). This implies that, in tephra studies involving detailed analysis of glass from weathering environments (e.g., Hodder \& Wilson 1976), glasses from these first three centres in particular are liable to be under-represented. Similarly, olivine, which is found in small amounts in some of the Tongariro derived tephras in the lake cores, has not been recorded in any subaerial tephra deposits in the Waikato area (Lowe 1986b), presumably having been rapidly weathered in the soil-forming environment.

\section{Isopach maps and tephra dispersal mechanisms}

On the provisional isopach maps (Fig. 12), the contours are tentative because the number and geographic spread of the sites is relatively limited, and because the tephra thickness measurements may differ by small amounts in cores from the same lake (an average thickness was used in such cases). It is assumed that all of the tephric material is essentially airfall in origin (i.e., it was not overthickened, or thinned, by postdepositional wave action or by erosion from the catchment).

The outer limits of previous isopach maps (e.g., insets in Fig. 12) are generally restricted to c. 100-200 mm thickness contours. The new isopach maps presented here have improved on this degrce of resolution by c. 10-100 times, and include isopachs as thin as 3-5 mm (e.g., Fig. 12B, F). The maps generally conform with the previous ones in that the more distal deposits in the Waikato region are usually thinner than the outermost contours of the earlier maps. For Rotorua Ash, the outermost isopach (c. $200 \mathrm{~mm}$ ) of Pullar \& Birrell (1973a) appears to conflict with the lake measurements (Fig. $12 \mathrm{~J}$, inset). The $300 \mathrm{~mm}$ isopach distribution pattern 
Lake sites are: 1, L. Maratoto; 2, L. Rotomanuka; 3, L. Ngaroto; 4, L. Mangakaware; 5, L. Mangahia; 6, L. Rotoroa; 7, L. Rotokauri (thickness measurements do not include Rerewhakaaitu Ash); 8, L. Kainui; 9, L. Rotokaraka; 10, Leeson's Pond; 11, L. Okoroire; 12, L. Rotongata.

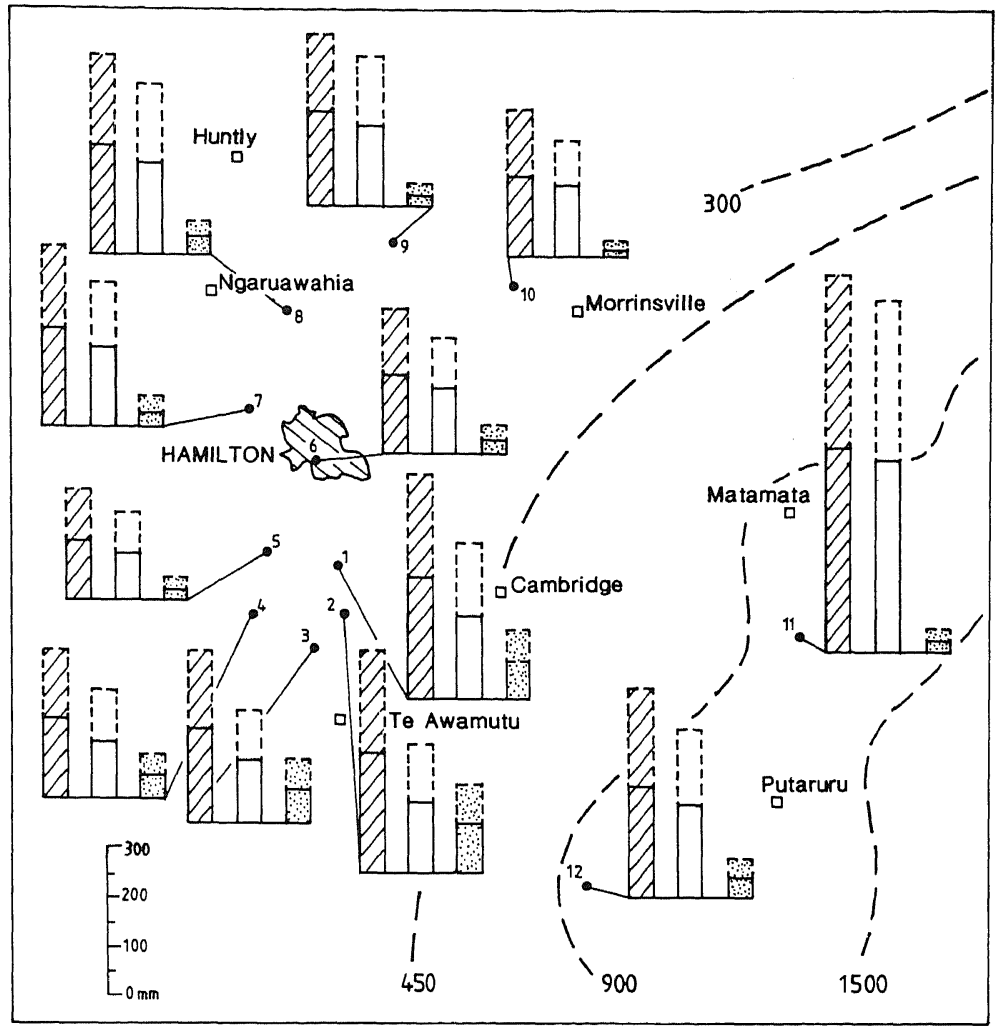

Fig. 11 Tephra thickness-compositional relationships in the Waikato area based on approximate measurements of lacustrine tephras aged $\leq \mathrm{c} .15000$ years (i.e., younger than and including Rerewhakaaitu Ash). Bars with hatching $=$ total thickness of tephras from all sources; blank bars = total thickness of rhyolitic tephras; stippled bars = total thickness of andesitic tephras. Solid bar lines represent actual thickness measurements; dashed bar lines represent thicknesses adjusted for compaction and dissemination to obtain an equivalent dry-land tephra thickness (see text). Dashed lines are isopach contours (in millimetres) of the sum of tephras enupted during the last c. 15000 years, as measured at subaerial sites by Pullar (1967, p. 28).

in Fig. 12J, with a possible northwest-southeast trending fallout axis (arrowed), is more consistent with the lake data, however. In Fig. 12F (Rotoma Ash), the outermost isopach of Pullar \& Birrell (1973a) of $100 \mathrm{~mm}$ may similarly have been overestimated (cf. approx. $55 \mathrm{~mm}$ dry-land equivalent thickness from lake core data).

Graphs showing isopach thicknesses plotted against distance from isopach centre for 12 tephras are given in Fig. 13. These combine the approximate thickness data from the Waikato lake cores with measurements from the previously published isopach maps as referenced in the caption to Fig. 12. The isopach thicknesses are plotted along a transect from the isopach centres towards Hamilton. These transects do not, therefore, necessarily coincide with a major or minor fallout axis (cf. Froggatt 1982b).
Near-linear semilog plots indicate an exponential decrease in tephra thickness $(T)$ with increasing distance $(x)$ from the source (i.e., $T=$ $\mathrm{ae}^{-\mathrm{bx}}$; Fisher \& Schmincke 1984). Various workers have suggested that a change in slope reflects a change in dispersal mechanism of the tephra, perhaps from turbulent transport near the source to normal wind dispersal of finer material further from the source. More recently, however, this flat-lying "fine tail" has been interpreted as representing coignimbrite ashfall rather than Plinian-type fallout material (Sparks \& Walker 1977; Froggatt 1982b; Fisher \& Schmincke 1984). Secondary thickening of distal tephra deposits has also been attributed to premature fallout because of particle aggregation or scavenging (Cas \& Wright 1987). 

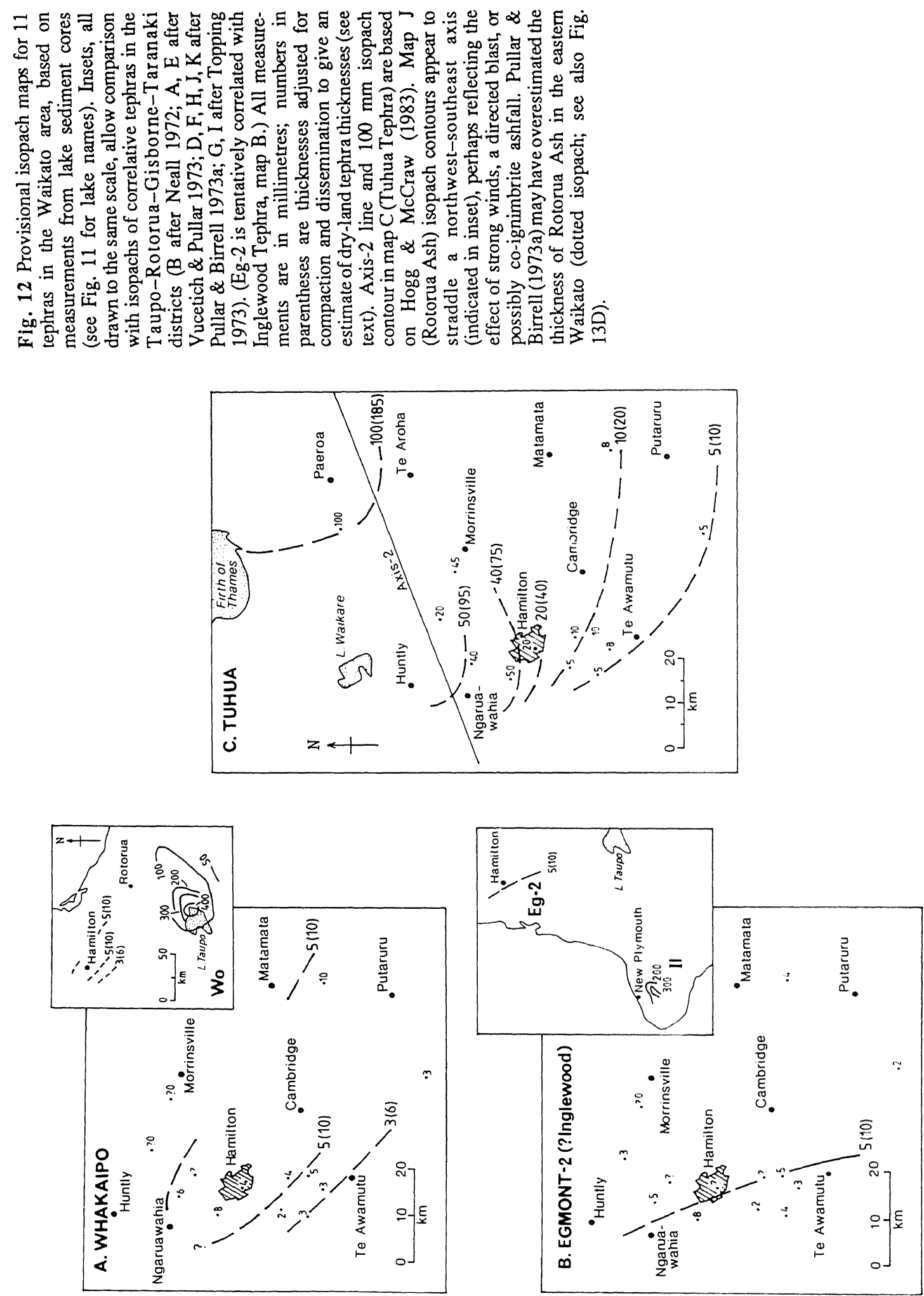

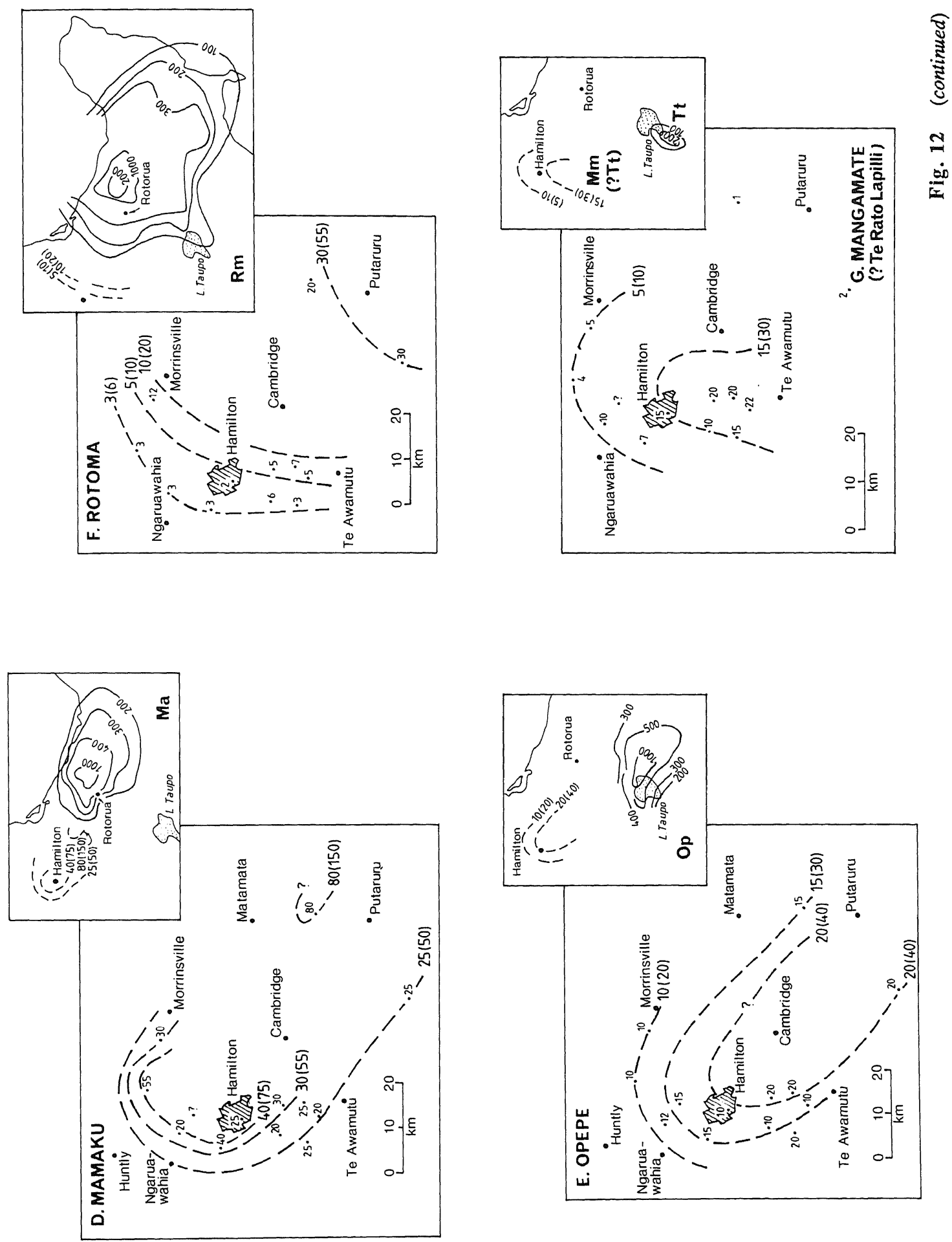

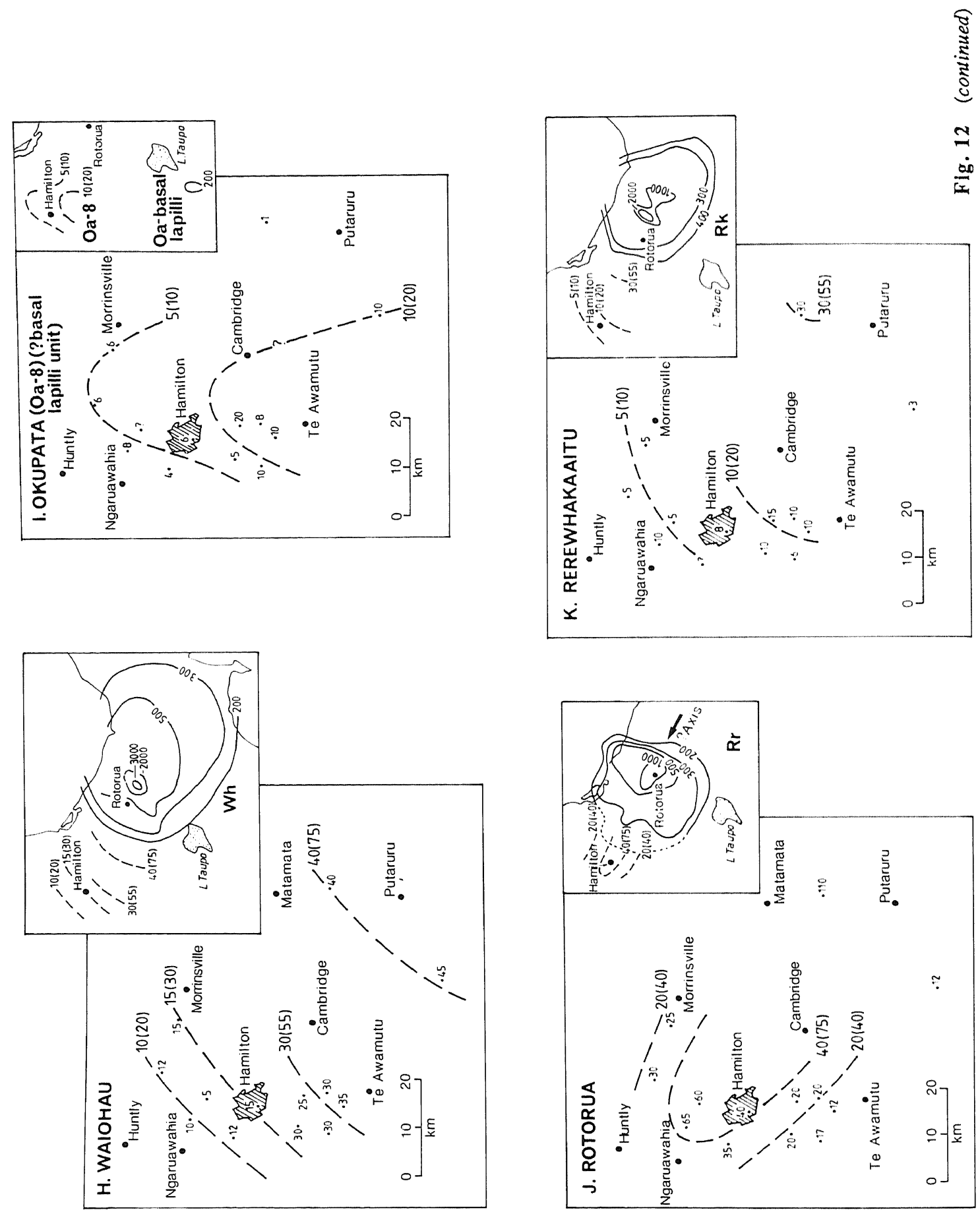


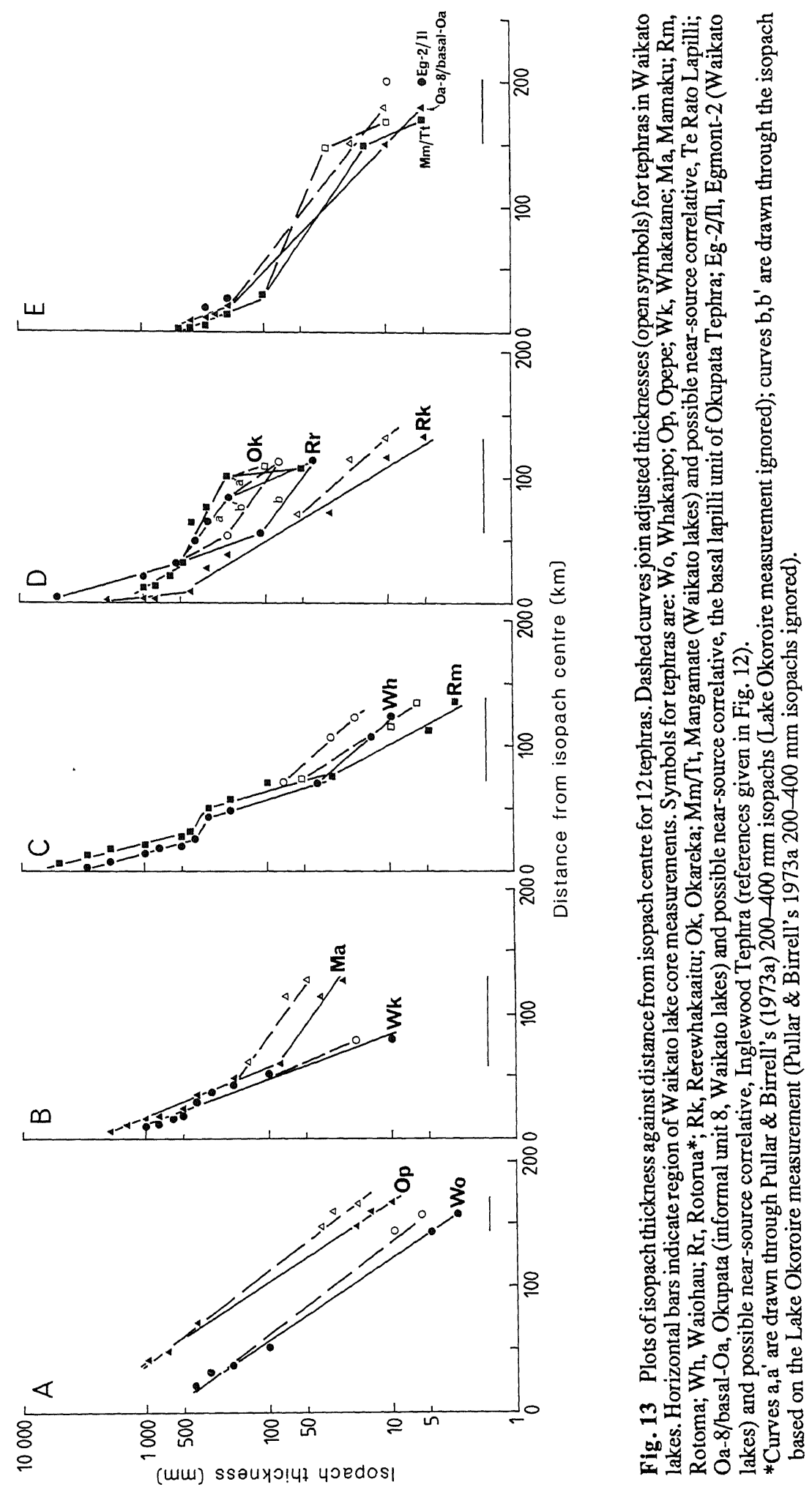


In Fig. 13, some of the plots are approximately linear (with essentially little effective difference in shape between the actual and adjusted thickness plots), and hence generally fit an exponential decay model (e.g., Fig. 13A). However, the distal fallout deposits of other tephras are thicker than the exponential would predict, most probably indicating either a change in dispersal mechanism or a contribution from co-ignimbrite ash associated with the eruptions. Mamaku Ash (Fig. 13B), Rotorua Ash, Rerewhakaaitu Ash, Okareka Ash (Fig. 13D), and possibly Waiohau Ash (Fig. 13C) show this latter pattern to a greater or lesser extent. The Mamaku and Waiohau eruptions included ignimbritic events (Nairn 1981), and Rotorua Ash local near-vent pyroclastic flow and surge events (Nairn 1980), so it is possible that the "fine tail" for these tephras in the Waikato area partly represents co-ignimbrite ash. However, a change in dispersal mechanism cannot be excluded; Nairn (1980) suggested that upper wind vectors varied during the Rotorua eruption sequence. The plots of the Tongariro derived tephras in Fig. 13E also appear to show slope breaks, but more measurements at intermediate sites are needed to corroborate this.

Tuhua Tephra (not plotted in Fig. 13) is thickest to the NNE of Hamilton City, but drops off markedly to the south (Fig. 12C). The Waikato lakes' measurements generally support the onland distribution pattern in Hogg \& McCraw (1983), which shows a postulated depositional axis extending southwestwards from Mayor Island and passing to the north of Hamilton. Tuhua Tephra has recently been identified in Rotorua City, c. 5-10 mm thick (Kennedy \& Froggatt 1984).

The curves in Fig. 13 suggest that many of the tephras found in the Waikato lakes are likely to persist well beyond the Waikato area. Extrapolation of the graphs indicate that for the Taupo and Okataina derived tephras, the c. $1 \mathrm{~mm}$ isopach is likely to occur c. $200-250 \mathrm{~km}$ from the source (probably c. $300 \mathrm{~km}$ or so for Mamaku Ash); for the andesitic tephras, the c. $1 \mathrm{~mm}$ isopach could occur c. $250-300 \mathrm{~km}$ from the source.

\section{Possible dispersal mechanisms}

The central Waikato area lies c. $70-200 \mathrm{~km}$ from the tephra source volcanoes, and a good proportion of the distal lacustrine tephras present relate to relatively minor deposits (in terms of thickness) near the source. Consequently, their deposition in the Waikato area must depend on certain eruption conditions or wind regimes applying.
Although the prevailing winds in the North Island are presently southwesterly-westerly (and are likely to have been so for at least the past c. 20000 years, e.g., Salinger 1984; Stewart \& Neall 1984), the predominant wind direction at altitudes greater than c. $20 \mathrm{~km}$ is usually easterly (Nelson et al. 1985; Buck 1985). Thus, one explanation for the deposition of many of the late Quaternary tephras in Waikato is that they derive largely from eruptions that were powerful enough to produce eruption columns exceeding c. $20 \mathrm{~km}$ in height (the dispersion of tephras being mainly a function of column height and the atmospheric wind regime, e.g., Walker 1981a; Wilson et al. 1978; SamaWojcickietal. 1981). This was evidently the case for the "ultraplinian" Taupo eruption (Walker 1980) and the Tuhua eruption (Buck 1985; Houghton \& Wilson 1986), and possibly for the Rotorua and Hinemaiaia eruptions (Nairn 1980; Lowe 1986a), at least (see also Wilson et al. 1986). The possible role of water-magma interactions in producing very powerful (phreatomagmatic) eruptions may also be relevant (cf. Walker 1981a).

Some of the tephras may have originated from less powerful eruptions but were ejected obliquely (directed blasts) or were emplaced by strong northeasterly, southeasterly, or southwesterly lower atmosphere winds. Strong southerly winds blowing during the modest February 1975 eruption of $\mathrm{Mt}$ Ngauruhoe resulted in fine ash being deposited as far north as Hamilton and Tauranga Cities (Nairn \& Self 1978). (Ash from this eruption has not been detected in the Waikato lakes.) The curves in Fig. 13E suggest that such winds may have been responsible for depositing Mangamate and Okupata (Oa-8) eruptives in the central Waikato lake sites (see also Topping 1973).

A number of known rhyolitic eruptives from the Taupo and Okataina volcanoes do not appear to be present as macroscopic tephras in the Waikato lakes studied: the Kaharoa* (Okataina) and the Waimihia, Motutere, Poronui, and Karapiti (Taupo) tephras. Eruptions producing two of these (Kaharoa and Waimihia) were evidently quite powerful but probably strongly controlled by contemporary winds (Pullar et al. 1977; Walker 1981b). The other eruptions were moderate to weak in nature, producing plinian or subplinian deposits (Vucetich \& Pullar 1973; Froggatt 1981b, c; Froggatt \& Solloway 1986; Wilson et al. 1986).

Evidently, eruptions represented by substantial deposits near the source will not necessarily persist far (nor in all directions), whereas apparently minor 
deposits near the source may represent powerful sheet-forming eruptions and be widely dispersed as inconspicuous layers (see Walker 1973, 1981c; Fisher \& Schmincke 1984).

\section{TEPHRA ACCUMULATION RATE}

The average rate of accumulation of tephras in the Waikato area over the last c. 17000 years has been approximately one event per c. 400 years. Rhyolitic tephras are deposited, on average, once every c. 1100 years. Andesitic tephras are deposited more frequently, every c. 650 years on average, but in relatively concentrated bursts of activity, especially from Tongariro. Based on the average depositional rate of one event per c. 400 years, the central Waikato area can possibly expect to receive a "significant" ash fallout event (i.e., substantial enough to be recorded in the lake sediments) at any time because the last such event recorded was deposited c. 1800 years ago (Taupo Pumice). It is hard to say which volcanic centre is likely to produce this next event because all can be considered potentially active and capable of producing a widespread deposit under certain conditions (see Froggatt 1982b; Dibble \& Neall 1984; Latter 1986). The Maroa Centre, with only one relatively small eruption in the past c. 17000 years, might be considered least likely, but such a low frequency does not preclude the possibility of a large, widespread eruption in the near future. A similar comment probably applies to Mayor Island as only one major plinian tephra is known on the island (Houghton \& Wilson 1986). For the reasons outlined previously, any tephra erupted from one of the six volcanic centres in question may not be carried to the Waikato area in significant quantities. However, because the lake record represents approximately $60 \%$ of the known major tephraproducing eruptions (e.g., McCraw 1975; Cole \& Nairn 1975), there is perhaps a better than even

\footnotetext{
* Kaharoa Ash probably occurs in northeastern Waikato, being tentatively identified in surficial peat deposits at three localities: the Hauraki bog (Lowe et al. 1981; Hogg \& McCraw 1983); the Pohlen bog (near Matamata); and an unnamed bog in the Kaimai Range (Lowe 1987). Its apparent absence in the Lake Okoroire cores (Fig. 2) may be attributable to the difficulty of coring the very sloppy surficial lake sediments. Close inspection of all the cores taken from the other lakes has, so far, revealed no trace of Kaharoa Ash.
}

chance that another significant eruption from any of these volcanic centres will result in tephra fallout in the Waikato area. Such a tephra fall in Waikato, even if only a few millimetres thick, would probably severely disrupt transport and communication systems and energy and water supplies, immobilise machinery, and damage crops (Blong 1984; Dibble \& Neall 1984).

\section{TEPHROCHRONOLOGICAL APPLICATIONS TO PALEO- ENVIRONMENTAL STUDIES}

The Waikato lakes are attractive for paleoenvironmental studies because: (1) most are c. 16 000-17 000 years old and hence provide a record of both late-glacial and postglacial changes in the lakes and their catchments; and (2) the dated tephras contained in their sediments provide an exceptionally detailed and, within the constraints of ${ }^{14} \mathrm{C}$ dating, accurate time-stratigraphic framework. Paleolimnological studies using the tephras as marker beds began comparatively recently and are summarised in Lowe \& Green (1987). Further multidisciplinary studies are in progress.

\section{SUMMARY}

Cores from 14 Waikato lakes have provided a new record of tephra deposition in the Waikato area over the past c. 17000 years. Forty-one distal tephras of rhyolitic or andesitic composition have been identified (Table 1). They originated from six North Island volcanic centres as follows: Taupo, 5 tephras (Taupo, Mapara, Whakaipo, Hinemaiaia, and Opepe); Okataina, 7 tephras (Whakatane, Mamaku, Rotoma, Waiohau, Rotorua, Rerewhakaaitu, and Okareka); Maroa, 1 tephra (Puketarata); Mayor Island, 2 tephras (Tuhua and uncorrelated); Tongariro, 11 tephras (Mangamate, Okupata [8 informal units, Oa-1 to Oa-8], uncorrelated, and Rotoaira); Egmont, 15 tephras (15 informal units, Eg-1 to Eg-15). These sources and correlations were distinguished using the tephras' mineralogy and composition (Table 3) together with stratigraphic position and ${ }^{14} \mathrm{C}$ chronology (Fig. 2, 6).

In terms of thickness, the rhyolitic tephras predominate at all sites, but the proportion of andesitic to rhyolitic eruptives differs across the region: c. $30-35 \%$ in the south, c. $10-15 \%$ in the 
north, and c. 5\% in the east (Fig. 11). The compositional variations associated with these differences may have influenced weathering and argillisation in the late Quaternary tephra derived soils in the region (Lowe 1986b).

In the Ohaupo-Hamilton area, the total thickness of the lacustrine tephras younger than c. 15 000 years is c. $25 \mathrm{~cm}$ (approx. equivalent to $\mathrm{c} .47 \mathrm{~cm}$ on dry land); in the Whitikahu-Morrinsville area, the thickness is c. $20 \mathrm{~cm}(\mathrm{c} .37 \mathrm{~cm})$; and near Tirau the thickness is c. $42 \mathrm{~cm}$ (c. $78 \mathrm{~cm}$ ).

Provisional isopach maps are given for 11 of the tephras in the central Waikato area (Fig. 12). Isopach thickness-distance plots show some tephras to have an exponential rate of thickness decrease away from source; others have an "overthickened" fine tail possibly reflecting either a change in dispersal mechanism (e.g., strong directional surficial or high altitude winds) or the addition of co-ignimbrite ash.

The tephras preserved by the lake sediments are useful as time-stratigraphic markers in multidisciplinary paleoenvironmental studies in the Waikato area.

\section{ACKNOWLEDGMENTS}

I am pleased to thank the following University of Waikato colleagues who have assisted in various ways in this study: J.D. Green, C. H. Hendy, B. McCabe, and J. A. T. Boubée (lake coring); A. G. Hogg and V. Blair ( ${ }^{14} \mathrm{C}$ dating); R. M. Briggs and M. Storey (mineralogy and EMP analysis); and C. K. Beltz (SEM). I was greatly helped by P. C. Froggath, G. J. Gosson, K. Palmer, and J. Carter in obtaining the electron microprobe data at the Analytical Facility, Victoria University of Wellington. Dr Froggatt also generously provided unpublished reference analyses of glass from rhyolitic tephras sampled near the source. I am appreciative of support and assistance from J. D. McCraw and A.P. W. Hodder (University of Waikato), V.E.Neall, R. B. Stewart C. G. Vucetich, R. C. Wallace, and B. V. Alloway (Massey University), I. A. Naim (N.Z. Geological Survey), B.P. Kohn (Ben Gurion Universityof the Negev), J.A. Westgate (University of Toronto), and R. H. King (University of Western Ontario). S. Wright and E. Norton are also especially thanked for typing the manuscript.

\section{REFERENCES}

Anderson, D. J.; Lindsley, D. H. 1985: New (and final!) models for the Ti-magnetite/ilmenite geothermometer and oxygen barometer. EOS 66: 416.

Anderson, R.Y.; Nuhfer, E. B.; Dean, W.E. 1984: Sinking of volcanic ash in uncompacted sediment in Williams Lake, Washington. Science 225: 505-508.
Blong, R. J. 1984: Volcanic hazards. North Ryde, Academic Press. 424 p.

Borchardt, G. A.; Norgren, J. A.; Harward, M. E. 1973: Correlation of ash layers in peat bogs of eastern Oregon. Geological Society of America bulletin 84: 3101-3108.

Boubée, J. A. T. 1983: Past and present benthic fauna of Lake Maratoto with special reference to the Chironomidae. Unpublished D.Phil. thesis, lodged in the Library, University of Waikato, Hamilton.

Buck, M. D. 1985: An assessment of volcanic risk on and from Mayor Island, New Zealand. New Zealand journal of geology and geophysics 28: 283-298.

Buck, M. D.; Briggs, R. M.; Nelson, C. S. 1981: Pyroclastic deposits and volcanic history of Mayor Island. New Zealand journal of geology and geophysics 24: 449-467.

Buddington, A. F.; Lindsley, D. H. 1964: Iron-titanium oxide minerals and synthetic equivalents. Journal of petrology 5: 310-357.

Carmichael, I. S. E. 1967: The iron-titanium oxides of salic volcanic rocks and their associated ferromagnesian silicates. Contributions to mineralogy and petrology $14: 36-64$.

Cas, R. A. F.; Wright, J. V. 1987: Volcanic successions. London, Allen \& Unwin. 528 p.

Clark, R. H. 1960: Petrology of the volcanic rocks of Tongariro subdivision. In: Gregg, D. R. The geology of Tongariro subdivision. Appendix 2. New Zealand Geological Survey bulletin 40: 107-123.

Cole, J. W. 1970: Description and correlation of Holocene volcanic formations in the TaraweraRerewhakaaitu region. Transactions of the Royal Society of New Zealand earth sciences 8: 93-108.

1978: Andesites of the Tongariro Volcanic Centre, North Island, New Zealand. Journal of volcanology and geothermal research 3: 121-153.

Cole, J. W.; Naim, I. A. 1975: Catalogue of the active volcanoes and solfatara fields of New Zealand. International Association of Volcanology and Chemistry of the Earth's Interior 22: 156 p.

Cole, J.W.; Graham, I. J.; Hacketh, W. R.; Houghton, B. F. 1986: Volcanology and petrology of the Quaternary composite volcanoes of the Tongariro Volcanic Centre, Taupo Volcanic Zone. Royal Society of New Zealand bulletin 23: 224-250.

Cowie, J. D.; Milne, J. D. G. 1973: Maps and sections showing the distribution and stratigraphy of North Island loess and associated cover deposits, New Zealand. New Zealand soil survey report 6.

Currie, D. R. 1981: Radiocarbon dating applied to tephras. In: Howorth, R. et al. ed. Proceedings of tephra workshop. Geology Department Victoria University of Wellington publication 20: 13-20. 
Davis, J. O. 1985: Correlation of late Quaternary tephra layers in a long pluvial sequence near Summer Lake, Oregon. Quaternary research 23: 38-53.

Davoren, A. 1978: A survey of New Zealand peat resources. Water and soil technical publication 14.

Deer, W. A.; Howie, R. A.; Zussman, J. 1963: Rockforming minerals. Vol. 2. Chain silicates. London, Longmans. 379 p.

Dibble, R. R.; Neall, V.E. 1984: Volcanichazards in New Zealand. Pp. 332-374 in: Speden, I. G.; Crozier, M. J. conv. Natural hazards in New Zealand. New Zealand National Commission for UNESCO, Wellington.

Edmondson, W. T. 1984: Volcanic ash in lakes. Northwest environmental journal 1: 139-150.

Ewart, A. 1963: Petrology and petrogenesis of the Quaternary pumice ash in the Taupo area, New Zealand. Journal of petrology 4: 392-431.

1969: Petrochemistry and feldspar crystallisation in the silicic volcanic rocks, central North Island, New Zealand. Lithos 2: 371-388.

1971: Notes on the chemistry of ferromagnesian phenocrysts from selected volcanic rocks, Central Volcanic Region. New Zealand journal of geology and geophysics 14: 323-340.

Ewart, A.; Taylor, S. R.; Capp, A. C. 1968a: Trace and minor element geochemistry of rhyolitic volcanic rocks, central North Island, New Zealand-total rock and residual liquid data. Contributions to mineralogy and petrology 18: 76-104.

1968b: Geochemistry of pantellerites of Mayor Island, New Zealand. Contributions to mineralogy and petrology 17: 116-140.

Federman, A. N.; Carey, S. N. 1980: Electron microprobe correlation of tephra layers from eastern Mediterranean abyssal sediments and the island of Santorini. Quaternary research 13: 160-171.

Federman, A. N.; Scheidegger, K. F. 1984: Compositional heterogeneity of distal tephra deposits from the 1912 eruption of Novarupta, Alaska. Journal of volcanology and geothermal research 21: 233-254.

Fisher, R. V.; Schmincke, H. -U. 1984: Pyroclastic rocks. Berlin, Springer-Verlag. $472 \mathrm{p}$.

Franks, A. M. 1984: Soils of Eltham County and the tephrochronology of central Taranaki. Unpublished Ph.D. thesis, lodged in the Library, Massey University, Palmerston North.

Froggatt, P.C. 1981a: Review of Holocene eruptions from Taupo. In: Howorth, R. et al. ed. Proceedings of tephra workshop. Geology Department Victoria University of Wellington publication 20: 21-28. 1981b: Karapiti Tephra Formation: a 10000 years B.P. rhyolitic tephra from Taupo. New Zealand journal of geology and geophysics 24: 95-98. 1981c: Motutere Tephra Formation and redefinition of Hinemaiaia Tephra Formation, Taupo Volcanic Centre, New Zealand. New Zealand journal of geology and geophysics 24: 99-105.

1981d: Stratigraphy and nature of Taupo Pumice Formation. New Zealand journal of geology and geophysics 24: 231-248.

1982a: A study of some aspects of the volcanic history of the Lake Taupo area, North Island, New Zealand. Unpublished Ph.D. thesis, lodged in the Library, Victoria University of Wellington, Wellington.

1982b: Review of methods of estimating rhyolitic tephra volumes; applications to the Taupo Volcanic Zone, New Zealand. Journal of volcanology and geothermal research 14 : 301-318.

1983: Tow ard a comprehensive Upper Quaternary tephra and ignimbrite stratigraphy in New Zealand using electron microprobe analysis of glass shards. Quaternary research 19: 188-200.

Froggatt, P. C.; Gosson, G. J. 1982: Techniques for the preparation of tephra samples for mineral and chemical analysis and radiometric dating. Geology Department Victoria University of Wellington publication 23.

Froggatt, P. C.; Solloway, G. J. 1986: Correlation of Papanetu Tephra to Karapiti Tephra, central North Island, New Zealand. New Zealand journal of geology and geophysics 29: 303-313.

Gibbs, H. S.; Lowe, D. J.; Hogg, A. G. 1982: Parent materials of yellow-brown loams in the Waikato-Coromandel district. Pp. 12-13 in: Neall, V. E. ed. Yellow-brown loams. Lower Hutt, New Zealand Society of Soil Science.

Gow, A. J. 1968: Petrographic and petrochemical studies of Mt Egmont andesites. New Zealand journal of geology and geophysics 11: 166-190.

Gradwell, M. W. 1982: Physical properties of yellowbrown loams. Pp. 54-55 in: Neall, V. E. ed. Yellow-brown loams. Lower Hutt, New Zealand Society of Soil Science.

Grange, L. I. 1931: Volcanic-ash showers. New Zealand journal of science and technology 12: 228-240.

Grange, L. I.; Taylor, N. H. 1932: The distribution and field characteristics of bush-sick soils. New Zealand Department of Scientific and Industrial Research bulletin 32: 21-35.

Grange, L. I.; Taylor, N.H.; Sutherland, C.F.; Dixon, J. K.; Hodgson, L.; Seelye, F. T.; Kidson, E.; Cranwell,L.M.; Smallfield,P.W. 1939: Soils and agriculture of part of Waipa County. New Zealand Department of Scientific and Industrial Research bulletin 76 . 
Green, J. D. 1979: Palaeolimnological studies on Lake Maratoto, North Island, New Zealand. In: Horie, S. ed. Paleolimnology of Lake Biwa and the Japanese Pleistocene 7: 416-438.

Green, J. D.; Lowe, D. J. 1985: Stratigraphy and development of c. 17000 year old Lake Maratoto, North Island, New Zealand, with some inferences about postglacial climatic change. New Zealand journal of geology and geophysics 28: 675-699.

Healy, J. 1964: Stratigraphy and chronology of late Quaternary volcanic ash in Taupo, Rotorua, and Gisborne districts. Part 1. New Zealand Geological Survey bulletin 73: 7-42.

Heiken, G.; Wohletz, K. 1985: Volcanic ash. Berkley and Los Angeles, California, University of California Press. 246 p.

Hodder, A. P. W.; Wilson, A. T. 1976: Identification and correlation of thinly bedded tephra: the Tirau and Mairoa Ashes. New Zealand journal of geology and geophysics 19: 663-682.

Hogg, A. G.; McCraw, J. D. 1983: Late Quatemary tephras of Coromandel Peninsula, North Island, New Zealand: a mixed peralkaline and calcalkaline tephra sequence. New Zealand journal of geology and geophysics 26: 163-187.

Hogg, A. G.; Lowe, D. J.; Hendy, C. H. 1987: University of Waikato radiocarbon dates I. Radiocarbon 29: 263-301.

Houghton, B. F.; Wilson, C. J. N. 1986: Explosive rhyolitic volcanism: the case studies of Mayor Island and Taupo volcanoes. New Zealand Geological Survey record 12: 33-100.

Howorth, R.; Froggatt, P. C.; Robertson, S. M. 1980: Late Quatemary volcanic ash stratigraphy of the Poukawa area, central Hawke's Bay, New Zealand. New Zealand journal of geology and geophysics 23: 487-491.

Howorth, R.; Froggatt, P.C.; Vucetich, C. G.; Collen, J.D. ed. 1981: Proceedings of tephra workshop. Geology Department Victoria University of Wellington publication 20: 1-4.

Hume, T. M.; Nelson, C. S. 1982: X-ray diffraction analytical procedures and some mineralogical characteristics for South Auckland region sediments and sedimentary rocks, with special reference to their clay fraction. Earth Sciences Univer sity of Waikato occasional report 10.

Juvigné, E.; Porter, S. C. 1985: Mineralogical variations within two widespread Holocene tephra layers from Cascade Range volcanoes, U.S.A. Géographie physique et Quaternaire 39: 7-12.

Kennedy, N. M.; Froggath, P. C. 1984: Recognition of Tuhua Tephra (c. 6,200 B.P.) at Rotorua. Geological Society of New Zealand newsletter 66: $17-18$

King, R. H.; Kingston, M. S.; Barneth, R. L. 1982: A numerical approach toward the classification of magnetites from tephra in southern Alberta. Canadian journal of earth science 19: 2012-2019.

Kirkman, J. H.; McHardy, W. J. 1980: A comparative study of the morphology, chemical composition and weathering of rhyolitic and andesitic glass. Clay minerals 15: 165-173.

Kohn, B. P. 1970: Identification of New Zealand tephralayers by emission spectrographic analysis of their titanomagnetites. Lithos 3: 361-368.

1973: Studies of New Zealand Quaternary pyroclastic rocks. Unpublished Ph.D. thesis, lodged in the Library, Victoria University of Wellington, Wellington.

1979: Identification and significance of a late Pleistocene tephra in Canterbury district, South Island, New Zealand. Quaternary research 11: 78-92.

Kohn, B. P.; Glasby, G. P. 1978: Tephra distribution and sedimentation rates in the Bay of Plenty, New Zealand. New Zealand journal of geology and geophysics 21: 49-70.

Kohn, B. P.; Neall, V. E. 1973: Identification of late Quaternary tephras for dating Taranaki lahar deposits. New Zealand journal of geology and geophysics 16: 781-792.

Latter, J. H. 1986: Volcanic risk and surveillance in New Zealand. New Zealand Geological Survey record 10: 5-22.

Leake, B. E. 1978: Nomenclature of amphiboles. Canadian mineralogist 16: 501-520.

Lloyd, E. F. 1972: Geology and hot springs of Orakeikorako. New Zealand Geological Survey bulletin 85 .

Lowe, D. J. 1979: Aspects of the genesis and classification of volcanic-ash soils, Hamilton Basin. New Zealand soil news 27: 171-173.

1981a: Origin and composite nature of late Quaternary air-fall deposits, Hamilton Basin, New Zealand. Unpublished i 1 .Sc. thesis, lodged in the Library, University of Waikato, Hamilton. 1981b: Late Quatemary tephras in the Hamilion Basin, North Island, New Zealand. In: Howorth, R. et al. ed. Proceedings of tephra workshop. Geology Department Victoria University of Wellington publication 20: 67-73.

1985: Application of impulse radar to continuous profiling of tephra-bearing lake sediments and peats: an initial evaluation. New Zealand journal of geology and geophysics 28: 667-674.

1986a: Revision of the age and stratigraphic relationships of Hinemaiaia Tephra and Whakatane Ash, North Island, New Zealand, using distal occurrences in organic deposits. New Zealand journal of geology and geophysics 29: 61-73.

1986b: Controls on the rates of weathering and clay mineral genesis in airfall tephras: a review 
and New Zealand case study. Pp. 265-330 in: Colman, S. M.; Dethier, D. P. ed. Rates of chemical weathering of rocks and minerals. Orlando, Academic Press.

1987: Studies on late Quaternary tephras in the Waikato and other regions in northern North Island, New Zealand, based on distal deposits in lake sediments and peats. Unpublished D.Phil thesis, lodged in the Library, University of Waikato, Hamilton.

- in press: Late Quaternary volcanism in New Zealand: towards an integrated record using distal airfall tephras in lakes and bogs. Journal of Quaternary science 3.

Lowe, D. J.; Green, J. D. 1987: Origins and development of the lakes. In: Viner, A. B. ed. Inland waters of New Zealand. New Zealand Department of Scientific and Industrial Research bulletin 241: $1-64$.

Lowe, D. J.; Hogg, A. G. 1986: Tephrostratigraphy and chronology of the Kaipo Lagoon, an 11,500 yearold montane peat bog in Urewera National Park, New Zealand. Journal of the Royal Society of New Zealand 16: 25-41.

Lowe, D. J.; Nelson, C. S. 1983: Guide to the nature and methods of analysis of the clay fraction of tephras from the South Auckland region, New Zealand. Earth Sciences University of Waikato occasional report 11.

Lowe, D. J.; Hogg, A. G.; Green, J. D.; Boubée, J. A. T. 1980: Stratigraphy and chronology of late Quatemary tephras in Lake Maratoto, Hamilton, New Zealand. New Zealand journal of geology and geophysics 23: 481-485.

Lowe, D. J.; Hogg, A. G.; Hendy, C. H. 1981: Detection of thin tephra deposits in peat and organic lake sediments by rapid X-radiography and X-ray fluorescence techniques. In: Howorth, R. et al.ed. Proceedings of tephra workshop. Geology Department Victoria University of Wellington publication 20: 74-77.

McCraw, J. D. 1967: The surface features and soil pattern of the Hamilton Basin. Earth science journal 1: $59-74$.

1975: Quaternary airfall deposits of New Zealand. Royal Society of New Zealand bulletin 13:35-44.

McGlone, M. S. 1983: Holocene pollen diagrams, Lake Rotorua, North Island, New Zealand. Journal of the Royal Society of New Zealand 13: 53-65.

Mathewes, R. W.; Westgate, J. A. 1980: Bridge River tephra: revised distribution and significance for detecting old carbon errors in radiocarbon dates of limnic sediments in southem British Columbia. Canadian journal of earth sciences 17: 1454-1461.

Nairn, I. A. 1980: Source, age, and eruptive mechanisms of Rotorua Ash. New Zealand journal of geology and geophysics 23: 193-207.
-1981: Some studies of the geology, volcanic history, and geothermal resources of the Okataina Volcanic Centre, Taupo Volcanic Zone, New Zealand. Unpublished Ph.D. thesis, lodged in the Library, Victoria University of Wellington, Wellington.

Nairn, I. A.; Self, S. 1978: Explosive eruptions and pyroclastic avalanches from Ngauruhoe in February, 1975. Journal of volcanology and geothermal research 3: 39-60.

Neall, V. E. 1972: Tephrochronology and tephrostratigraphy of western Taranaki (N108-109), New Zealand. New Zealand journal of geology and geophysics 15: 507-557.

1977: Genesis and weathering of Andosols in Taranaki, New Zealand. Soil science 123: $400-408$.

Neall, V. E.; Alloway, B. V. 1986: Quaternary volcaniclastics and volcanic hazards of Taranaki. New Zealand Geological Survey record 12: 101-137.

Neall, V. E.; Stewart, R. B.; Smith, I. E. M. 1986: History and petrology of the Taranaki volcanoes. Royal Society of New Zealand bulletin 23: 251-263.

Nelson, C. S.; Froggatt, P. C.; Gosson, G. J. 1985: Nature, chemistry and origin of late Cenozoic megascopic tephras in Leg 90 cores from the southwest Pacific. In: Kennett, J.P.; von der Borch, C.C. et al. Initial reports of the Deep Sea Drilling Project 90: 1161-1173.

N.Z. Soil Bureau 1954: General survey of the soils of North Island, New Zealand. New Zealand Soil Bureau bulletin 5 .

Orbell, G. E. 1982: Yellow-brown loams of the Waikato area. Pp. 25-29 in: Neall, V.E. ed. Yellow-brown loams. Lower Hutt, New Zealand Society of Soil Science.

Parfitt, R. L.; Robertson, S. M.; Orbell, G. E. 1982a: Soil stratigraphy of Kereone, Ohaupo and Mairoa soils in the Waikato and Te Kuiti districts. Pp. 13-16 in: Neall, V. E. ed. Yellow-brown loams. Lower Hutt, New Zealand Society of Soil Science.

Parfitt, R. L.; Russell, M.; Kirkman, J. H. 1982b: The clay mineralogy of yellow-brown loam soils. Pp. 48-53 in: Neall, V. E. ed. Yellow-brown loams. Lower Hutt, New Zealand Society of Soil Science.

Parfitt, R.L.; Russell, M.; Orbell, G. E. 1983: Weathering sequence of soils from volcanic ash involving allophane and halloysite. Geoderma 29: 41-57.

Parker, A. 1970: An index of weathering for silicate rocks. Geological magazine 107: 501-504.

Pullar, W. A. 1967: Volcanic ash beds in the Waikato district. Earth science journal 1: 17-30.

1978: Tirau "Ash"-Comment. New Zealand journal of geology and geophysics 21: 271-272. 
Pullar, W. A.; Birrell, K. S. 1973a: Age and distribution of late Quaternary pyroclastic and associated cover deposits of the Rotorua and Taupo area, North Island, New Zealand. New Zealand soil survey report 1.

1973b: Parent materials of Tirau silt loam. New Zealand journal of geology and geophysics 16 : 677-686.

Pullar, W. A.; Heine, J. C. 1971: Ages, inferred from ${ }^{14} \mathrm{C}$ dates, of some tephra and other deposits from Rotorua, Taupo, Bay of Plenty, Gisborne and Hawke's Bay districts. Lower Hutt, Proceedings Radiocarbon Users' Conference. Pp. 117-138.

Pullar, W. A.; Birrell, K. S.; Heine, J. C. 1973: Named tephras and tephra formations occurring in the central North Island, with notes on derived soils and buried paleosols. New Zealand journal of geology and geophysics 16: 497-518.

Pullar, W. A.; Kohn, B. P.; Cox, J. E. 1977: Air-fall Kaharoa Ash and Taupo Pumice, and sea-rafted Loisels Pumice, Taupo Pumice, and Leigh Pumice in northern and eastern parts of the North Island, New Zealand. New Zealand journal of geology and geophysics 20: 697-717.

Reasoner, M. A.; Healy, R. E. 1986: Identification and significance of tephras encountered in a core from Mary Lake, Yoho National Park, British Columbia. Canadian journal of earth science 23: 1991-1999.

Riehle, J. R. 1985: A reconnaissance of the major Holocene tephra deposits in the Cook Inlet region, Alaska. Journal of volcanology and geothermal research 26: 37-74.

Rowley, J. R.; Dahl, A. O. 1956: Modifications in design and use of the Livingstone piston sampler. Ecology 37: 849-851.

Salinger, M. J. 1984: New Zealand climate: The last 5 million years. Pp. 131-150 in: Vogel, J. C. ed. Late Cainozoic palaeoclimates of the Southern Hemisphere. Rotterdam, A. A. Balkema.

Sarna-Wojcicki, A. M.; Shipley, S.; Waith, R. B. jun.; Dzurisin, D.; Wood, S. H. 1981: Areal distribution, thickness, mass, volume, and grain size of air-fall ash from the six major eruptions of 1980. In: Lipman, P.W.; Mullineaux, D. R. ed. The 1980 eruptions of Mount St. Helens, Washington. U.S. Geological Survey professional paper 1250: 577-600.

Sarna-Wojcicki, A. M.; Bowman, H. R.; Meyer, C. E.; Russell, P. C.; Woodward, M. J; McCoy, G.; Rowe, J. J. jun.; Baedecker, P. A.; Asaro, F.; Michael, H. 1984: Chemical analyses, correlations, and ages of Upper Pliocene and Pleistocene ash layers of east-central and southern California. U.S. Geólogical Survey professional paper $1293.40 \mathrm{p}$.

Smith, D. R.; Leeman, W. P. 1982: Mineralogy and phase chemistry of Mount St. Helens tephra sets W and
$\mathrm{Y}$ as keys to their identification. Quaternary research 17: 211-227.

Smith, D. G. W.; Westgate, J. A. 1969: Electron probe technique for characterising pyroclastic deposits. Earth and planetary science letters 5: 313-319.

Sparks, R. S. J.; Walker, G. P. L. 1977: The significance of virric-enriched air-fall ashes associated with crystal-enriched ignimbrites. Journal of volcanology and geothermal research 2: 329-341.

Sparks, R. S. J.; Brazier, S.; Huang, T. C.; Muerdter, D. 1983: Sedimentology of the Minoan deep-sea tephra layer in the Aegean and eastern Mediterranean. Marine geology 54: 131-167.

Spencer, K. J.; Lindsley, D. H. 1981: A solution model for co-existing iron-titanium oxides. American mineralogist 66: 1189-1201.

Stewart, R. B.; Neall, V. E. 1984: Chronology of paleoclimatic change at the end of the last glaciation. Nature 311: 47-48.

Storey, M. 1985: The petrology of volcanic rocks from Sao Miguel and Faial, Azores Islands. Unpublished Ph.D. thesis, lodged in the Library, University of London, London.

Taylor, N. H. 1933: Soil processes in volcanic ash beds. New Zealand journal of science and technology 14: 193-202, 338-352.

Thompson, R.; Bradshaw, R. H. W.; Whitley, J. E. 1986 : The distribution of ash in Icelandic lake sediments and the relative importance of mixing and erosion processes. Journal of Quaternary science 1:3-11.

Thorarinsson, S. 1981: The application of tephrochronology in Iceland. Pp. 109-134 in: Self, S.; Sparks, R. S. J. ed. Tephra studies. Dordrecht, D. Reidel.

Tonkin, P. J. 1967: Note on the occurrence of Taupo Pumice in the Hamilton Basin. Earth science journal 1: 31-32.

Topping, W. W. 1973: Tephrostratigraphy and chronology of late Quatemary eruptives from the Tongariro Volcanic Centre, New Zealand. New Zealand journal of geology and geophysics 16 : $397-423$.

Topping, W. W.; Kohn, B. P. 1973: Rhyolitic tephra marker beds in the Tongariro area, North Island, New Zealand. New Zealand journal of geology and geophysics 16: 375-395.

Vucetich, C. G. 1968: Soil-age relationships for New Zealand based on tephrochronology. Transactions 9th International Congress of Soil Science IV: 121-130.

Vucetich, C. G.; Pullar, W. A. 1964: Stratigraphy and chronology of late Quatemary volcanic ash in Taupo, Rotorua, and Gisbome districts. Part 2. New Zealand Geological Survey bulletin 73: 43-78.

1969: Stratigraphy and chronology of late Pleistocene volcanic ash beds in central North 
Island, New Zealand. New Zealand journal of geology and geophysics 12: 784-837.

1973: Holocene tephra formations erupted in the Taupo area, and interbedded tephras from other sources. New Zealand journal of geology and geophysics 16: 745-780

Walker, G.P. L. 1973: Explosive volcanic eruptions-a new classification scheme. Geologische Rundschau 62: 431-446.

1980: The Taupo Pumice: product of the most powerful known (ultraplinian) eruption? Journal of volcanology and geothermal research 8: 69-94.

1981 a: Generation and dispersal of fine ash and dust by volcanic eruptions. Journal of volcanology and geothermal research 11: 81-92.

1981b: The Waimihia and Hatepe plinian deposits from the rhyolitic Taupo Volcanic Centre. New Zealand journal of geology and geophysics 24: 305-324.

1981c: New Zealand case histories of pyroclastic studies. Pp. 317-330 in: Self, S.; Sparks, R. S. J. $e d$. Tephra studies. Dordrecht, D. Reidel.

Wallace, R. C.; Alloway, B. V.; Stewart, R. B.; Neall, V. E. 1986: Tephra mineral chemistry as an indicator of petrogenesis at Egmont volcano. Abstracts, International Volcanological Congress, Auckland-Hamilton-Rotorua. P. 23.

Watkins, N. D.; Sparks, R. S. J.; Sigurdsson, H.; Huang, T. C.; Federman, A.; Carey, S.; Ninkovich, D. 1978: Volume and extent of the Minoan tephra from Santorini: new evidence from deep-sea sediment cores. Nature 271: 121-126.

Westgate, J. A. 1977: Identification and significance of late Holocene tephra from Otter Creek, southern British Columbia, and localities in west-central Alberta. Canadian journal of earth sciences 14: 2593-2600.

Westgate, J. A.; Gorton, M. P. 1981: Correlation techniques in tephra studies. Pp. 73-94 in: Self, S.; Sparks, R.S.J.ed. Tephra studies. Dordrecht, D. Reidel.

Wilson, L.; Sparks, R. S. J.; Huang, T.C.; Watkins, N. D. 1978: The control of volcanic column heights by eruption energetics and dynamics. Journal of geophysical research 83: 1829-1836.

Wilson, C. J. N.; Houghton, B. F.; Lloyd, E. F. 1986: Volcanic history and evolution of the MaroaTaupo area, central North Island. Royal Society of New Zealand bulletin 23: 194-223. 